HYDROGEOLOGY IN THE ARBA OF A FRESHWATER LENS IN THE FLORIDAN AQUIFER SYSTEM, NORTHEAST SEMINOLE COUNTY, FLORIDA

By G. G. Phelps, U.S. Geological Survey, and K. P. Rohrer, St. Johns River Water Management District

U.S. GEOLOGICAL SURVEY

Water-Resources Investigations Report 86-4078

Prepared in cooperation with the

ST. JOHNS RIVER WATER MANAGEMENT DISTRICT

Tallahassee, Florida 


\section{UNITED STATES DEPARTMENT OF THE INTERIOR}

DONALD PAUL HODEL, Secretary

GEOLOGICAL SURVEY

Dallas L. Peck, Director

For additional information write to:

District Chief

U.S. Geological Survey

Suite 3015

227 North Bronough Street

Tallahassee, Florida 32301
Copies of this report can be purchased from:

U.S. Geological Survey Books and Open-File Reports Federal Center

Box 25425

Denver, Colorado 80225 


\section{CONTENTS}

Page

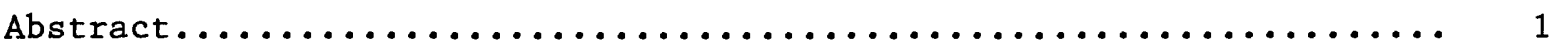

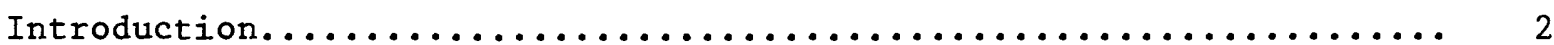

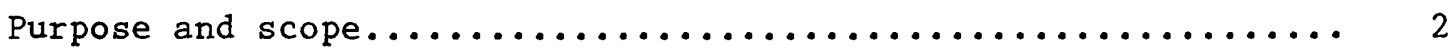

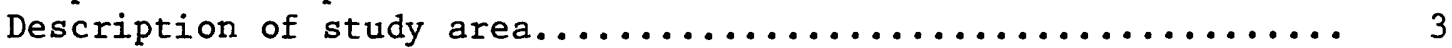

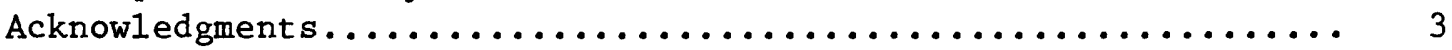

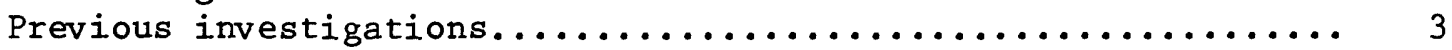

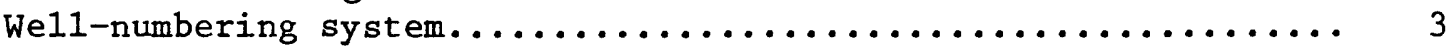

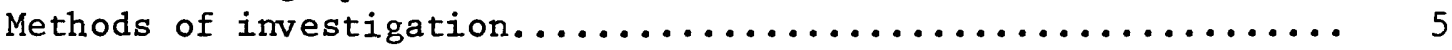

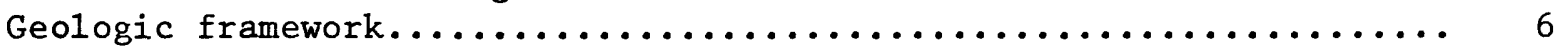

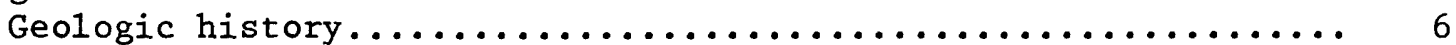

Description of geologic units...................... 8

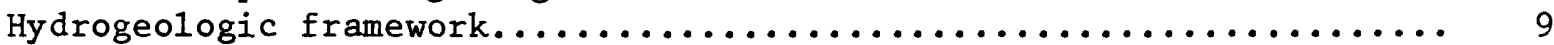

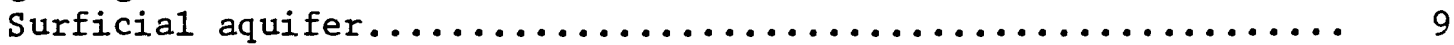

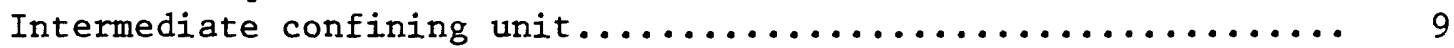

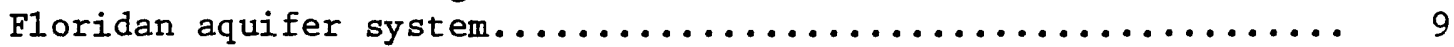

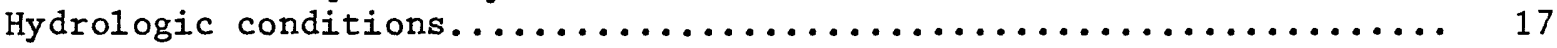

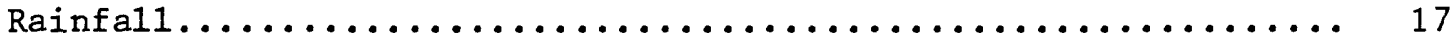

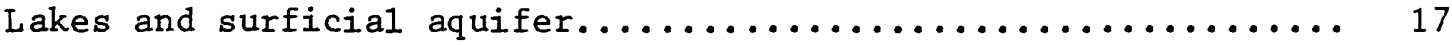

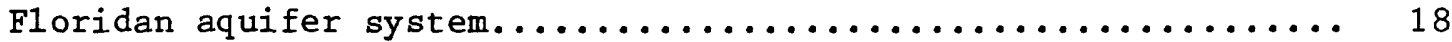

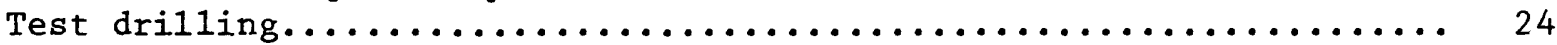

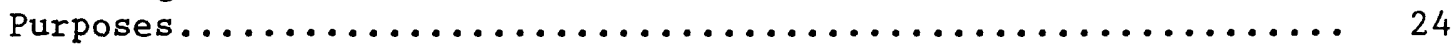

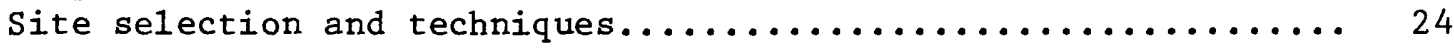

Holocene to Miocene deposits....................... 24

01 igocene and Eocene 1imestones..................... 39

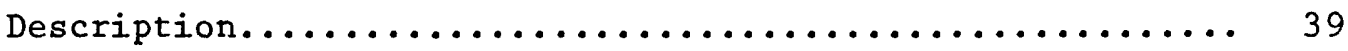

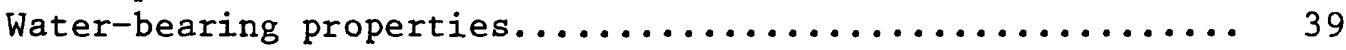

Chemical quality of water.................................. 41

Geochemical evidence of freshwater-saltwater mixing............. 54

Water budget.................................... 60

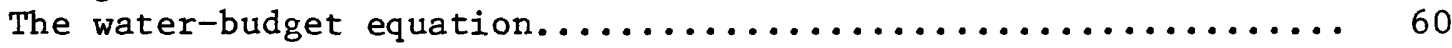

Estimating evapotranspiration....................... 61

Runoff and infiltration......................... 62

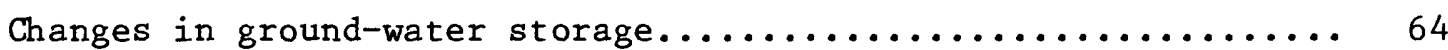

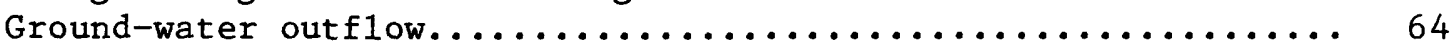

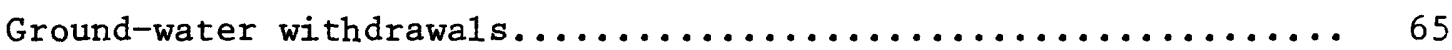

Limitations of the water budgets.................... 66

Conclusions based on the water budgets................. 66

Summary and conc1usions............................. 69

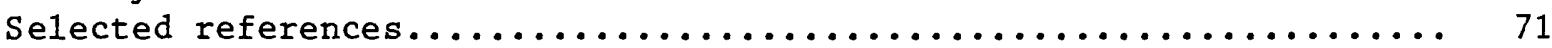




\section{ILL US TRAT IONS}

Page

Figure 1. Map showing location of study area, areas of artesian

flow of the Floridan aquifer system, and approximate

location of the $25-\mathrm{ft}$ topographic contour........... 4

2. Physiographic map of part of central florida.......... 7

3-6. Maps showing:

3. Recharge and discharge areas of central Florida and May 1981 potentiometric surface............ 10

4. Chloride concentration of water from the upper part of the Floridan aquifer system, 1951-54..... 11

5. Chloride concentration of water from the upper part of the Floridan aquifer system, 1973-74..... 12

6. Location of wells inventoried and sampled......... 14

7-8. Graphs showing:

7. Rainfall at Sanford, Florida, $1941-82 \ldots \ldots \ldots \ldots . \ldots . . .18$

8. Monthly rainfall at Lake Harney and Buck Lake, 1981-82.......................

9-11. Maps showing:

9. Potentiometric surface of the upper part of the Floridan aquifer system, January 1954 and $1956 \ldots$...

10. Potentiometric surface of the upper part of the Floridan aquifer system, September 1981 and 1982.. 23

11. Locations of test wells and geologic sections....... 25

12. Geologic and geophysical logs of test wells........... 26 13-15. Geologic sections:

13. $A-A^{\prime}$ and approximate location of freshwater-

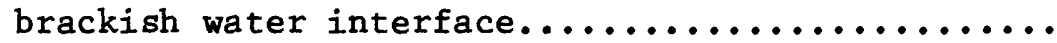

14. $B-B^{\prime}$ and approximate location of freshwaterbrackish water interface................ 37

15. $\mathrm{C}-\mathrm{C}^{\prime}$ and approximate location of freshwater-

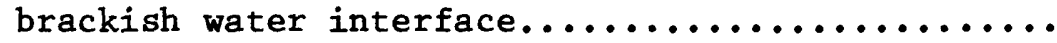

16-19. Maps showing:

16. Chloride concentration of water from the upper part of the Floridan aquifer system, November 1981-February 1982 (dry conditions).............

17. Chloride concentration of water from the upper part of the Floridan aquifer system,

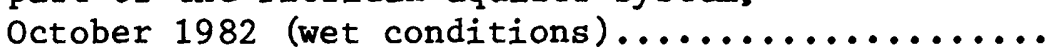

18. Sulfate concentration of water from the upper
part of the Floridan aquifer system, 1982..
19. Hardness of water from the surficial aquifer

18. Sulfate concentration of water from the upper
part of the Floridan aquifer system, 1982.......
19. Hardness of water from the surficial aquifer and upper part of the Floridan aquifer

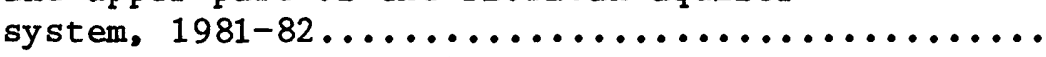

20. Piper diagram for water samples from northeast

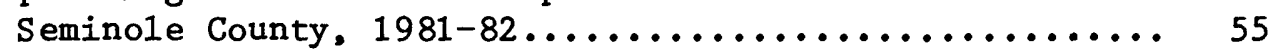

21. Locations of wells shown in figure $20 \ldots \ldots \ldots \ldots \ldots \ldots \ldots . \ldots . \ldots$

22. Dilution diagrams for water samples from the

Geneva area.............................. 


\section{TABL ES}

Page

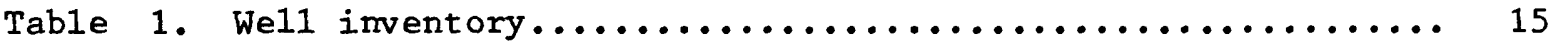

2. Elevation of Buck Lake near Geneva, $1981-83 \ldots \ldots \ldots \ldots \ldots \ldots .20$

3. Water levels in selected wells, 1982-83............... 21

4. Chemical analyses of water from wells in the Geneva area.. 42

5. Selected water-quality data for wel1 284428081072601

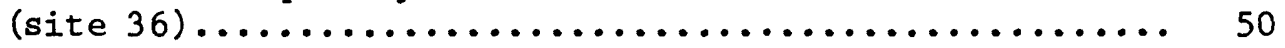

6. Examples of freshwater-saltwater mixing using the computer program PHREEQE and comparison to water samples from the Geneva area............... 57

7. Month1y potential evapotranspiration (PET) for the Geneva area for 1981, 1982, and thirty-year average climatic conditions using the modified BlaneyCriddle method............................. 63

8. Estimated pumpage in the Geneva area in $1981 \ldots \ldots \ldots \ldots \ldots \ldots 65$

9. Components of the water budgets for 1981, 1982, and thirty-year average conditions, in inches per year...... 


\title{
HYDROGEOLOGY IN THE AREA OF A FRESHWATER LENS IN THE FLORIDAN AQUIFER SYSTEM, NORTHEAST SEMINOLE COUNTY, FLORIDA
}

\author{
By G. G. Phelps and K. P. Rohrer
}

\begin{abstract}
Northeast Seminole County, Florida, contains an isolated recharge area of the Floridan aquifer system that forms a freshwater lens completely surrounded by saline water. The freshwater lens covers an area of about 22 square miles surrounding the town of Geneva, and generally is enclosed by the 25-foot land-surface altitude contour. Thickness of the lens is about 350 feet in the center of the recharge area. The hydrogeologic units in descending order consist of the post-Miocene sand and shell of the surficial aquifer; Miocene clay, sandy clay, and shell that form a leaky confining bed; and permeable Eocene 1imestones of the Floridan aquifer system. The freshuter lens is the result of local rainfall flushing ancient seawater from the Floridan aquifer system.
\end{abstract}

Sufficient quantities of water for domestic and small public-supply systems are available from the Floridan aquifer system in the Geneva area. The limiting factor for water supply in the area is the chemical quality of the water. Chloride concentrations range from less than 20 milligrams per liter in the center of the recharge area to about 5,100 milligrams per liter near the St. Johns River southeast of Geneva. Constituents analyzed included sulfate (range 1 to 800 milligrams per liter), hardness (range 89 to 2,076 milligrams per 1iter), and iron (range 34 to 6,600 micrograms per liter).

Because the freshwater lens results entirely from local recharge, the long-term sustained freshwater yield of the aquifer in the Geneva area depends on the local recharge rate. To estimate recharge, water budgets were calculated for 1981 and 1982, and for a long-term average using data from 1941 to 1970. It is estimated that recharge was about 5 inches ( 5.4 million gallons per day) in 1981, a year with much less than nomal rainfall. In 1982, recharge was about 13 inches (13.8 million gallons per day). Average recharge for 1941 through 1970 was estimated to be about 11 inches (11.3 million gallons per day). Freshwater that recharges the aquifer in the Geneva area is either pumped out or flows north and northeast to discharge near or in the St. Johns River. Average anmual outflow from the lens is about 10 inches per year. No measurable change in the size or location of the freshwater lens has occurred since studies in the early 1950's, probably because throughout most of that time, rates of pumpage from the aquifer have been very low and the disruption of the equilibrium between freshwater and saltwater has not resulted in detectable deterioration of water quality in the lens. If the freshwater outflow from the lens is reduced to less than 10 inches per year over the long term, deterioration of water quality will eventually occur. 


\section{INTRODUCTION}

The Floridan aquifer system in northeast Seminole County, Fla., contains an isolated recharge area that forms a freshwater lens surrounded by brackish water (chloride concentration greater than $250 \mathrm{mg} / \mathrm{L}$ ). Freshwater in the aquifer is derived from local precipitation falling on an area of comparatively high altitude centered around the town of Geneva, about 20 miles northeast of 0rlando. As the population of Florida has grown, so has the need for freshwater. Some of the most esthetically desirable locations for development along the coast and the St. Johns River have no freshwater available. For that reason, the demand for freshwater in areas such as the Geneva lens has increased, both for local development and for exportation to areas where the water is not potable.

Because all of the freshwater in the Geneva area comes from local recharge, estimates of the recharge rate are important to local government of ficials in planning water use in the area. Previous to this study, hydrologic data available for the Geneva area were not sufficient to determine accurately the rate of recharge and to locate precisely the transition between the freshwater and brackish water.

The U.S. Geological Survey, in cooperation with the St. Johns River Water Management District (which has the responsibility of permitting water use in eastcentral Florida) performed this study for the following purposes:

1. To describe the geohydrology and ground-water quality in the Geneva area;

2. To delineate the lateral and vertical extent of the freshwater lens; and

3. To estimate the recharge rate to the freshwater lens by evaluating the hydraulic characteristics of the Floridan aquifer system and overlying confining beds, and evaluating climatological data.

\section{Purpose and Scope}

This report describes the hydrogeology of the area containing the freshwater lens, estimates the recharge rate and provides data needed for water management decisions by the Water Management District and local government agencies. Information on ground-water recharge in this report may also be useful to hydrogeologic investigations of other areas of Florida.

This report does not attempt to provide a "safe yield" withdrawal rate for the Geneva area. Since the term "safe yield" was discussed by Todd (1959), there has been no agreement among hydrogeologists about how to quantify the concept. Clearly, the entire amount of water recharged to an aquifer is not available for use without creating adverse effects, but no simple means of calculating the "safe yield" exists. Mathematical modeling of chemical solutes such as the chloride ion shows promise in providing the answers, but first an understanding of the geohydrology of the area, the flow system, and the water chemistry are needed. The information from this study could provide background data for such future modeling studies. 


\section{Description of Study Area}

The study area comprises about $60 \mathrm{mi}^{2}$ surrounding the town of Geneva (fig. 1) in northeast Seminole County, Fla. The area is bounded on the north by the St. Johns River, on the south by the Econlockhatchee River and on the west and east by Lakes Jessup and Harney, respectively. The active recharge area is about $15 \mathrm{mi}^{2}$ in area, but because of regional ground-water flow patterns, the freshwater lens extend over an area of about $22 \mathrm{mi}^{2}$.

\section{Acknowledgments}

The authors wish to thank the property owners of Geneva for their cooperation in allowing access to their property for data collection and for test drilling. Thanks also, to the Seminole County Engineering Division for assistance in locating test drilling sites. Valuable assistance in preparation of lithologic and geologic logs from test well drill cuttings was given by J.A. Miller, hydrologist, U.S. Geological Survey, Atlanta, Ga. Geophysical logging was done by R. A. Johnson, St. Johns River Water Management District.

\section{Previous Investigations}

A general description of the ground-water resources of Seminole County was made by Stringfield (1934). In a later publication (Stringfield, 1936), information about Seminole County was included in a study of the water resources of the Florida Peninsula. Stubbs (1937) also reported on the ground-water hydro1ogy of Seminole County, with emphasis on the water supply for the city of Sanford. Data reports by Heath and Barraclough (1954), Barraclough (1962a), and an interpretive report by Barraclough (1962b) provided a reconnaissance of the ground-water resources of Seminole County. Tibbals (1977) studied the availability and quality of ground water in the county and delineated recharge and discharge areas. He also described the geohydrology of the Floridan aquifer system in east-central Florida (Tibbals, 1981). The scope of each of those reports was countywide or larger, restricting the amount of time and detail that could be devoted to study of the freshwater lens near Geneva.

\section{We11-Numbering System}

The U.S. Geological Survey assigns a unique site identification number to each well inventoried. The first 13 digits of the number denote the latitude and longitude of the well, and the last two digits denote a sequential number for wells located in the same 1-second latitude by 1-second 1ongitude block. For example, well 284233081045202 is the second well inventoried at latitude $28^{\circ} 42^{\prime} 33^{\prime \prime} \mathrm{N}$. and 1ongitude $81^{\circ} 04^{\prime} 52^{\prime \prime} \mathrm{W}$. Due to later revisions the site identification number may not be identical to the actual latitude-1ongitude location of the we11. 


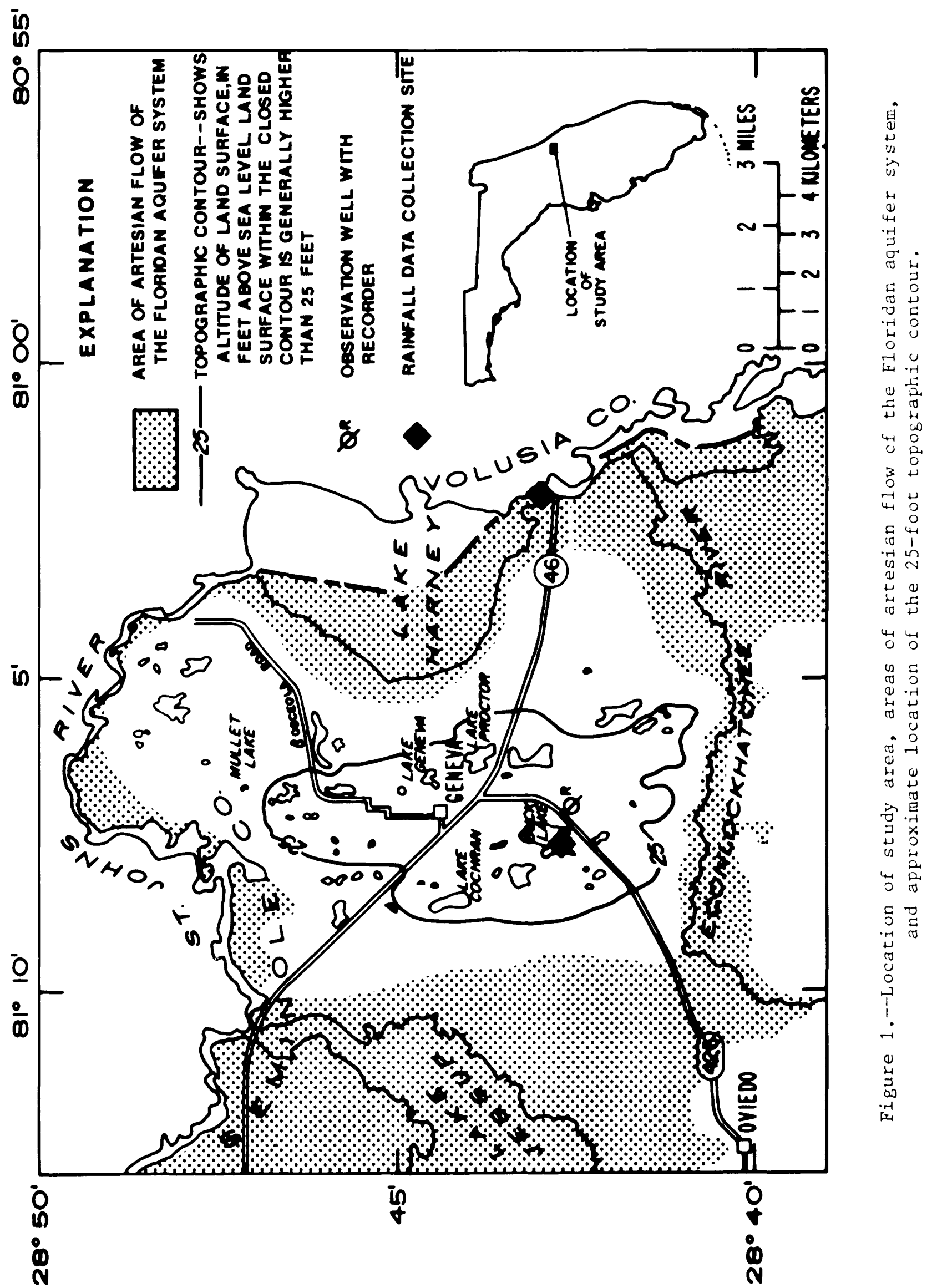




\section{Methods of Investigation}

Field work for the study done by the U.S. Geological Survey and the St. Johns River Water Management District included a wel1 inventory, quality of water sampling, and test drilling. Existing geologic and hydrologic data were compiled and evaluated. Well data collected by Tibbals (1977) in 1973 and 1974 were updated to provide a well inventory for the Geneva area. A water level recorder was installed on a well tapping the Floridan aquifer system, and a rain gage was also installed ( $f i g .1$ ). Water samples from more than 40 wells were collected and analyzed for major constituents. Test wells were drilled at 9 sites to determine hydraulic properties of the intermediate confining unit and the Floridan aquifer system, and to determine water-quality changes with depth. Specific capacity tests and geophysical logs were run in the test wells. Hydrologic properties of the soil types in the area were studied and used to estimate runoff from the recharge area. Rainfa11, water leve1, and runoff data were used to compute water budgets to estimate the amount of recharge available to the Floridan aquifer system under existing conditions. 


\section{GEOL OGIC FRAMEWORR}

\section{Geologic History}

The Florida Peninsula is composed of a thick sequence of marine limestone and dolomite deposited over a period of about 100 million years (m.y.) during the Cretaceous and Tertiary geologic time periods. Regional submergence of most of the southeastern United States and deposition of marine sediments occurred throughout the Cretaceous Period (about 138 to 63 m.y. ago). A regression of sea leve1, evidenced in the geologic record by a break in deposition of sediments (an unconformity) occurred at the end of the Cretaceous Period. Then throughout most of the Paleocene and Eocene Epochs of the Tertiary Period (from about 63 to $38 \mathrm{~m} . y$. ago), the Florida Peninsula was a relatively shallow (water depth about $150 \mathrm{ft}$ ) carbonate reef (Chen, 1965, p. 5). Then in the 01igocene and Miocene Epochs (about 38 to $5 \mathrm{m.y}$. ago), the deposition across much of the Florida Peninsula of land-derived clastic sediments, as opposed to marine carbonate sediments, indicates gradual marine regression.

Many of the topographic features of Florida are believed to be relict shoreline features formed when the sea fell, then rose in response to the advances and retreats of Pleistocene glaciation within the 1ast 2 m.y. (MacNei1, 1950). Some recent workers (Opdyke and others, 1984) suggest that isostatic uplift of the Florida Peninsula because of the dissolution of limestone, rather than changes in sea level, is the mechanism of relict shoreline formation. White (1970, p. 114) traced a series of beach ridges which includes Geneva Hill (fig. 2) in northeast Seminole County from the Orange-Seminole County line northward to Palatka Hill. He believes this ridge was part of the Wicomico shoreline formed during the Sangamon interglaciation (about 100,000 years ago) when the sea level was about 100 feet higher than present. The Pamlico shoreline, about 25 feet above present sea leve1, formed during the mid-Wisconsin glacial recession (about 40,000 years ago). During late Wisconsin glaciation (which ended about 10,000 years ago) sea level fell again. Areas inundated by the Wicomico and Pamlico seas were exposed again to erosion, and sediments which were saturated by seawater at the time of deposition and again by subsequent sea transgressions began to be flushed by freshwater from local rainfall. It is significant that land surfaces less than 25 feet in altitude were the most recently inundated by the sea; in northeast Seminole County, fresh ground water is found in both surficial and Floridan aquifer systems where the land surface altitude is greater than 25 feet, but where altitudes are 1ower than 25 feet, most ground water is brackish.

The other major influence on the landforms of the study area is the process of karst formation. Karst results when limestone is dissolved by water. The 1imestone usually dissolves more rapidly in some areas than in others, resulting in an irregular land surface. Features of karst include lack of surface drainage, the presence of sinks, springs, and round lakes (caused by the coalesing of sinkholes), and a wide variation in the altitude of contemporaneous relict shoreline features such as the Wicomico shoreline (White, 1970, p. 123-124).

As a result of the combined processes of karst development on a limestone terrain and the deposition of a series of beach ridges, the topography of the recharge area is characterized by rolling sand hills ranging in altitude from 25 to 80 feet surrounded by a marshy low-1ying area with altitudes that range from 5 to 20 feet. 


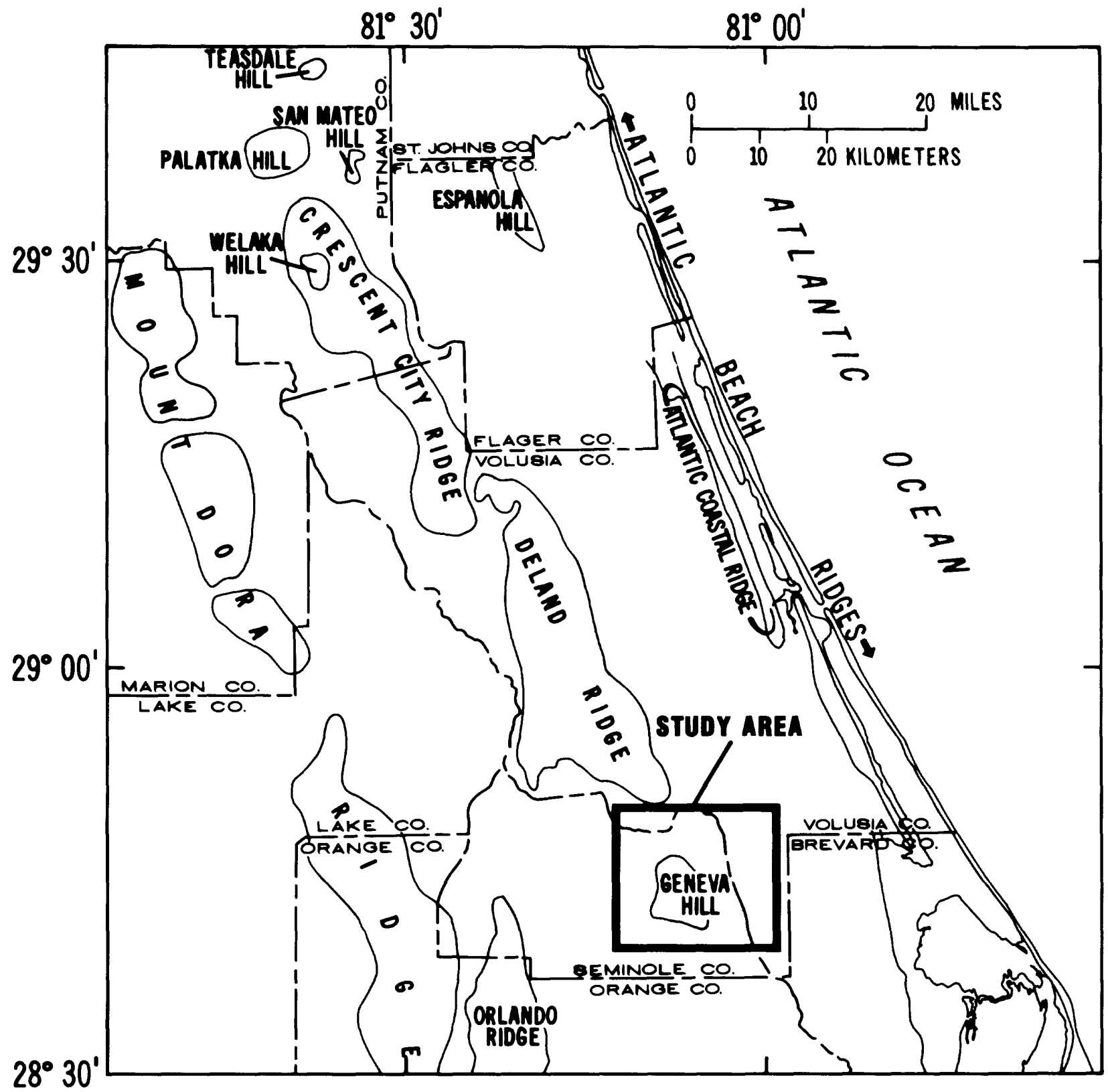

Figure 2.--Physiographic map of part of central Florida (modified from White, 1970, plate 1B). 


\section{Description of Geologic Units}

The surficial deposits range in thickness from 10 to 70 feet. They consist of post-Miocene age (undifferentiated Pliocene to Holocene) deposits composed mostly of sand or sandy clay. In some low-lying areas surrounding Geneva, the surficial deposits are predominantly silt and clay.

Underlying the surficial deposits are about a 20 to 60 foot thickness of Miocene deposits--either the middle Miocene Hawthorn Formation or undifferentiated upper Miocene deposits. These deposits are predominantly shell and clayey sand with some sandy phosphatic limestone.

Limestones of Eocene to Oligocene age underlie the Miocene sediments and are found at depths ranging from 50 to about 120 feet below land surface. In descending order they consist of: occasional erosional remnants of the Suwannee Limestone of O1igocene age; the Ocala Limestone (10 to nearly 200 feet thick) and the Avon Park Formation, both of Eocene age. The base of the Avon Park has not been penetrated in the study area, but Chen (1965, fig. 10) estimated the formation to extend to a depth of about 1,500 feet below sea level in central Florida.

A more detailed discussion of the geology is given in the "Test Drilling" section of this report. 


\section{HYDROGEOL OGIC FRAMBWORK}

\section{Surficial Aquifer}

The surficial aquifer, consisting of post-Miocene sediments, contains the water table. Water levels in the surficial aquifer are generally within 10 feet of land surface but can be as much as 20 feet below land surface on hilltops. Water levels usually increase in altitude rapidly in response to rainfall. In places, the surficial aquifer contains shell beds under confined conditions because of less permeable overlying sediments. In the Geneva area, limited use is made of the surficial aquifer for domestic supply and lawn or garden irrigation.

\section{Intermediate Confining Unit}

Miocene sediments form a confining layer between the surficial aquifer and the underlying Floridan aquifer system. Leakage through the confining layer is determined by the amount of clay present in the Miocene sediments and their thickness. On the topographic high area centered around Geneva the sediments are sandy and the confining beds are thus leaky. In the surrounding areas of low topography, clay layers as thick as 20 feet form a competent confining layer.

\section{F1oridan Aquifer System}

The main source of water in the Geneva area is the Floridan aquifer system, which consists of permeable limestone and dolomite beds of Eocene to 01igocene age. Regional flow of water in the aquifer is generally northeastward from recharge areas in western Orange and Seminole Counties to discharge areas along the St. Johns River (fig. 3 ).

In the Geneva area, a local flow system that overlies the regional flow system has resulted in a freshwater lens surrounded by brackish water. A downward hydraulic gradient from the surficial aquifer to the Floridan aquifer system and the absence of thick clay layers have allowed local freshwater recharge to flush saltwater out of the sediments. The Geneva freshwater lens was first noted in the literature by Stringfield (1936, plate 16). The areal extent of the freshwater lens was first mapped by Barraclough in 1952-54 (1962b, fig. 36) and is shown in figure 4. In 1973-74, Tibbals (1977) refined the delineation of the lens and found 1ittle change from Barraclough's measurements (fig. 5).

Transmissivity estimates for the upper part of the Floridan aquifer system in the study area range from 1,700 to $17,000 \mathrm{ft} / \mathrm{d}$ (Tibbals, 1977, fig. 14) based on aquifer test analyses, and from 35,000 to $100,000 \mathrm{ft}^{2} / \mathrm{d}$ based on computer model simulation (Tibbals, 1981, fig. 6). The higher values derived from model simulation are thought to reflect the transmissivity of the full thickness of the upper part of the aquifer. The study area is located in a region of relatively low transmissivity that extends from the east coast of Florida to about the St. Johns River (Tibbals, 1981, fig. 6). Because of the relatively low transmissivity, flow through the Floridan in the region is generally slow-moving. 

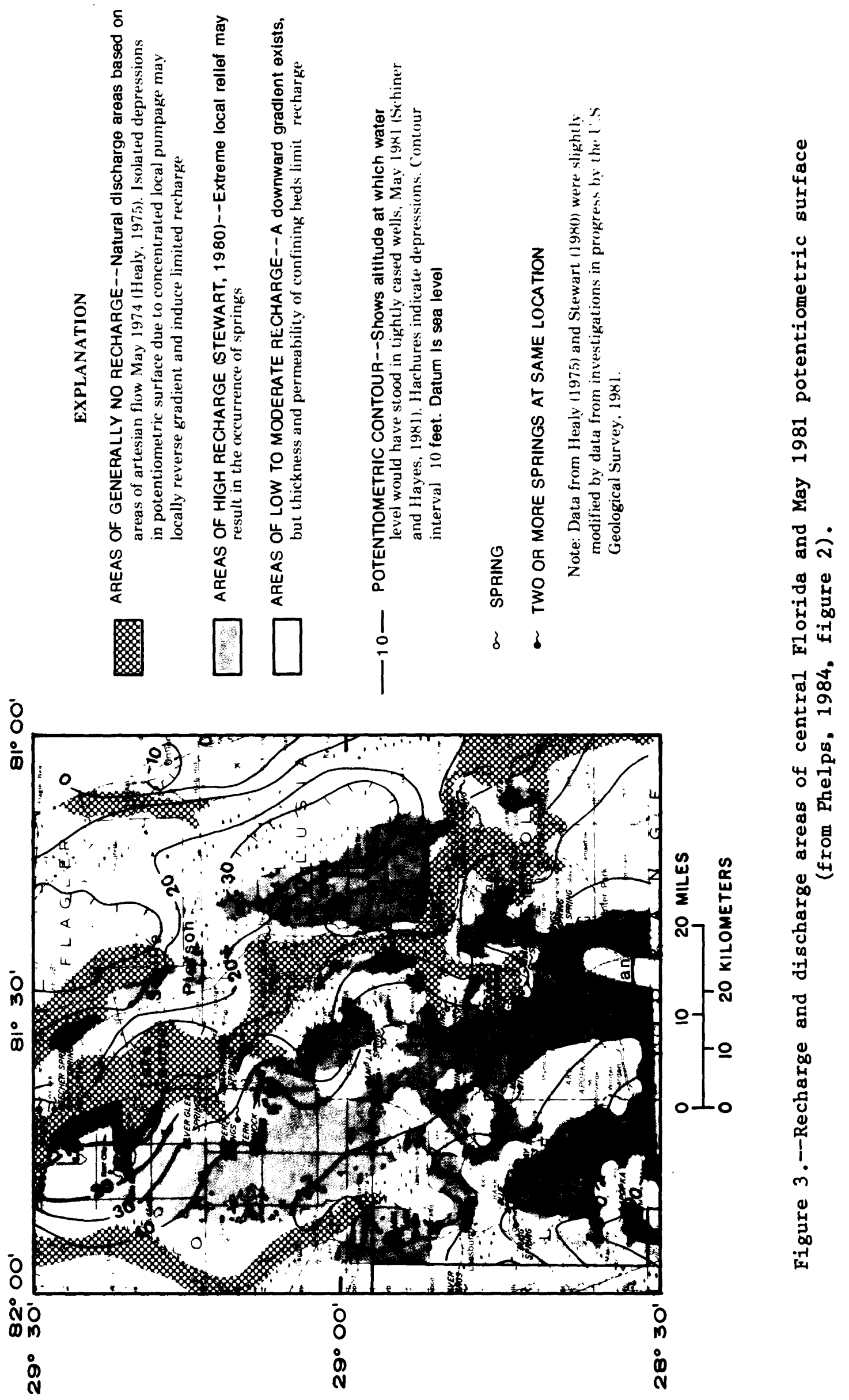


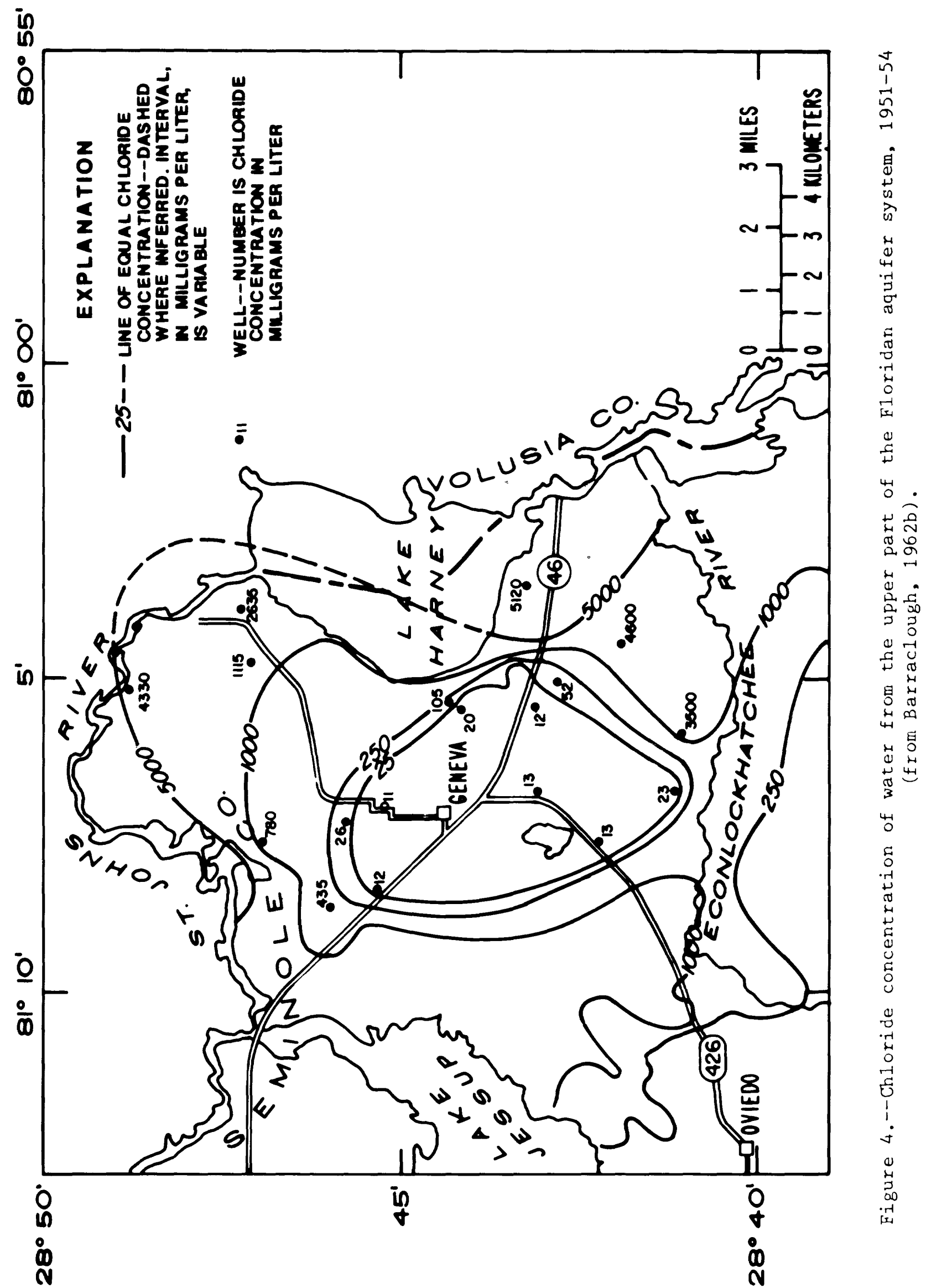


in

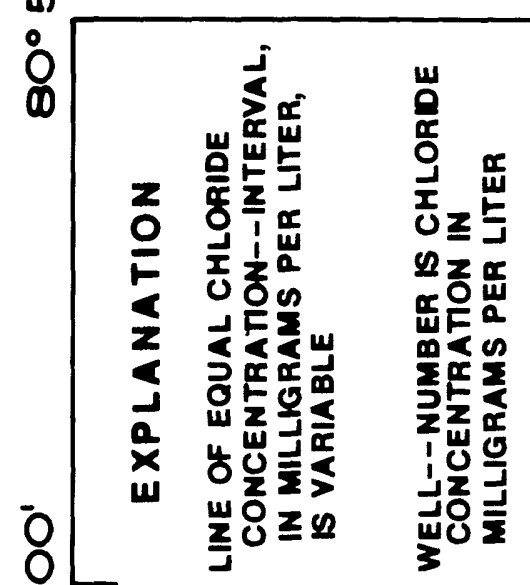

$\frac{0}{10}$

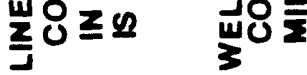

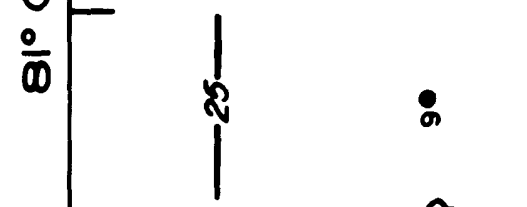

in

in
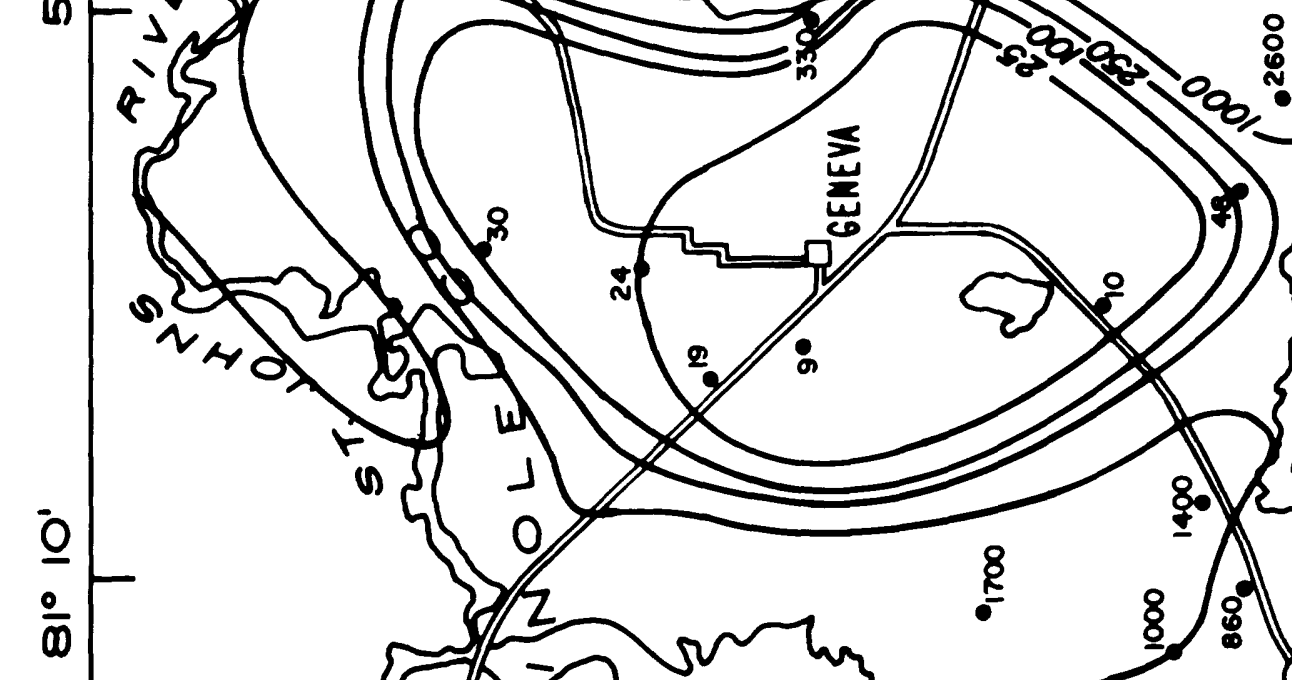

.

$x$
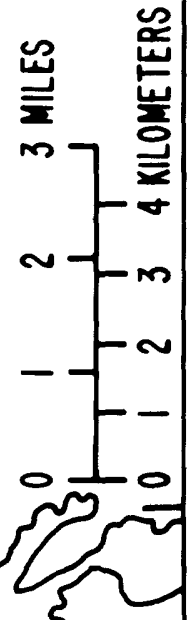

1

40

$\stackrel{4}{4}$

政

-

中

م.

先

단?

皇

$\boldsymbol{\omega}$
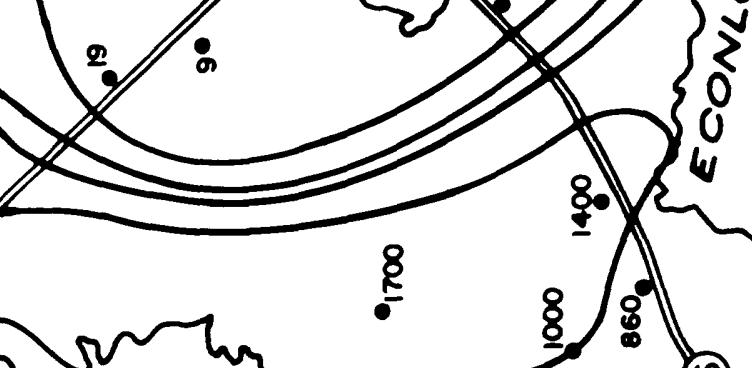

ט

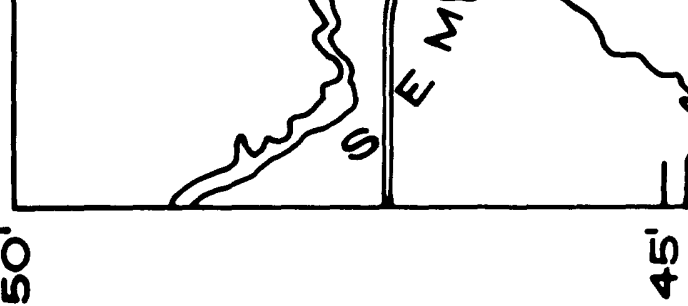


It is estimated that as many as 100 wells tap the Floridan aquifer system in the study area. The population of the area is growing and new wells are being drilled 1iterally every day. Most of the wells are used for domestic supply for one or two families. Also, there are two municipal supply wells and six or seven irrigation wells. The well inventory prepared for this study concentrated mainly on wells in the transition zone between freshwater and brackish water. Wells inventoried for this study are shown in figure 6 and described in table 1. 


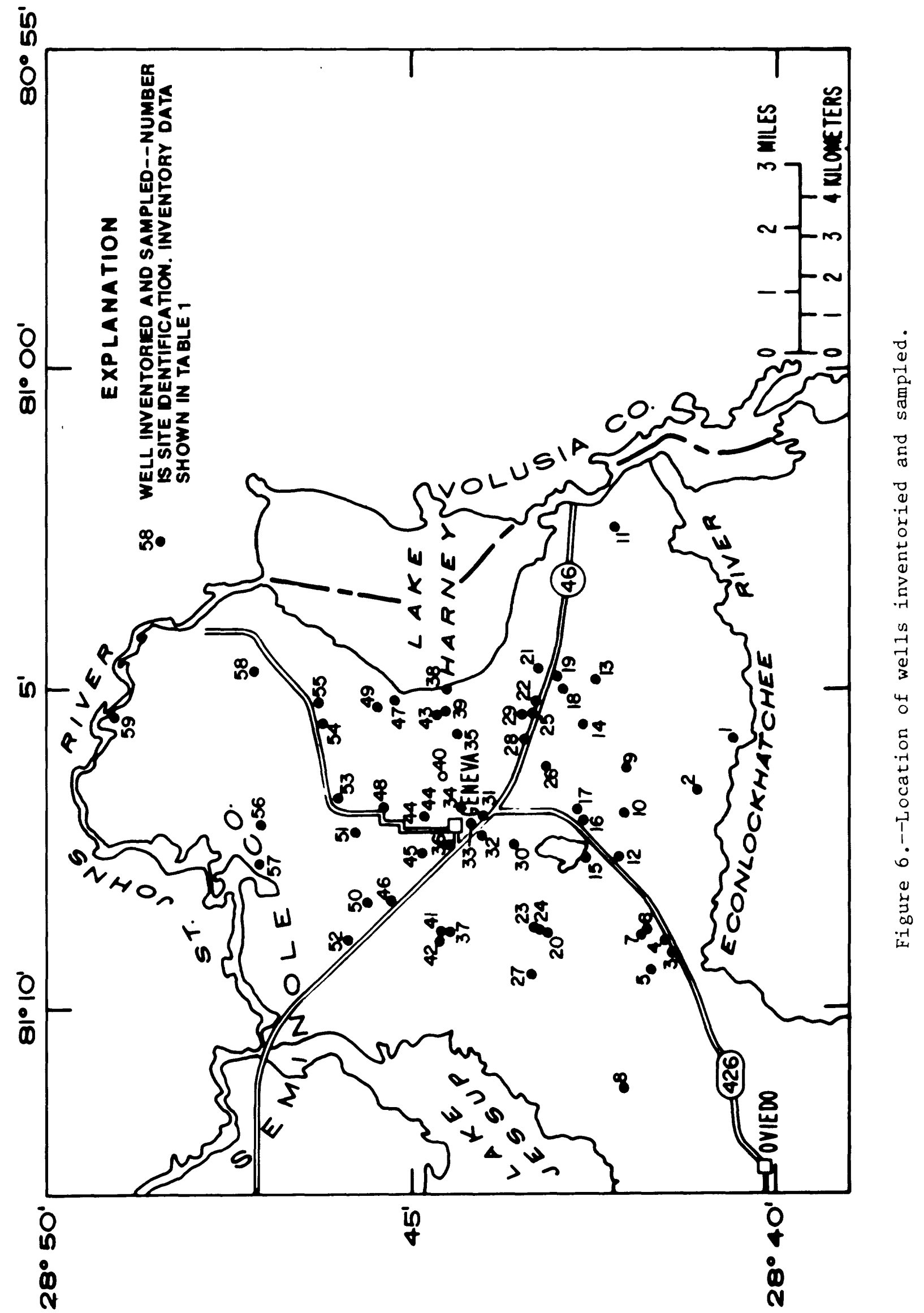


Tab1e 1.--We11 inventory

\begin{tabular}{|c|c|c|c|c|c|c|c|c|}
\hline \multirow[b]{2}{*}{$\begin{array}{l}\text { Site } \\
\text { No. }\end{array}$} & \multirow{2}{*}{$\begin{array}{c}\text { Site } \\
\text { identification } \\
\text { No. }\end{array}$} & \multirow[b]{2}{*}{ Name } & \multirow{2}{*}{$\begin{array}{l}\text { Well } \\
\text { depth } \\
\text { (ft) }\end{array}$} & \multicolumn{2}{|c|}{ Casing } & \multirow[b]{2}{*}{ Use of water } & \multirow{2}{*}{$\begin{array}{l}\text { Land } \\
\text { surface } \\
\text { altitude } \\
\text { (ft) }\end{array}$} & \multirow{2}{*}{$\begin{array}{c}\text { Aquifer } \\
\text { or } \\
\text { unit }\end{array}$} \\
\hline & & & & $\begin{array}{l}\text { Depth } \\
\text { (ft) }\end{array}$ & $\begin{array}{c}\text { Diameter } \\
\text { (in.) }\end{array}$ & & & \\
\hline 1 & 284043081054401 & Yarborough Hunt & 78 & -- & 2 & Unused & 26 & Floridan \\
\hline 2 & 284111081063401 & Yarborough Sect 3 & 90 & -- & 2 & Stock & 25 & Do. \\
\hline 3 & 284127081090501 & Patterson & -- & -- & 3 & Domestic & 28 & Do. \\
\hline 4 & 284133081085501 & McNair & 230 & -- & 4 & do. & 28 & Do. \\
\hline 5 & 284146081092201 & Norman & 90 & -- & 2 & do. & 25 & Do. \\
\hline 6 & 284150081084601 & Col eman Deep & 160 & 124 & 4 & Unused & 29 & Do. \\
\hline 7 & 284152081084801 & Coleman Shallow & 55 & -- & 4 & Domestic & 30 & Surficial \\
\hline 8 & 284207081111601 & Soistman & 205 & 76 & 4 & Test & 8.40 & Floridan \\
\hline 9 & 284208081061301 & Yarborough Snd & 200 & -- & 10 & Irrigation & 25 & Do. \\
\hline 10 & 284210081065601 & Snow Hill & -- & -- & 2 & Domestic & 42 & Do. \\
\hline 11 & 284217081023001 & Kil1bee \#3 & 154 & 58 & 4 & Test & 11.76 & Do. \\
\hline 12 & 284219081074001 & Ladd & 101 & -- & 2 & Domestic & 32 & F1oridan? \\
\hline 13 & 284233081045201 & Kil1bee \#1 & 100 & 77 & 4 & Test & 16.95 & Floridan \\
\hline 13 & 284233081045202 & Killbee \#2 & 140 & 107 & 4 & do. & 16.95 & Confining be \\
\hline 14 & 284243081053301 & Killbee Ranch & 110 & -- & 2 & Stock & 27 & Surficial? \\
\hline 15 & 284244081073501 & Farmer & 200 & -- & 4 & Domestic & 29.10 & Floridan \\
\hline 16 & 284247081070601 & Pellarin & 188 & -- & 4 & do. & 52 & Do. \\
\hline 17 & 284247081070801 & Pellarin Test & 204 & 95 & 4 & Test & 49.07 & Do. \\
\hline 17 & 284247081070802 & do. & 50 & 50 & 2 & do. & 49.07 & Surficial \\
\hline 18 & 284300081045801 & Conley & 71 & 65 & 3 & Domestic & 16.27 & Floridan? \\
\hline 19 & 284312081045101 & Jepson Store & 70 & -- & 2 & do. & 19 & Floridan \\
\hline 20 & 284312081084401 & Fagan & 126 & -- & 4 & do. & 45 & Do. \\
\hline 21 & 284319081044301 & Cammack & 94 & 58 & 3 & Stock & 17 & Do. \\
\hline 22 & 284320081051201 & Wilson & -- & -- & 2 & Domestic & 22 & Do. \\
\hline 23 & 284322081084301 & Cockran For. East & 203 & 90 & 4 & Test & 44.52 & Do. \\
\hline 24 & 284322081084401 & Davidson & -- & -- & 4 & Domestic & 45 & Surficial \\
\hline 25 & 284325081052401 & Hillside \#1 & 120 & -- & 4 & Irrigation & 33 & Floridan \\
\hline 26 & 284325081061201 & Jepson Home & 128 & -- & 2 & Domestic & 30 & Do. \\
\hline 27 & 284325081092701 & Cockran For. West & 165 & 56 & 4 & Test & 18.26 & Do. \\
\hline 27 & 284233081045201 & Cockran For. W. Shal. & 37 & 37 & 2 & do. & 18.26 & Surficial \\
\hline
\end{tabular}


Table 1.--We11 inventory--Continued

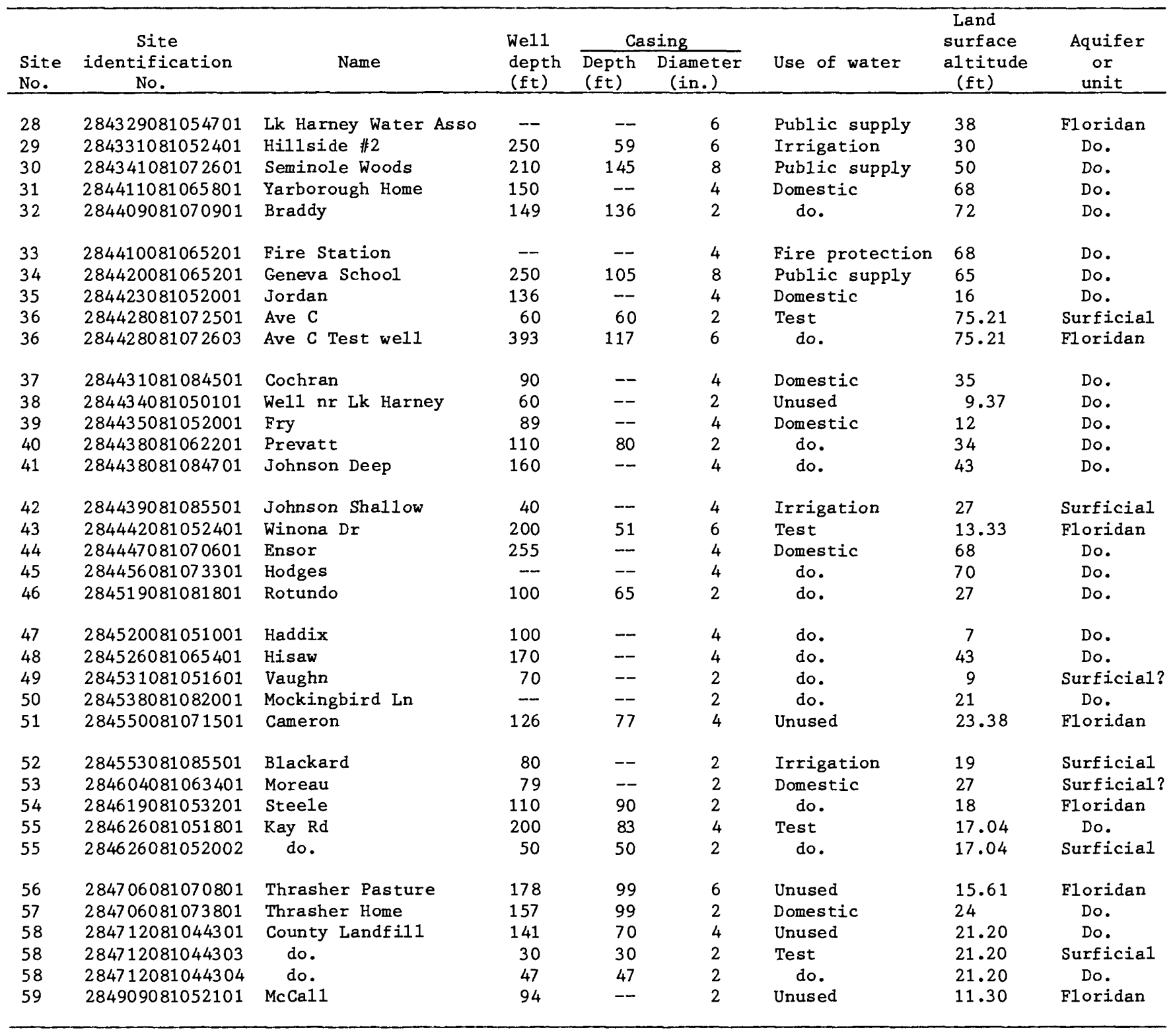




\title{
HYDROL OGIC CONDITIONS
}

\author{
$\underline{\text { Rainfa11 }}$
}

During the study, a drier than average year (1981) was followed by a wetter than average year (1982), which allowed data collection during both types of conditions and an evaluation of the response of the hydrologic system to a range of climatic conditions. The 30-year average rainfall computed by the National Oceanic and Atmospheric Administration for 1941 to 1970 at Sanford (12 miles northwest of Geneva) is 53.32 inches (fig. 7). The average rainfall at Sanford for the entire period of record (1913-82) is 51.33 inches. Rainfall in Sanford in 1981 was 41.67 inches and in 1982, 59.91 inches.

Rainfall at a gage on Lake Harney (about 3 miles east of Geneva) for 1981 and 1982 (fig. 8) was 41.84 and 73.06 inches, respectively. The difference between 1982 rainfall at Sanford and Lake Harney is due to the widely scattered nature of convection thunderstorms that commonly occur in Florida.

A recording tipping bucket rain gage was established at Buck Lake in July 1981 and data were collected until June 1982. Data from the Buck Lake rain gage are shown in figure 8.

\section{Lakes and Surficial Aquifer}

Several shallow lakes in the Geneva area store rainfall that then percolates downward through the surficial aquifer to the Floridan aquifer system. Some lakes, such as Lake Cochran (fig. 1), contain water only during the wettest months of wet years and at other times are swamps or are dry beds. The two halves of Lake Proctor (fig. 1) once formed a single lake, but the lake stage has been lowered through time and the lake is now bisected by State Road 46.

Lake Geneva had the largest stage fluctuation of the five lakes in Seminole County monitored by Barraclough during 1953-56 (1962b, p. 40). The lake's stage ranged about 7 feet (21.5 to 28.2 feet in altitude). During 1953-56, the lake level was 2 to 6 feet higher than water levels in nearby wells in the Floridan aquifer system. Periodic measurements of the stage levels in Lake Geneva were discontinued in 1979. In March 1981, a staff gage on the lake was out of the water (stage was less than 20.86 feet above sea leve1). The lake became two shallow ponds because the center of the lake was dry. By May 1981, the eastern part of the lake (where the staff gage is located) was completely dry. It remained dry until the end of the summer of 1982 when above average rainfall refilled the lake. On October 14, 1982, the lake stage was 23.05 feet above sea leve1.

A staff gage was installed on Buck Lake (fig. 1), a major lake in the Geneva area, in April 1981. Within a month, the lake level had dropped so that the gage was out of the water. Stage levels of Buck Lake are shown in table 2. Although the minimum stage reached during the drought of 1981 is not known, the fluctuation from 1981 to 1982 was at least 3 feet. From September 1981 to September 1982 the potentiometric surface of the Floridan aquifer system in the area fluctuated about 3 feet and was lower than the lake level. None of the lakes in the Geneva area appear to be directly connected to the Floridan. 


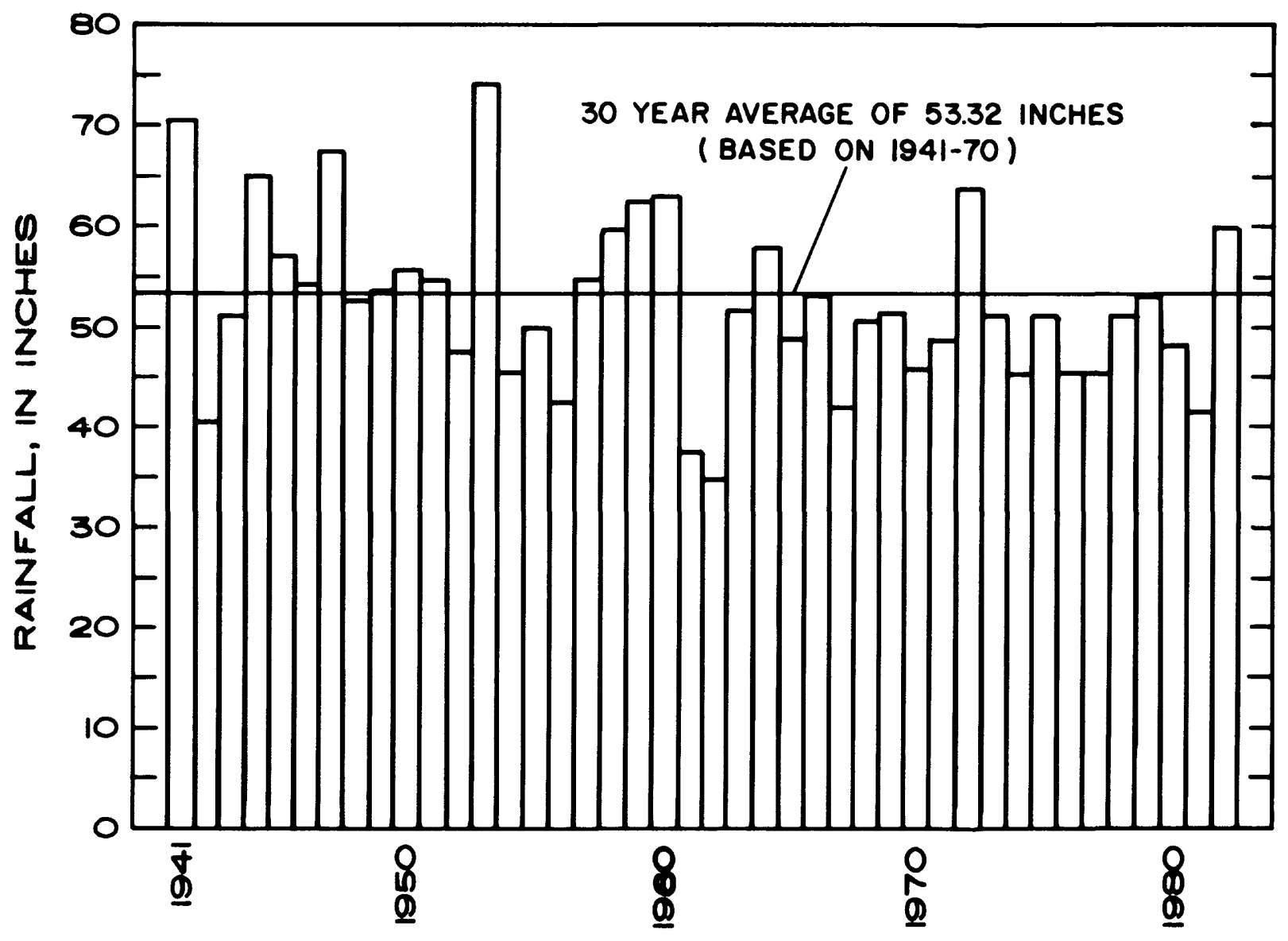

Figure 7.--Rainfal1 at Sanford, Florida, 1941-82 (data from National Oceanic and Atmospheric Administration climatological station at Sanford).

Water levels in several existing wells and five test wells in the surficial aquifer were measured during the study. Water-level data are shown in table 3. The maximum fluctuation was about $2-1 / 2$ feet. Because most of the test we11s were drilled after the drought period the minimum levels that occurred during the dry year (1981) were not documented. Depth to water in the surficial aquifer wells ranged from $1-1 / 2$ feet at site 27 (1and surface altitude 18.26 feet) to $20-1 / 2$ to 24 feet at site 36 (land surface altitude 74.21 feet).

\section{Floridan Aquifer System}

Potentiometric surface maps of the Floridan aquifer system in Seminole County were compiled by Barraclough (1962b, figs. 7 and 8) for January 1954 (following a wet year in 1953) and January 1956 (following a dry year in 1955) and are shown in figure 9. Figure 10 shows potentiometric surface maps for September 1981 (dry year) and September 1982 (wet year) compiled by Schiner and Hayes (1981 and 1982). A comparison between these maps shows almost identical potentiometric surfaces, suggesting no long-term decline in the potentiometric surface in the Geneva area. 
MONTHLY RAINFALL AT LAKE HARNEY NEAR STATE ROAD 46

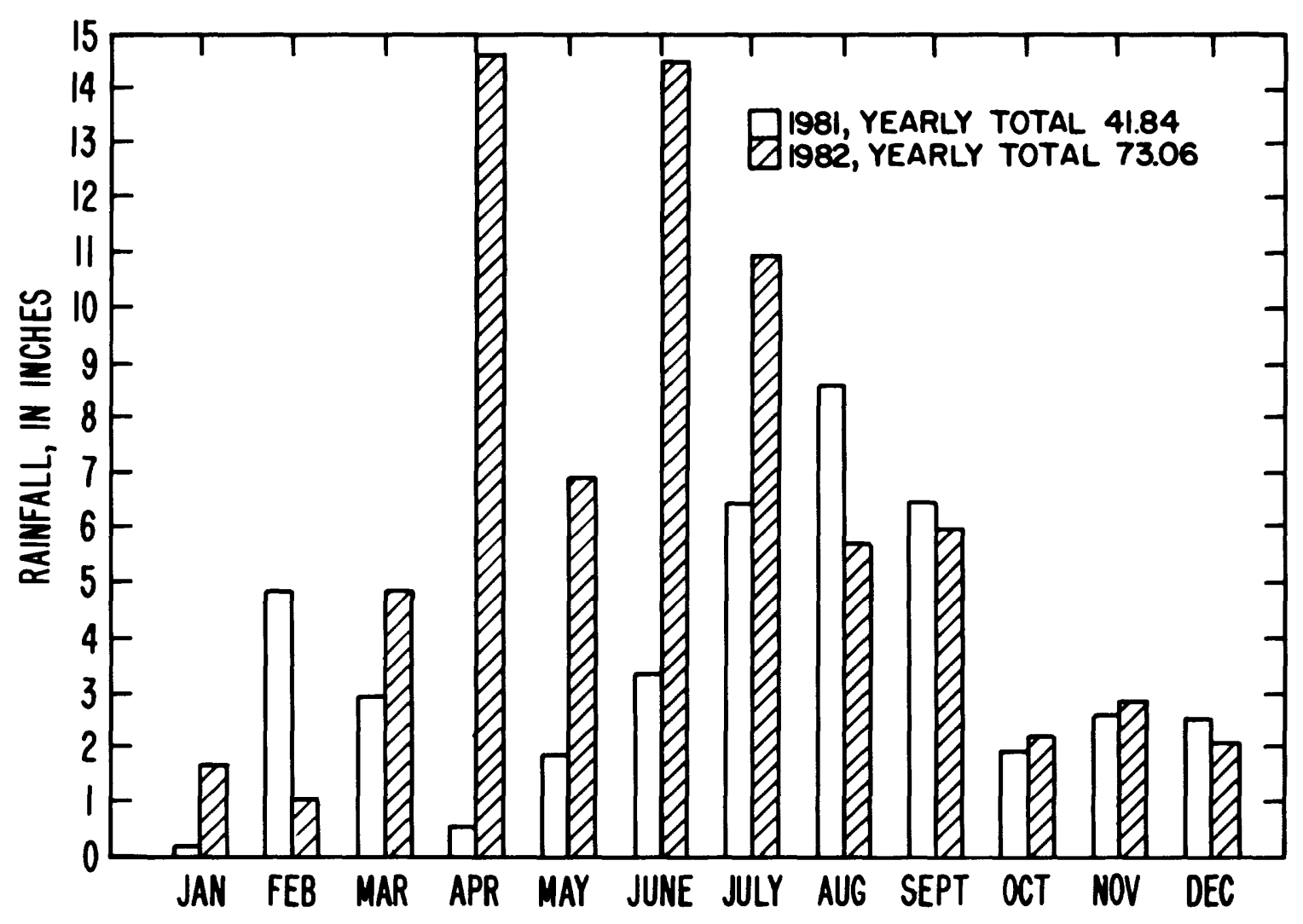

MONTHLY RAINFALL AT BUCK LAKE

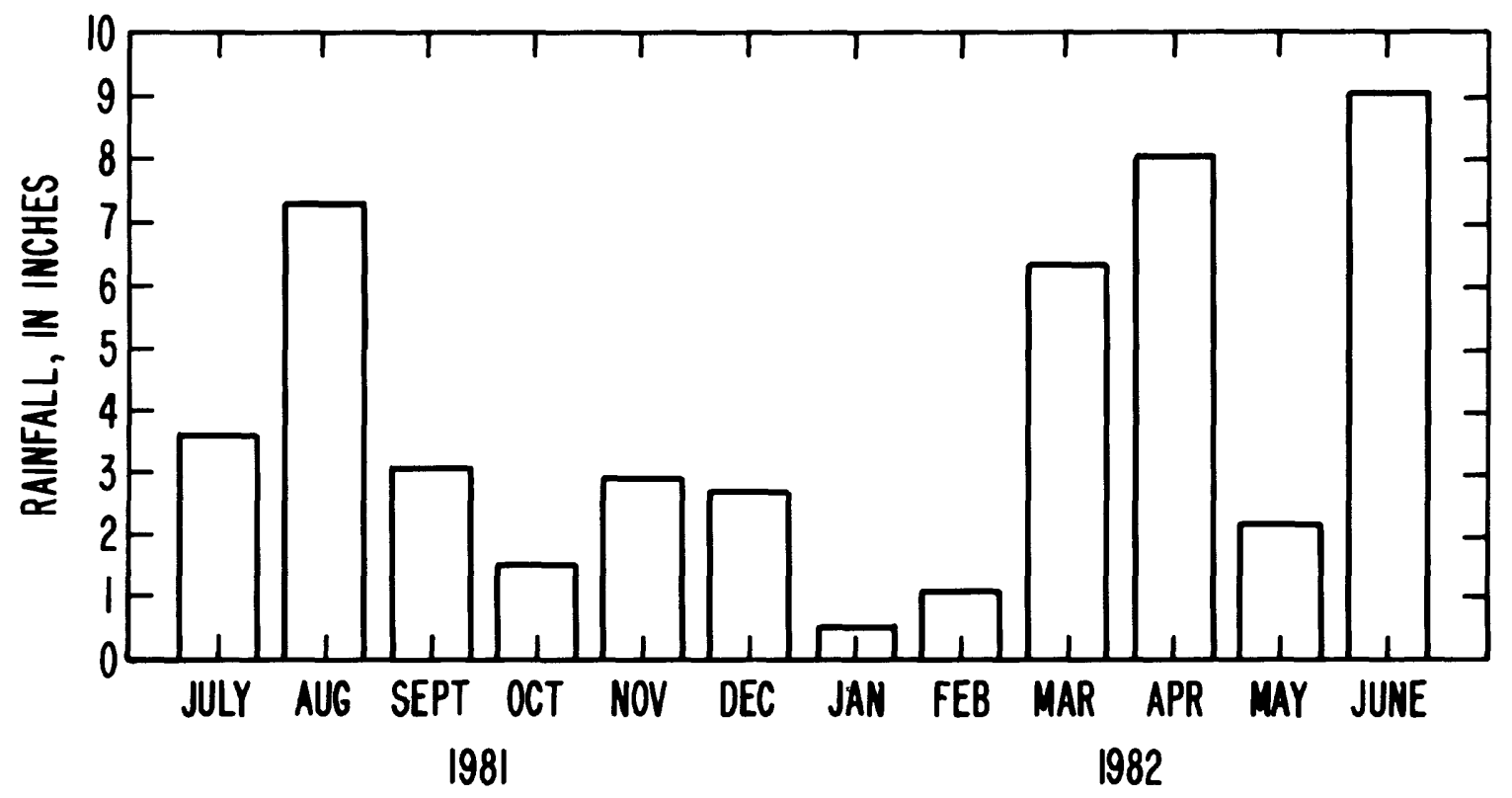

Figure 8.--Month1y rainfal1 at Lake Harney and Buck Lake, 1981-82. 
Table 2.--Elevation of Buck Lake near Geneva, 1981-83

\begin{tabular}{cc}
\hline Date & E1evation \\
\hline $04-14-81$ & 23.52 \\
$05-19-81$ & 22.80 \\
$06-04-81$ & 22.62 \\
$06-17-81$ & 1 ess than 22.60 (gage out of water) \\
$09-14-81$ & do. \\
$04-12-82$ & do. \\
$05-12-82$ & do. \\
$06-15-82$ & 22.90 \\
$07-06-82$ & 23.45 \\
$08-12-82$ & 23.64 \\
$10-14-82$ & 25.46 \\
$12-07-82$ & 25.32 \\
$01-12-83$ & 25.30 \\
$03-03-83$ & 26.50 \\
\hline
\end{tabular}

Table 3 shows water levels during 1982-83 for several wells tapping the Floridan aquifer system. A water-level recorder was installed on the test we11 at site 17. The minimum water 1 evel measured was 16.86 feet above sea 1 evel in January 1982, and the maximum was 20.17 feet above sea level in September 1982 , a range of 3.31 feet.

The Geneva freshwater lens is a result of local recharge that percolates downward from the surficial equifer to the Floridan. Recharge occurs when water levels in the surficial aquifer are higher than the water levels in the Floridan (a downward gradient exists). The area enclosed by the 25-foot altitude contour (fig. 1) is where most of the recharge occurs. For example, water levels of wells in the surficial aquifer and Floridan aquifer system (table 2) indicate a downward gradient at sites 17 and 36 . The gradient is also downward at sites 20 , 23, and 24, based on measured water levels and pump types at those sites. In some areas of lower topography the gradient is upward (discharge areas) whereas in other areas the gradient is downward, but the head difference between the surficial aquifer and Floridan aquifer system is slight and little recharge takes place. At site 55, the vertical hydraulic gradient changes direction seasona11y-upward during the dry season and downward during the wet season.

The water level or head difference between the two aquifers is not the only factor controlling recharge. Other important factors are hydraulic conductivity and thickness of the intermediate confining unit. The confining unit must be thin and permeable enough to allow appreciable recharge to the upper part of the Floridan. 


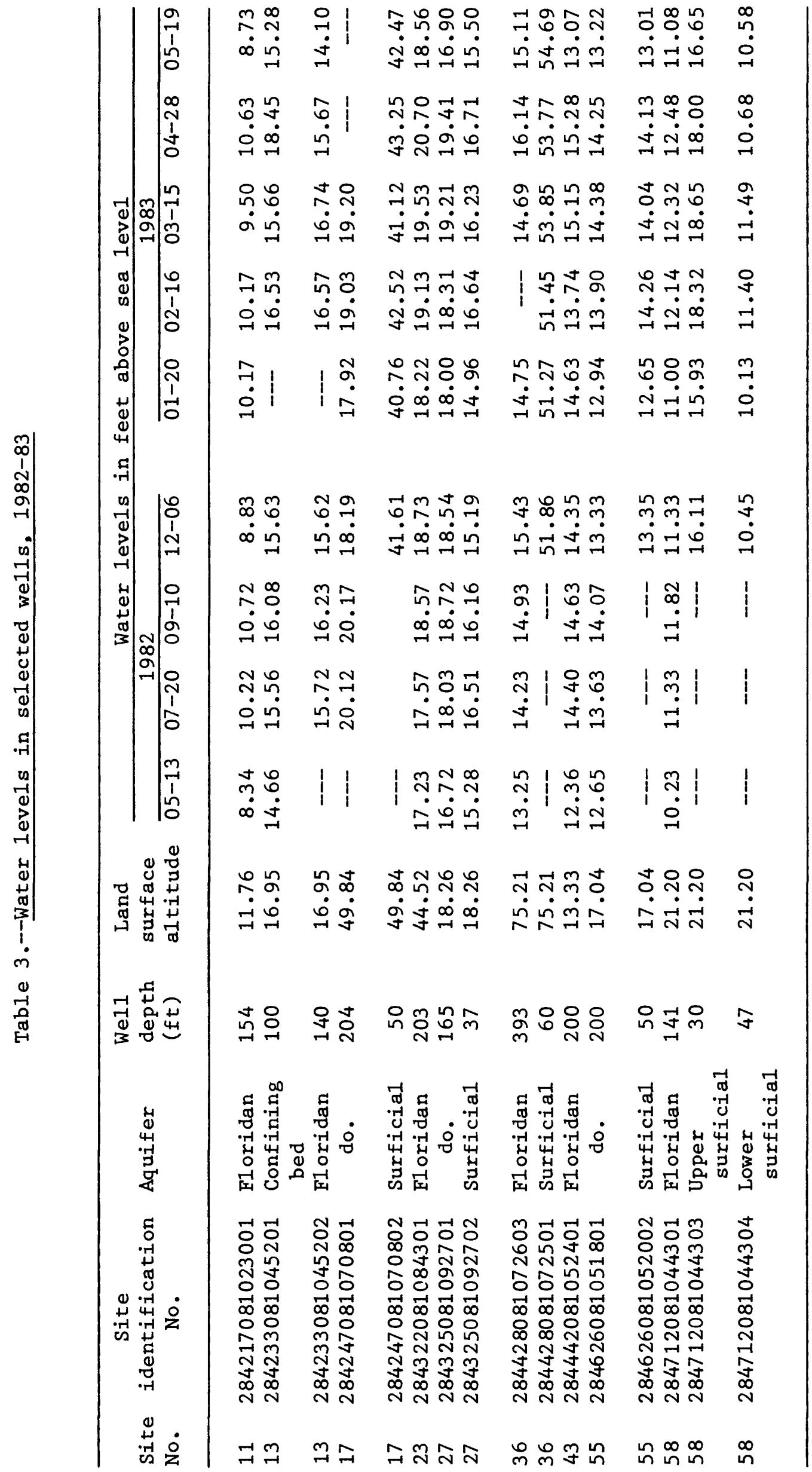




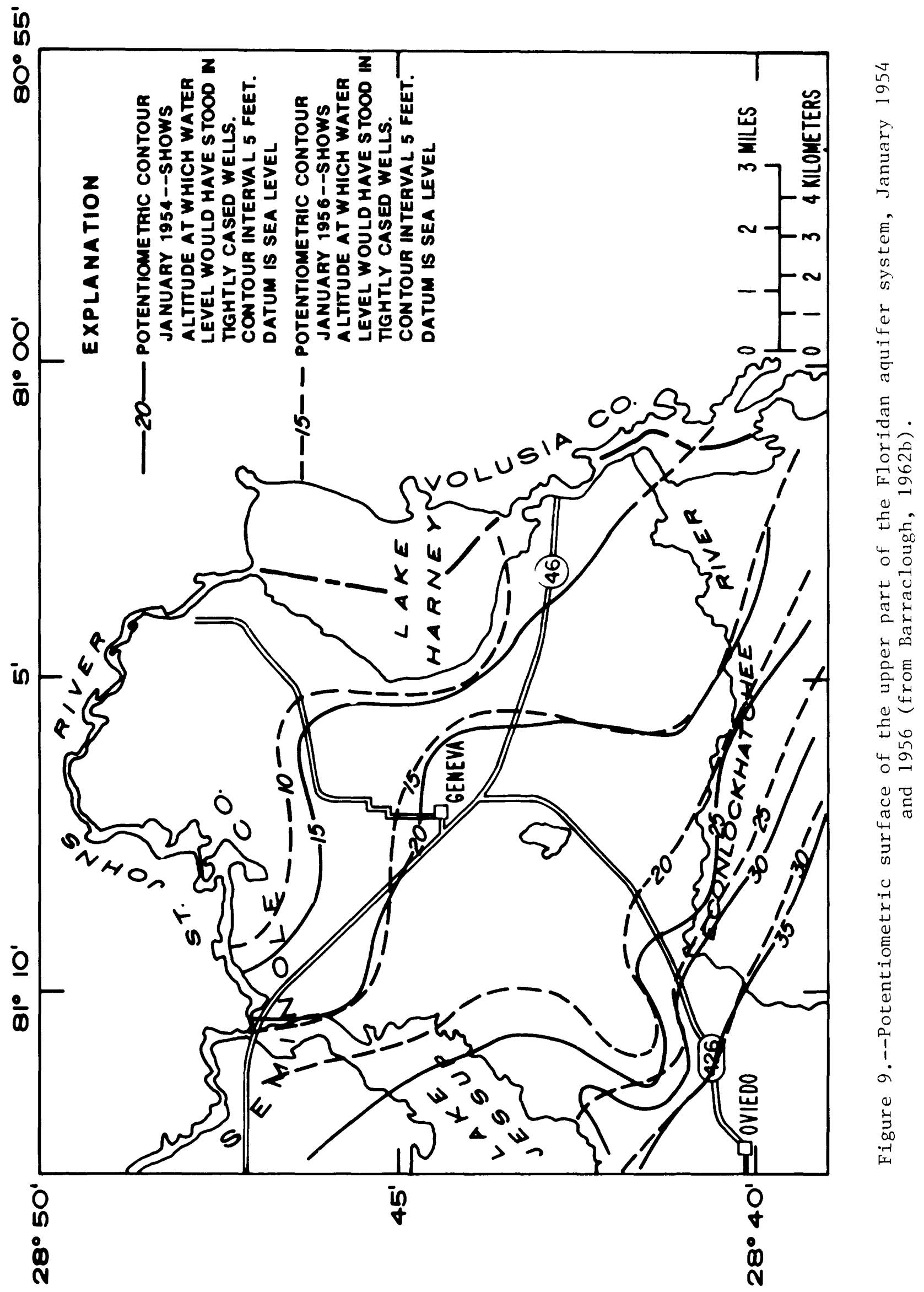




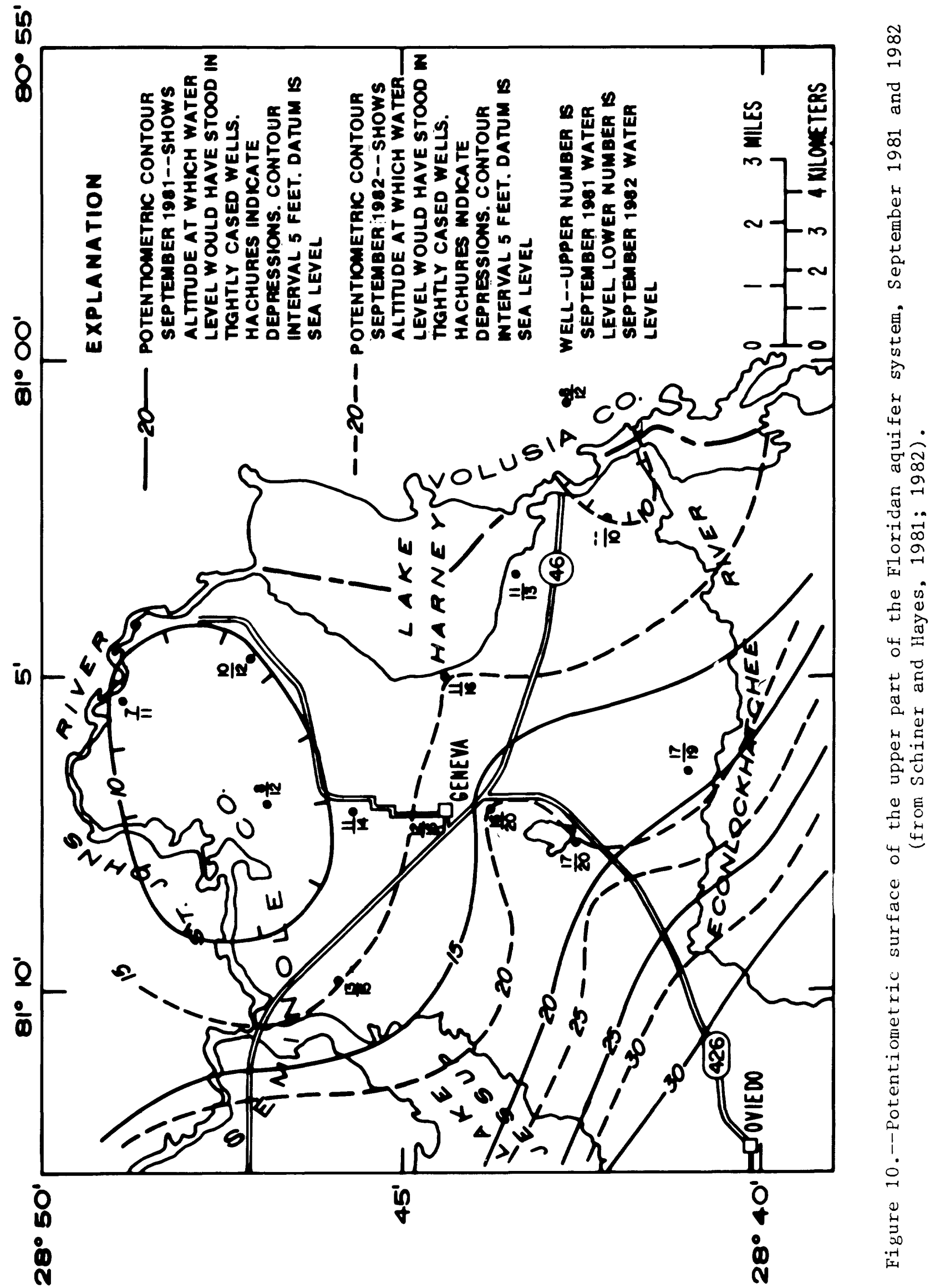




\section{TEST DRILL ING}

\section{Purposes}

Several test wells were drilled to obtain geologic and hydrologic data for this study. Specific data of interest included information on: (1) the thickness and 1ithology of material overlying the Floridan aquifer system, (2) the water-bearing properties of the Floridan aquifer system, and (3) the changes in water quality with location and depth.

\section{Site Selection and Techniques}

Eight 200-foot deep we11s and one 400-foot deep we11 were drilled at 1 ocations shown in figure 11. Sites were selected to obtain the most information as stated above, with the additional considerations of accessibility of the site to the drill rig and permission from the property owners to drill. The 200-foot deep wells were drilled by air rotary and the 400 -foot deep well by cable tool. The drilling techniques were selected to facilitate collection of water-quality samples and to obtain as much geologic information as possible while still allowing more rapid drilling than, for example, continuous splitspoon sampling or coring would provide. The 400-foot deep well at site 36 was drilled in conjunction with the Floridan Aquifer Regional Aquifer Systems Analysis study. Also, one auger hole and three shallow wells from which splitspoon samples were collected, were drilled to depths of less than 60 feet. A core of 1imestone from the Floridan aquifer system was obtained at site 23 .

Geologic and geophysical logs for the test holes are shown in figure 12 and geologic sections are shown in figures 13,14, and 15. In the following sections, the strata are discussed in the order penetrated.

\section{Holocene to Miocene Deposits}

Deposits of Holocene to Miocene age range in thickness from less than 50 feet at site 27 to as much as 137 feet at site 13 (fig. 12). The post-Miocene deposits were sampled by auger cuttings and split-spoon cores at sites 17, 27 . 36, 55, and 58. These deposits are predominantly sand and clayey sand. The thickest clay was at site 8, a topographically low area where ground water has high chloride concentrations. The thick deposits of clay there have probably prevented saline water from being flushed out of the aquifer by recharge water.

The upper Miocene deposits are mostly she11, sand, and clayey sand. These deposits range in thickness from about 20 feet at sites 11 and 23 to 70 feet at site 55. Shell beds in the upper Miocene deposits yield as much as $50 \mathrm{gal} / \mathrm{min}$ to 2-inch diameter wells at some sites (for example at sites 7, 24, and 27).

Laboratory hydraulic conductivities of samples of clay from site 58 and sand from site 36 were $1.7 \times 10^{-5} \mathrm{ft} / \mathrm{d}$ for the clay and $9.33 \mathrm{ft} / \mathrm{d}$ for the sand. 


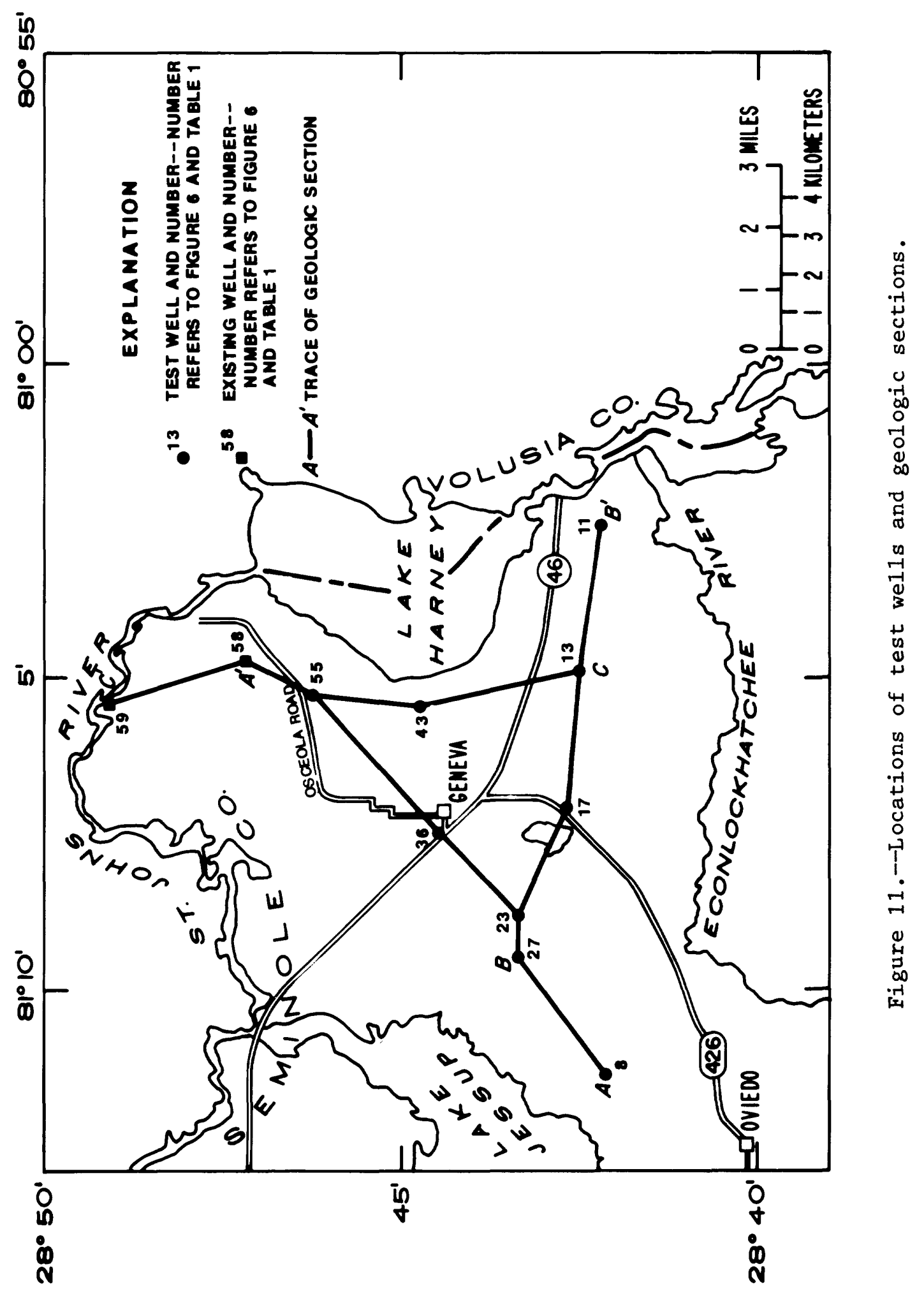


SITE 8 SOISTMAN

Well 284207081111601 Land surface altitude is 8.40 feet

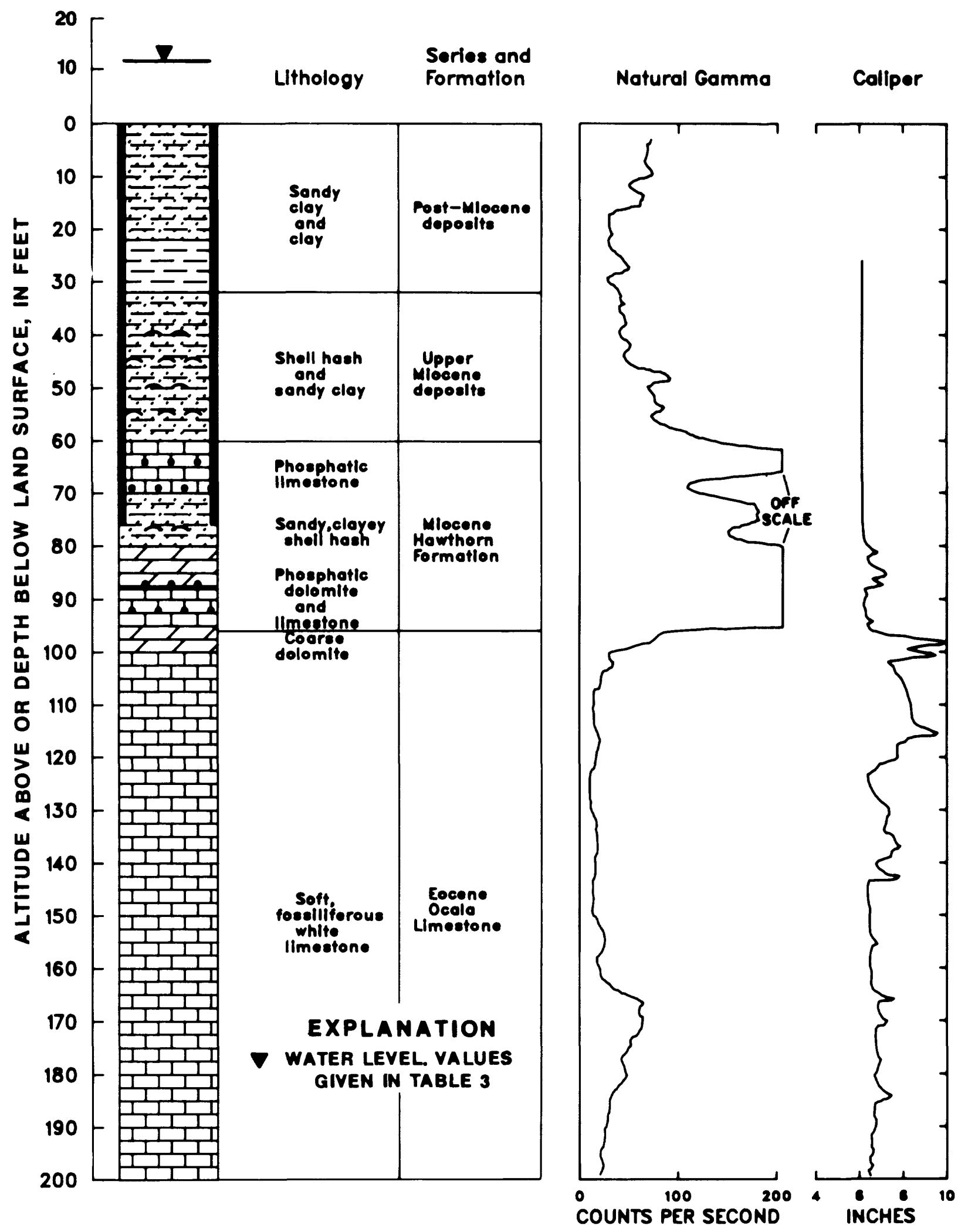

Figure 12.--Geologic and geophysical logs of test we11s. 
SITE 11 KILBEE RANCH \#3

Well $284217081023001 \quad$ Land surface altitude is 11.76 feet

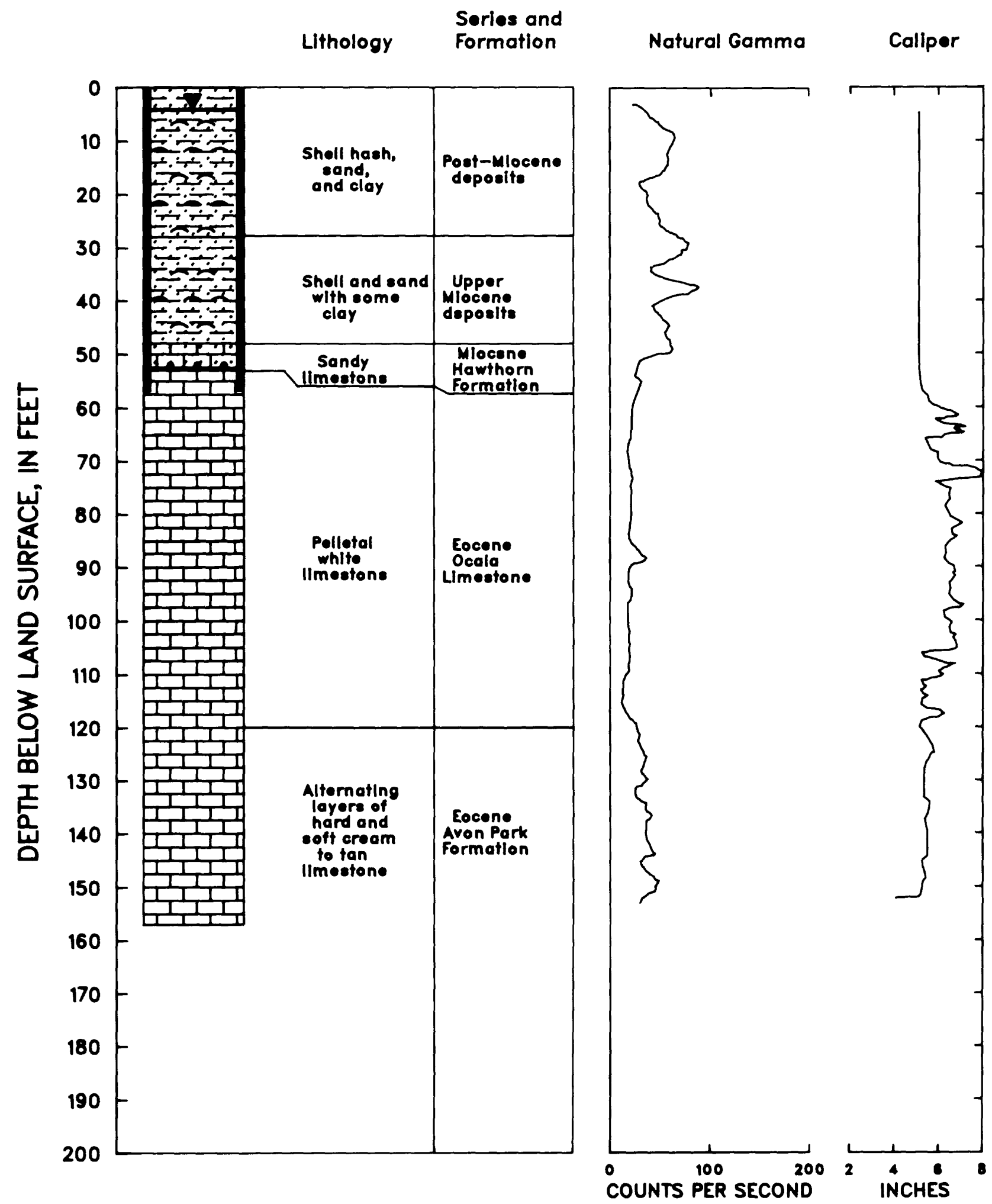

Figure 12.--Geologic and geophysical logs of test wells--Continued. 
SITE 13 KILBEE RANCH \#1 AND \#2 Wells 284233081045201 and 02 Land surface altitude is 16.95 feet

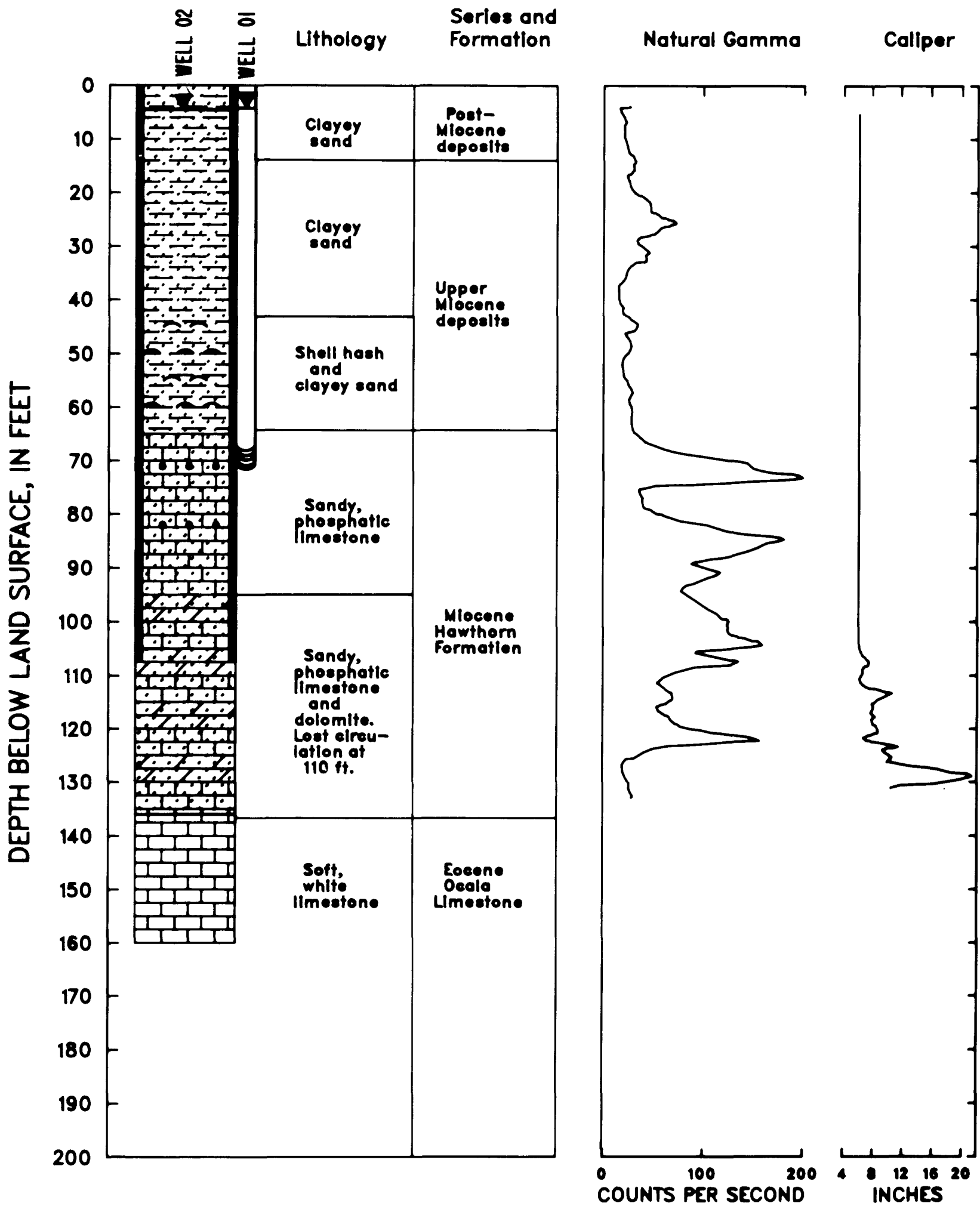

Figure 12.--Geologic and geophysical logs of test wells--Continued. 
SITE 17 OLD MIMS ROAD

Wells 284247081070801 and 02 Land surface altitude is 49.84 feet

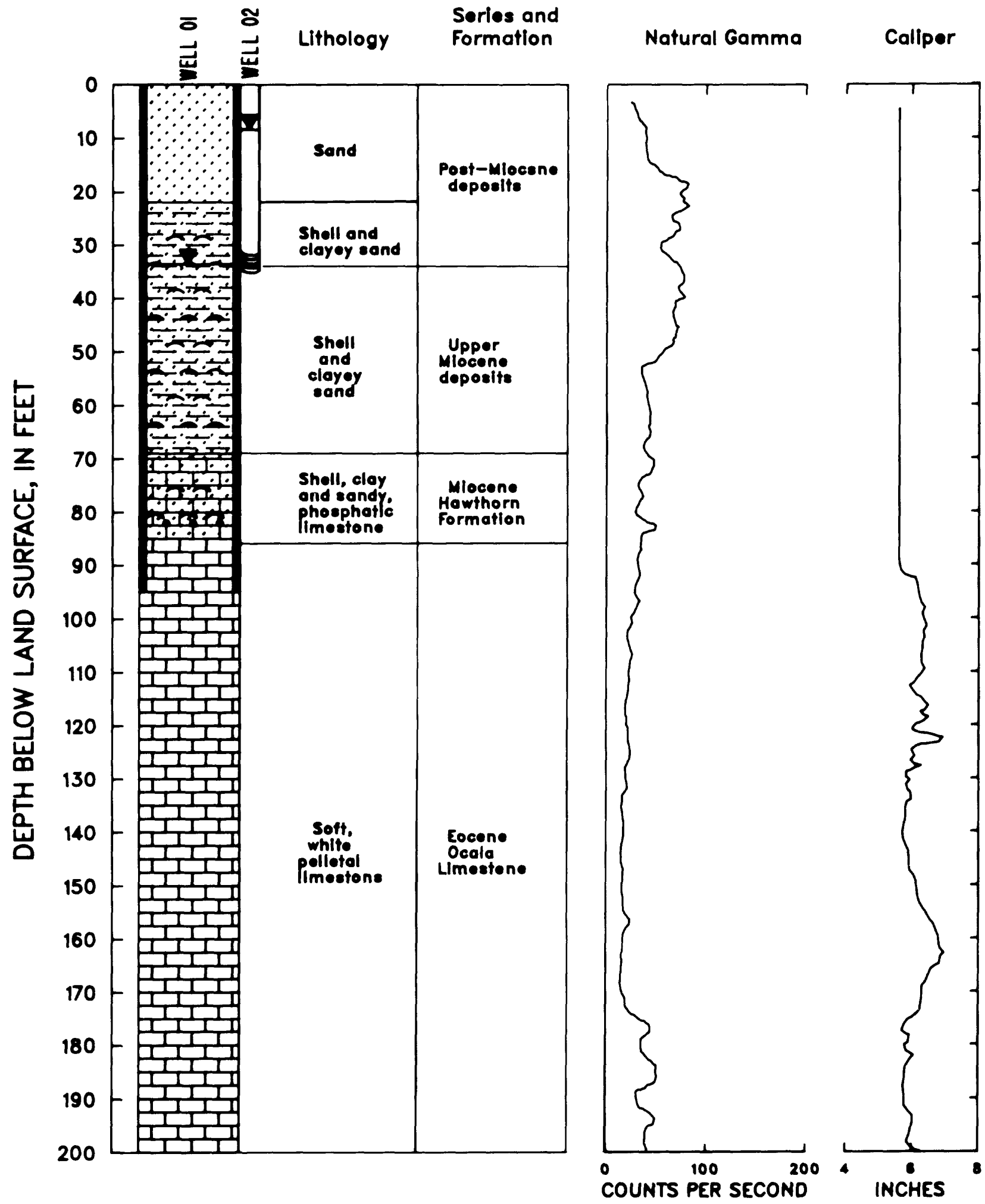

Figure 12.--Geologic and geophysical logs of test we11s--Continued. 


\section{SITE 23 COCKRAN FOREST EAST}

Well 284322081084301

Land surface altitude is $\mathbf{4 4 . 5 0}$ feet

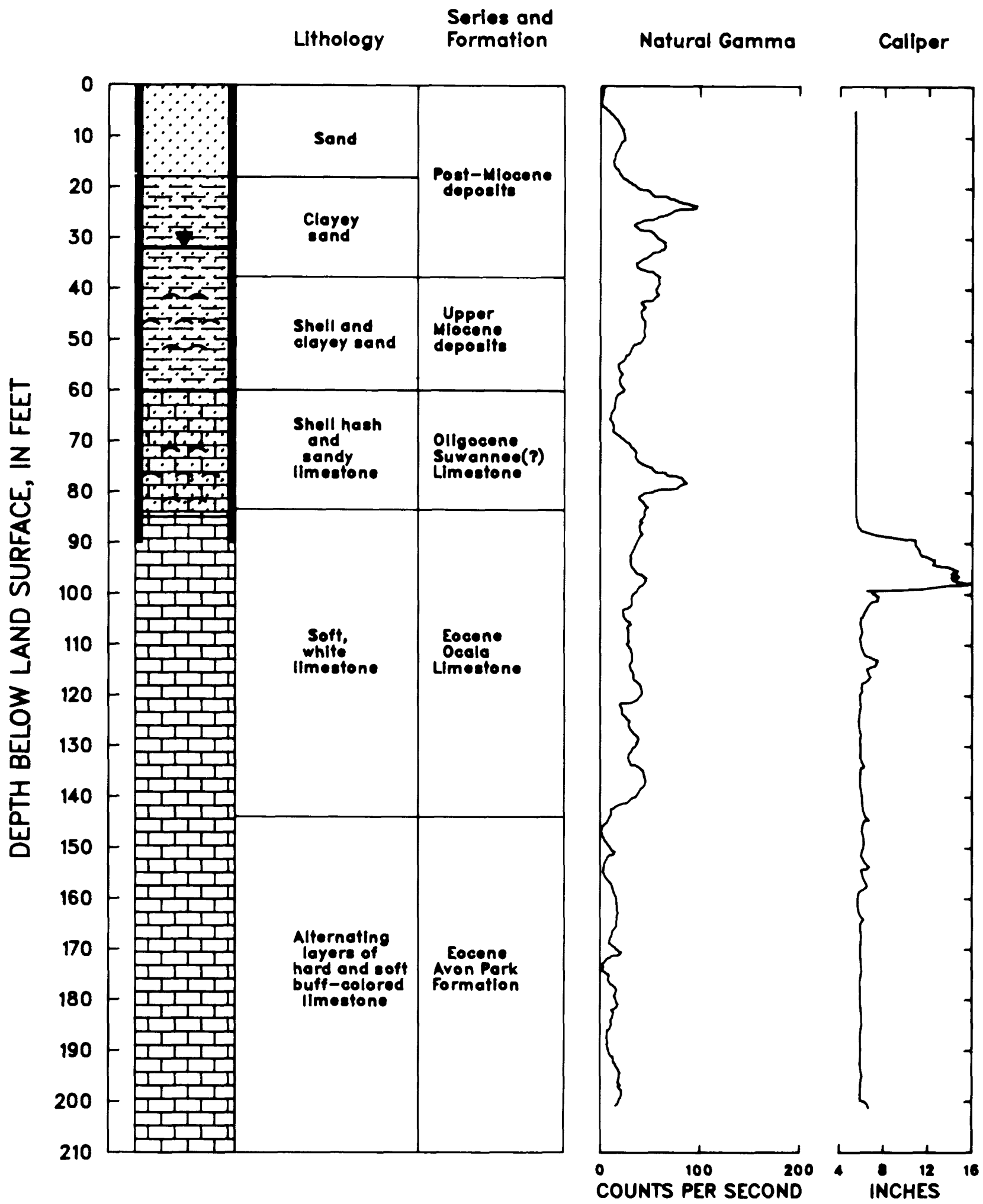

Figure 12.--Geologic and geophysical logs of test wells--Continued. 


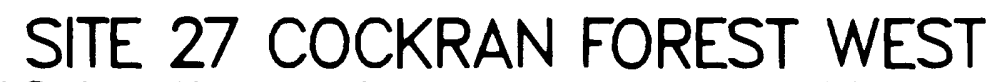

Wells 284325081092701 and 02 Land surface altitude is 18.26 feet

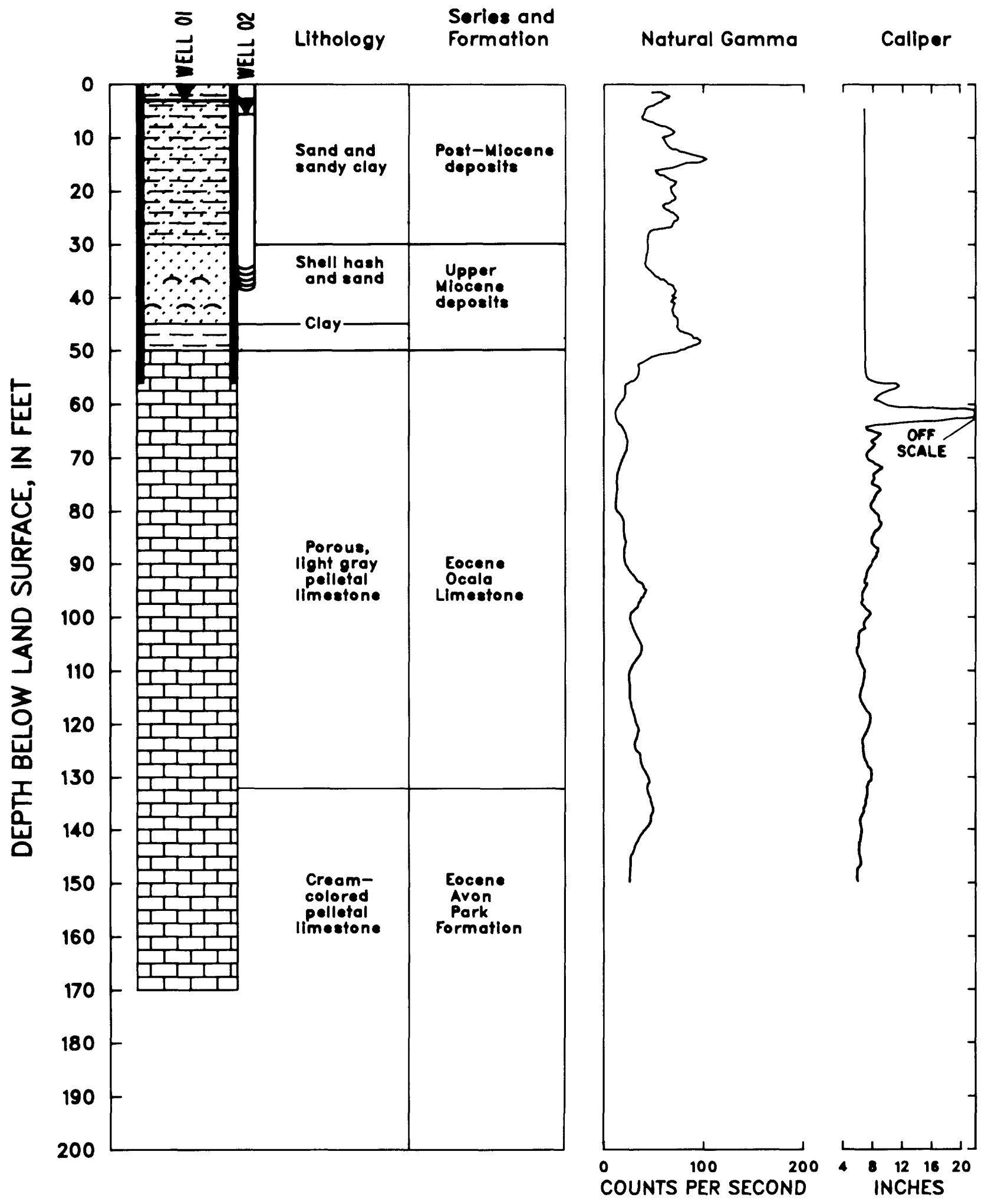

Figure 12.--Geologic and geophysical logs of test wells--Continued. 
SITE 36 AVENUE C

Wells 284428081072603 and Land surface altitude is 75.21 feet $284428081072501 \quad$ Series and

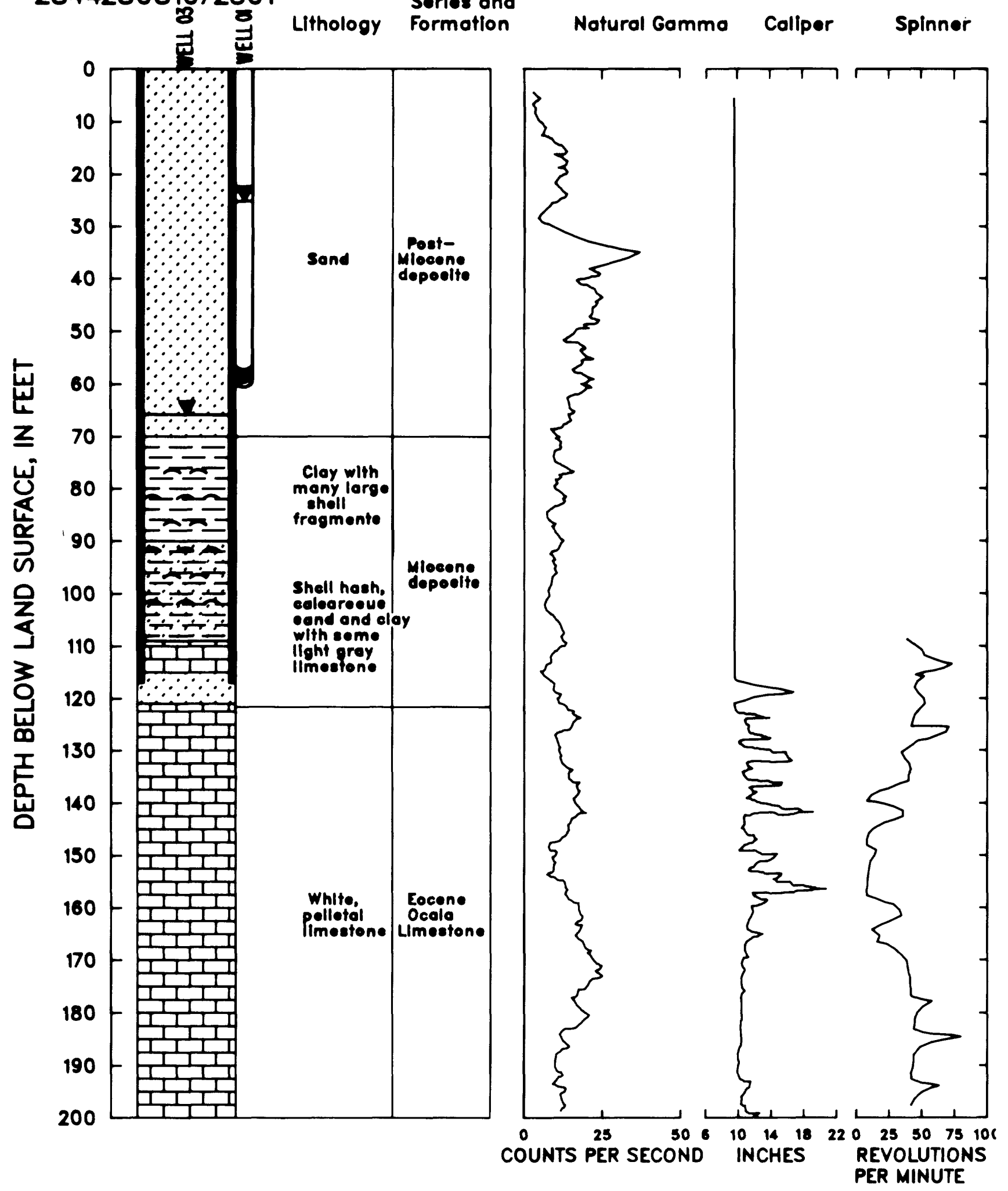

Figure 12.--Geologic and geophysical logs of test wells--Continued. 


\section{AVENUE C (continued) \\ Well 284428081072603 \\ Land surface altitude is 75.21 feet}

\section{Sories and \\ Lithology Formation}

Natural Gamma Caliper

Spinner

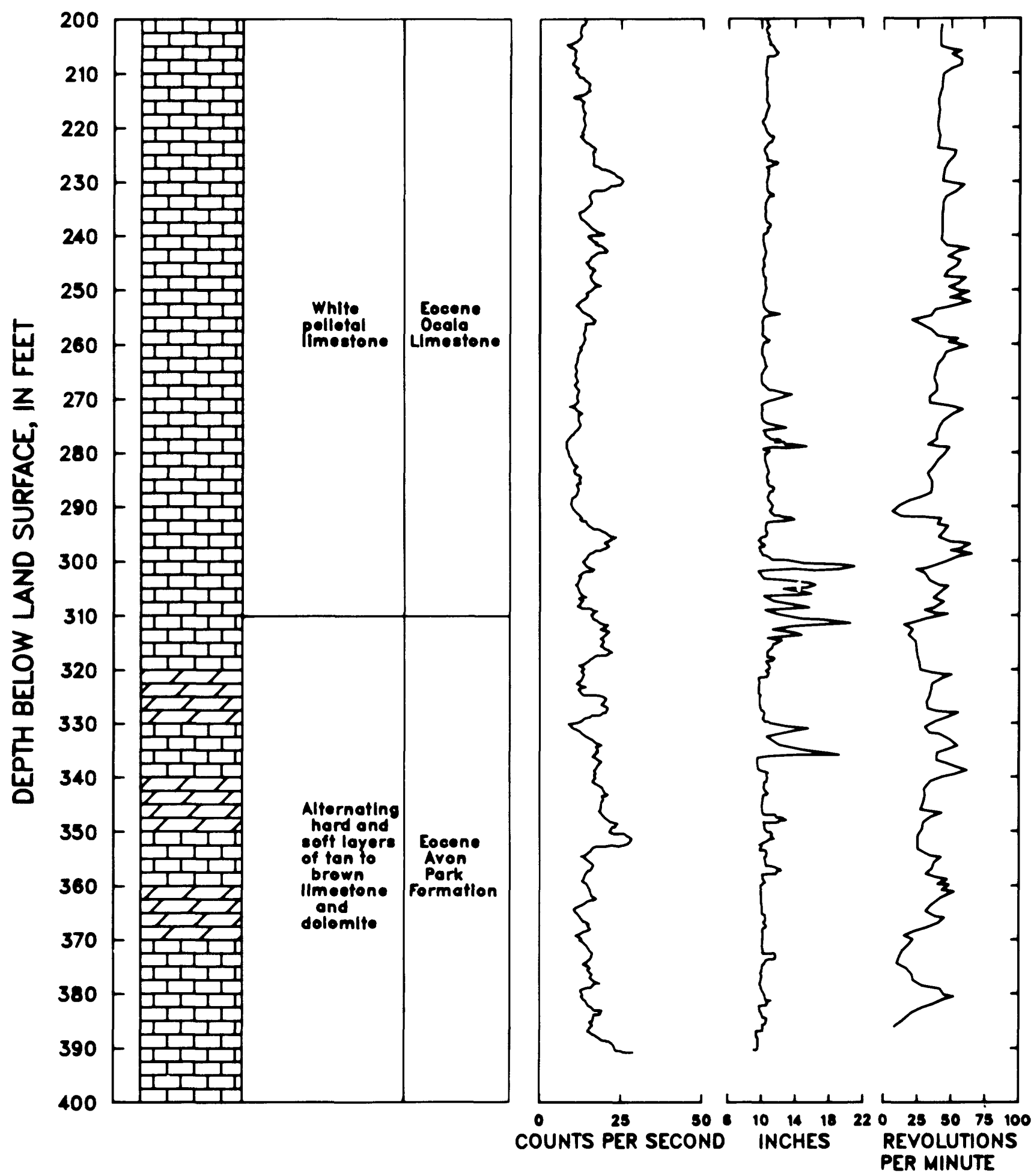

Figure 12.--Geologic and geophysical logs of test we11s--Continued. 
SITE 43 WINONA DRIVE

Well 284442081052401 Land surface altitude is 13.33 feet

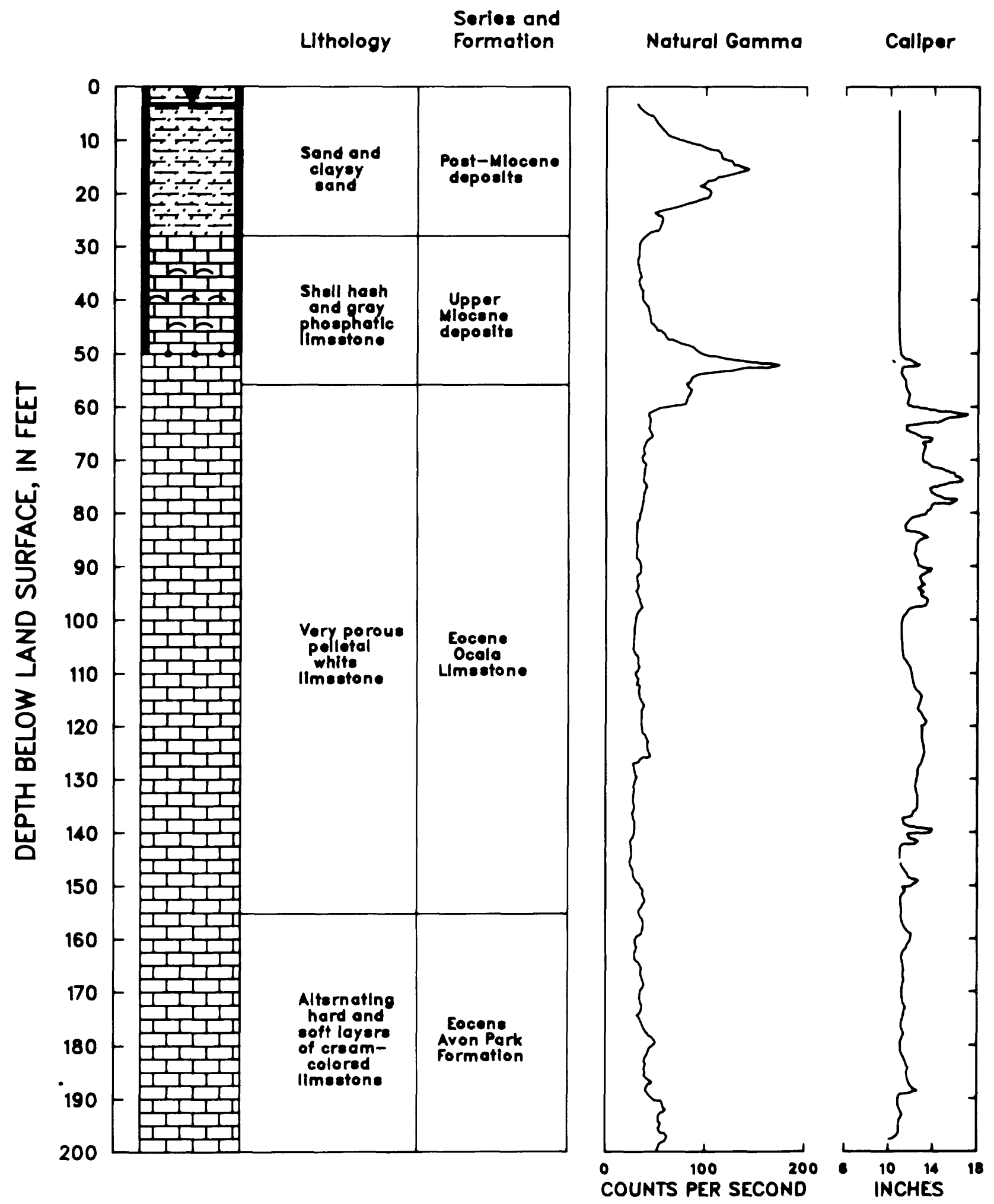

Figure 12.--Geologic and geophysical logs of test wells--Continued. 
SITE 55 KAY ROAD

Wells 284626081051801 and 02 Land surface altitude is 17.04 feet

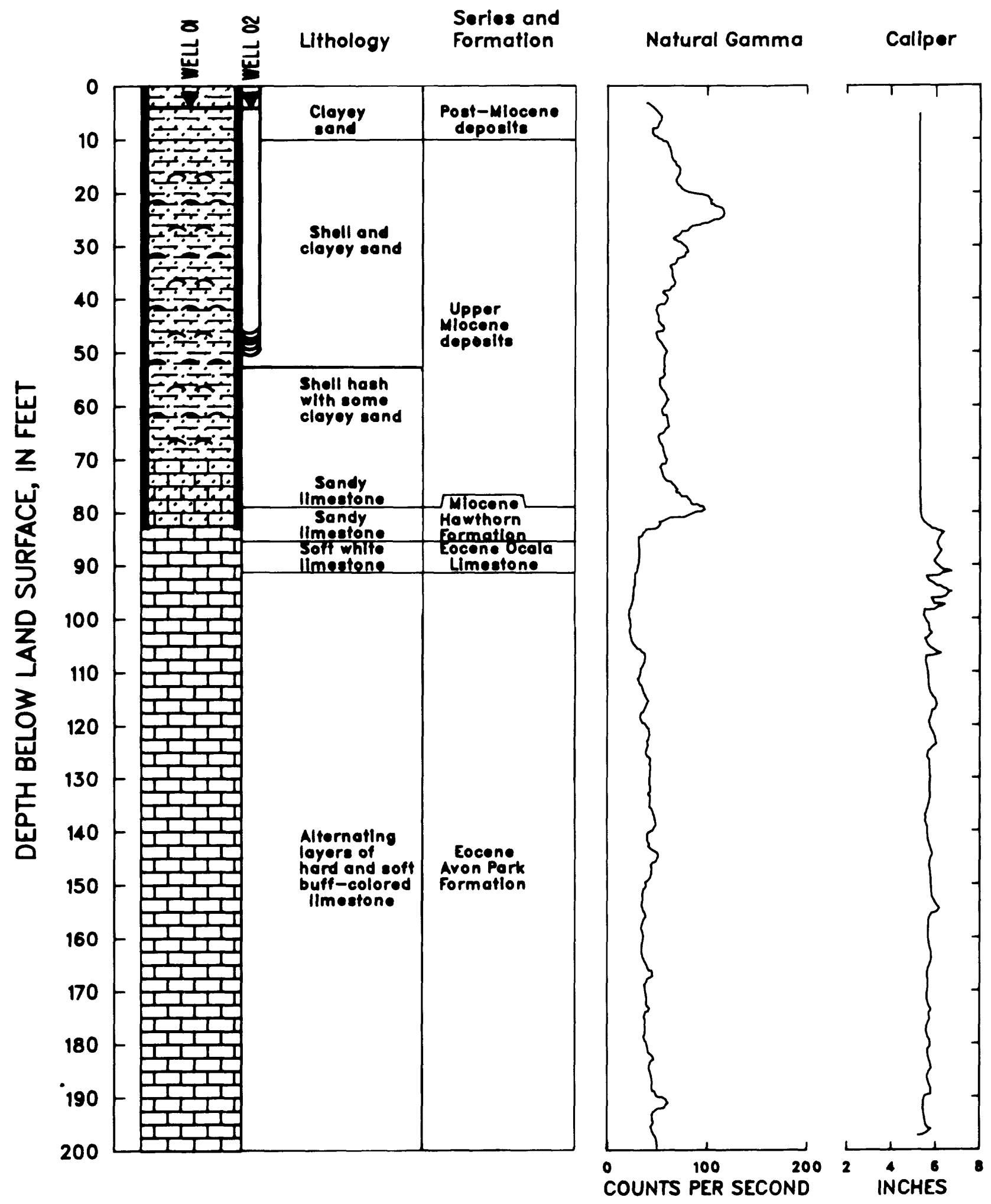

Figure 12.--Geologic and geophysical logs of test wells--Continued. 


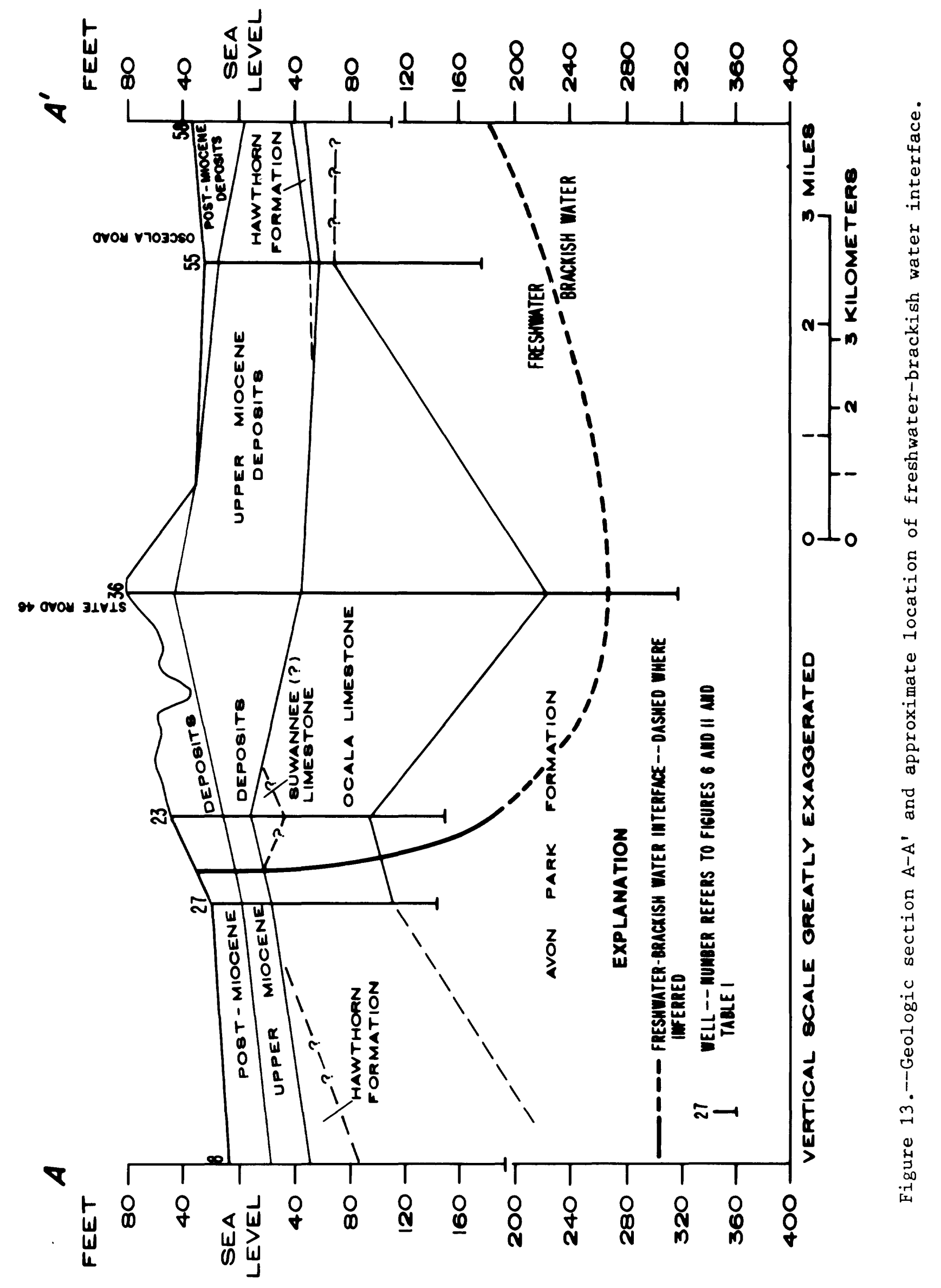




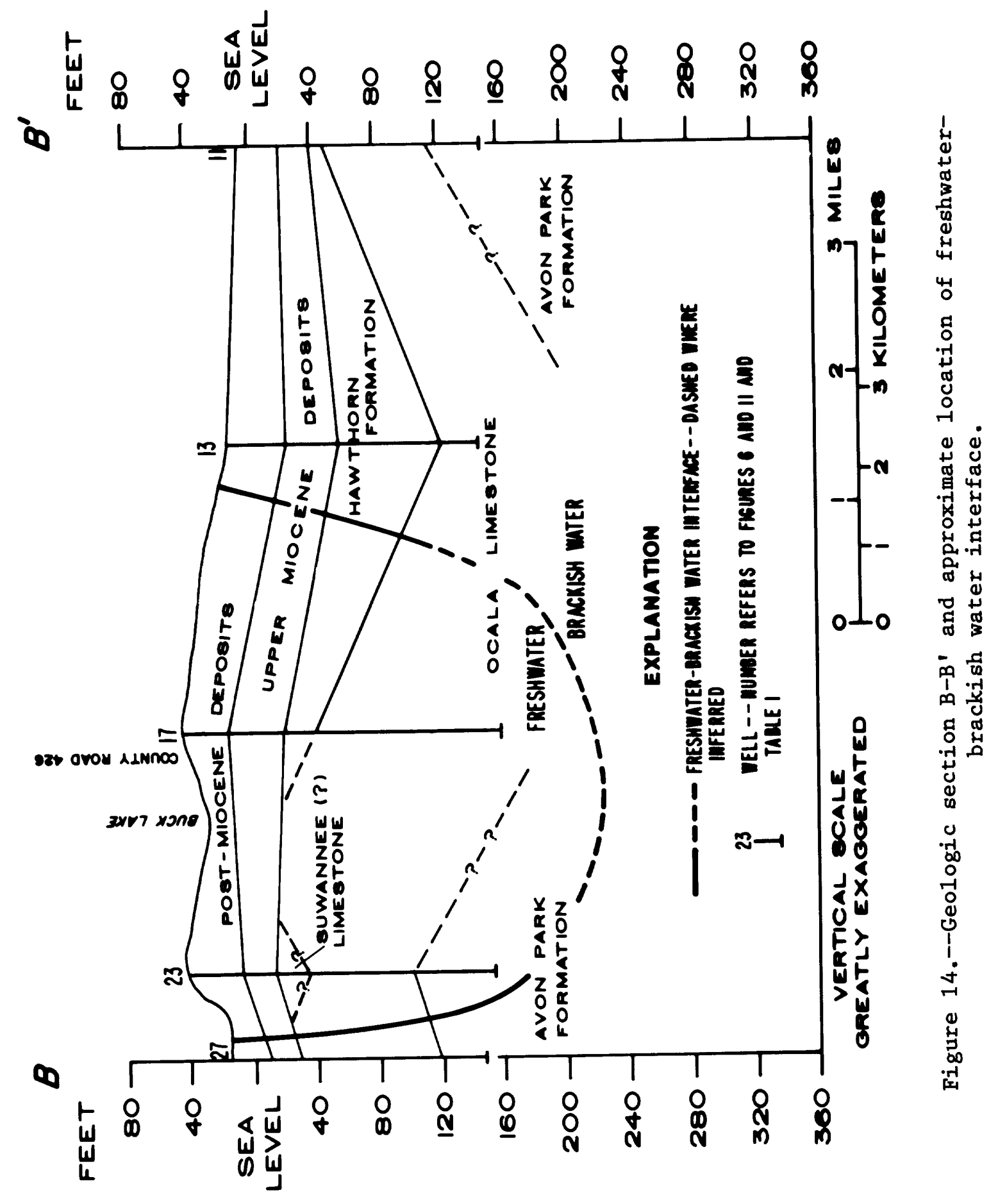




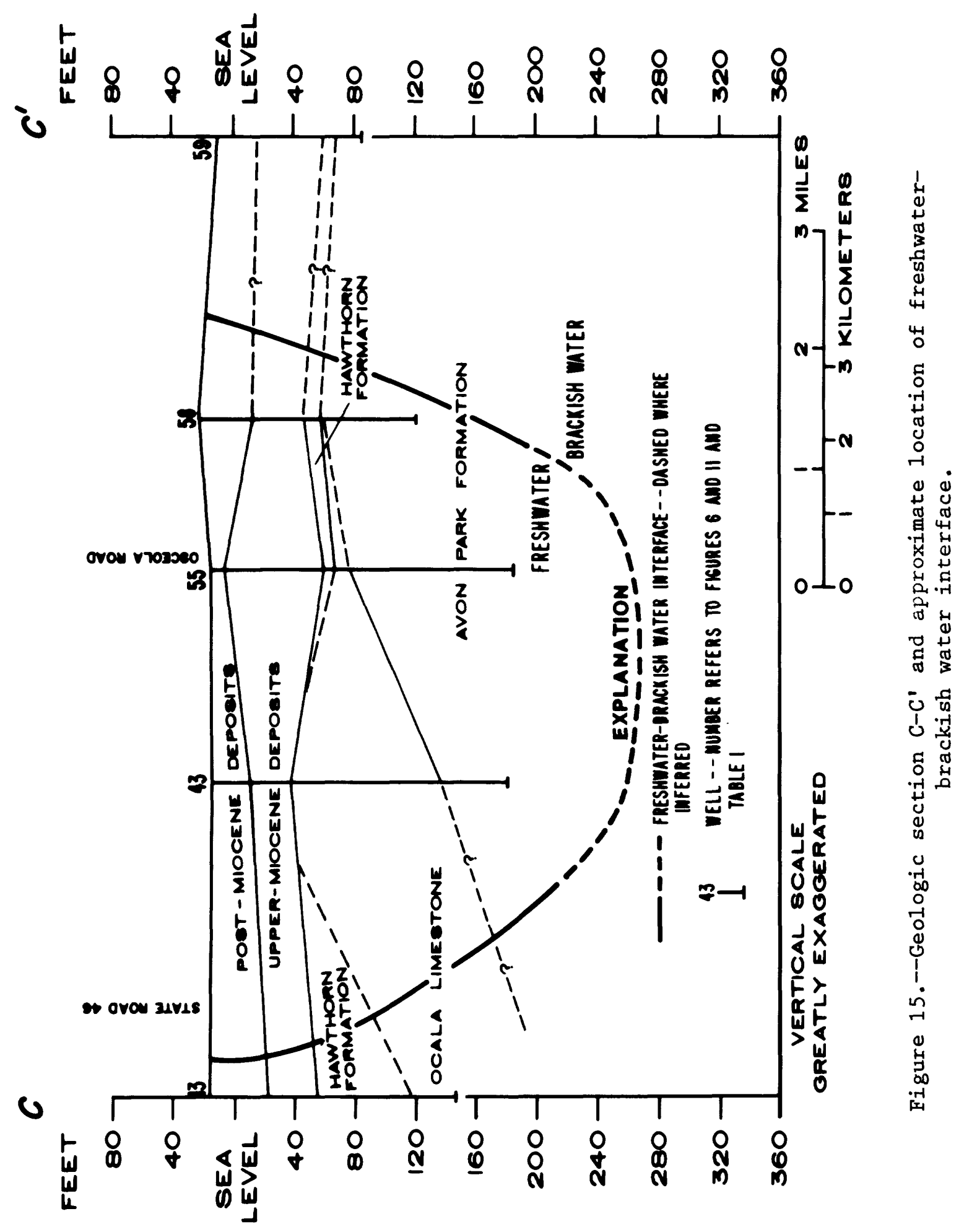


The upper Miocene deposits in part of the study area are underlain by the middle Miocene Hawthorn Formation. The Hawthorn is thin to absent in part of the study area (sites $11,23,27,43,55$ ) but is more than 70 feet thick at site 13 (figs. 12, 13,14,15). It contains no thick clay sequences but is mostly clayey sand and sandy phosphatic limestone and dolomite. The clayey sand of the Hawthorn, along with clay deposits of the upper Miocene, act as a confining layer for the underlying Floridan aquifer system. The Hawthorn limestone and dolomite are hydraulically connected with the Floridan.

\section{O1igocene and Eocene Limestones}

Description.--Underlying the Miocene deposits are soft, permeable 1imestones of Oligocene and Eocene age which comprise the Floridan aquifer system. Throughout most of the area, the Eocene Ocala Limestone is the uppermost 1imestone of the Floridan although at site 23 the 01 igocene Suwannee Limestone is tentatively identified. The top of the aquifer ranges from about 20 feet below sea leve1 (58 feet below land surface) at site 23 to 120 feet below sea level (137 feet below land surface) at site 13. The limestone surface is very weathered, eroded, and pockmarked with depressions as evidenced by the presence of cavities, the weathered limestone drill cuttings recovered, and the areal variation in altitude of the top of the Floridan. Cavity fill material recovered during drilling contained many well-rounded fragments of hard, gray, Hawthorn limestone. The Suwannee and Ocala Limestones are soft, white- to- light gray, fossiliferous, and very porous. The thickness of the Ocala Limestone ranges from about 200 feet at site 36 to about 5 feet at site 55 where the Ocala is almost entirely eroded (figs. 12, 13, 14, and 15).

Underlying the Ocala is the Avon Park Formation that consists of alternating layers of hard and soft light tan to brown limestone, dolomite, and dolomitic limestone. The bottom of the Avon Park was not penetrated during test drilling.

Water-bearing properties.--Well yield generally increases with depth of penetration into the limestones of the Floridan. The 400-foot deep test hole at site 36 was tested during drilling with a 2 horsepower submersible pump at several depths. The yield and specific capacity of the well were as follows:

\begin{tabular}{llcc}
$\begin{array}{c}\text { Wel1 depth } \\
(\mathrm{ft})\end{array}$ & \multicolumn{1}{c}{ Formation } & $\begin{array}{c}\text { Yield } \\
\text { (gal/min) }\end{array}$ & $\begin{array}{c}\text { Specific capacity } \\
{[\text { (gal/min)/ft] }}\end{array}$ \\
\hline & & & \\
207 & Upper part of Ocala & 40 & 2.4 \\
294 & Lower part of Ocala & 65 & 4.6 \\
345 & Upper part of Avon Park & 75 & 12.7 \\
400 & Avon Park & 116 & 12 (estimated)
\end{tabular}

The entire open section of the hole (116-400 feet) was also pumped with a 4 horsepower submersible pump for about 2 hours at $280 \mathrm{gal} / \mathrm{min}$. Drawdown during pumping could not be measured, but the water level recovered to static level within 20 minutes. 
Comparison of the caliper $10 \mathrm{~g}$ and a flow meter traverse of the well at site 36 ( $\mathrm{fig}$. 12) indicates that much flow is from two cavernous $z$ ones. The most productive zone extends from 296 feet to 322 feet (lower part of Ocala Limestone-upper part of Avon Park Formation); significant flow also comes from a zone extending from 120 feet to 140 feet below land surface (upper part of Ocala Limestone).

At site 55 (where the Ocala Limestone is very thin) well yield was lower than from the other 200-foot deep test wells. During drilling with air, the discharge of the well surged, indicating that the yield was not sufficient to keep up with the rate at which water was forced out of the well by the air compressor. Site 55 was the only site at which this phenomenon occurred.

Transmissivity values at three sites in the Geneva area calculated by Tibbals (1977, fig. 14) using the recovery method are as follows:

$$
\begin{array}{lrrll}
\text { Site } 51 & 17,000 \mathrm{ft} 2 / \mathrm{d} & \text { (aquifer penetration about } 50 \mathrm{feet} \text { ) } \\
\text { Site } 56 & 1,700 \mathrm{ft} 2 / \mathrm{d} & \text { (aquifer penetration about } 80 \mathrm{feet} \text { ) } \\
\text { Site } 58 & 3,700 \mathrm{ft} 2 / \mathrm{d} & \text { (aquifer penetration about } 70 \mathrm{feet} \text { ) }
\end{array}
$$

Using a method described by Brown (1963, p. 336-338) transmissivity, based on the specific capacity, at site 36 is about $4,100 \mathrm{ft}^{2} / \mathrm{d}$.

The values described above represent the lower limits for transmissivity of the upper part of the Floridan aquifer system in the Geneva area because none of the wells penetrate the full thickness of the upper part of the aquifer system. Transmissivity values based on individual aquifer tests are valuable as indicators of the potential yield at particular wells, but because of the heterogeneous and anisotropic nature of the cavernous limestone aquifer system, Tibbals (1981, p. 12-13) believes that transmissivity values derived from ground-water flow model calibrations have more regional significance than individual test values. Thus, the transmissivity values from Tibbals' model (1981, fig. 6), which range from 35,000 to $100,000 \mathrm{ft}^{2} / \mathrm{d}$ are used for hydrologic analyses in this report. 


\section{CHEMICAL QUAL ITY OF DATER}

Water samples were analyzed to describe the general water quality of the area and to define more precisely the lateral and vertical extent of the freshwater lens. Geochemical analysis of the data can also help in understanding the hydrologic system in Geneva and, in particular, the recharge process. It can help, for example, to determine the source of the saline water, and if active intrusion or flushing is occurring.

Initially, 37 wells were sampled for chloride and hardness in May-June 1981. Subsequent sampling concentrated on wells in the transitional zone between freshwater and brackish water. Forty-nine wells were sampled for major constituents and iron in January-February 1982 and again in October 1982. Samples from test wells were taken during drilling at the top of the Floridan aquifer system and composite samples collected from the total cpen hole to determine if water quality changed with depth. At site 36 (the 400-foot deep wel1) composite water samples were collected at about 50-foot intervals and thief samples were collected from the bottom of the hole. Specific conductance was monitored continuous1y during the drilling of test wells.

Depending on the depth to water, either a centrifugal or submersible pump was used to sample existing wel1s. The 200-foot deep test wells were sampled using compressed air during drilling. Subsequent samples were collected with either a centrifugal or submersible pump. Table 4, which shows water-quality analyses, includes both historic data and data collected during this study. Wells tapping the surficial aquifer are denoted with an $S$ and those tapping the Floridan aquifer system with an $F$.

Chloride is the constituent of most interest in the Geneva area. Samples collected in January-February 1982 show chloride concentrations for a drier-thanaverage dry season (fig. 16). Samples for October 1982 show ch1oride concentrations for the end of the wet season (fig. 17). Comparison of figures 16 and 17 to figures 4 (composite for 1951-54) and 5 (1973-74, a relatively dry period) indicates that apparently there are no significant changes in chloride concentrations from 1951 to 1982, though the freshwater lens is now better defined because of the existence of more wells to sample.

Some discrepancies were noted between the 1955 data reported by Barraclough (1962b, fig. 36), and the data collected by Tibbals (1977, fig. 11) and data from this study. At site 38, chloride concentration reported in 1955 was $695 \mathrm{mg} / \mathrm{L}$. In 1973, the concentration was $330 \mathrm{mg} / \mathrm{L}$, and in 1982, it was $290 \mathrm{mg} / \mathrm{L}$. The difference between values for 1973 and 1982 is within the error of determination for the method used. At site 58 the 1955 chloride concentration was reported as $1,115 \mathrm{mg} / \mathrm{L}$. In 1973, Tibbals (1977, fig. 11) reported a concentration of 150 $\mathrm{mg} / \mathrm{L}$ after pumping for 6 hours at $90 \mathrm{gal} / \mathrm{min}$. Samples collected for this study had chloride concentrations of 110 and $63 \mathrm{mg} / \mathrm{L}$. The latter sample was collected after pumping about 20 minutes with a centrifugal pump, and the sample with a concentration of $110 \mathrm{mg} / \mathrm{L}$ was collected after clearing the well with compressed air for about one-half hour. Differences between the 1973 and the higher 1982 value are insignificant. The differences between the 1955 data and later analyses are probably due to better collection and analysis procedures used in the 1973 and 1982 studies, rather than from a flushing of saltwater from the aquifer, because water from wells along the southern bank of the St. Johns River has apparently not become fresher. 


\begin{tabular}{|c|c|c|c|c|c|c|c|c|c|c|c|c|}
\hline & 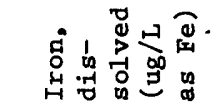 & 율용ㅇ & 융웡요 & 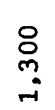 & 육요 & 1 일억 & $\stackrel{\circ}{\vartheta}$ & 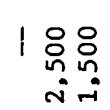 & 유시 & $\underset{1}{8}$ & | 心 品 & 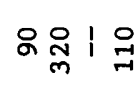 \\
\hline $\begin{array}{l}\text { 四 } \\
\text { प⿺ }\end{array}$ & 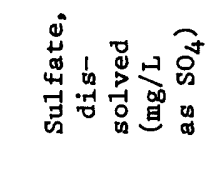 & 육용요 & صุio & స్లి & స్లి స్లి & 윰용 & 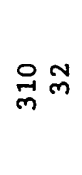 & $1 \pm 0$ & 윰 & 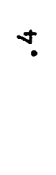 & I $9=$ & 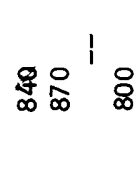 \\
\hline 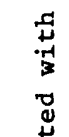 & 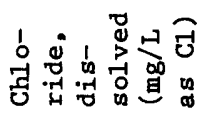 & 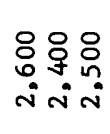 & $\stackrel{\infty}{\rightarrow}$ 유 & $\begin{array}{l}8 \\
\vdots \\
i\end{array}$ & $\begin{array}{l}808 \\
\text { iin }\end{array}$ & 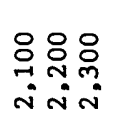 & $\begin{array}{l}80: 0 \\
\text { iñ } \\
\text { in }\end{array}$ & ০̊ & $\begin{array}{l}\text { 8o } 809 \\
\text { in } \\
\text { iñ-i }\end{array}$ & $\underset{-}{*}$ & $\cong \approx$ & 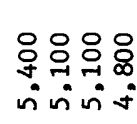 \\
\hline 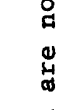 & 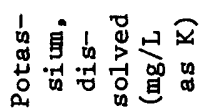 & ㅇำ年 & 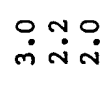 & $\stackrel{\sim}{n}$ & nू n & I읭 & $\vec{\sigma} \stackrel{n}{m}$ & $1 \underset{+}{9}+$ & $\Omega^{1}$ & $\ddot{-1}$ & $\mid \vec{m} \dot{n}$ & $\underset{7}{\stackrel{7}{7} \Omega^{1}}$ \\
\hline 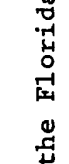 & 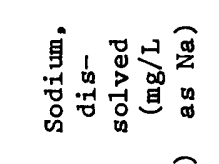 & 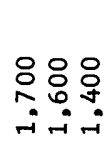 & ఇ ని & $\stackrel{8}{8}$ & : & $\begin{array}{l}1 \\
\text { 'o. } \\
\text { m. } \\
\text {-i }\end{array}$ & 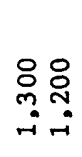 & | & 윰옷 & $\dddot{\sim}$ & $1 m_{\infty}^{n}: 0$ & $\begin{array}{ll} & \\
8 & \circ \\
\circ & \circ \\
\text { min } & \text { i }\end{array}$ \\
\hline 苗 & 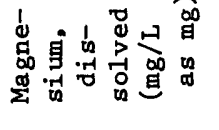 & $\stackrel{\infty}{\wedge}$ 早号 & $\stackrel{M}{\rightarrow} \rightleftharpoons \underset{-1}{*}$ & ঙ্స & 웍웍 & 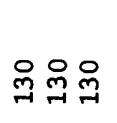 & 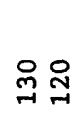 & $\pm=$ & $\infty_{\infty}{ }^{1}$ & $\stackrel{\varphi}{i}$ & $\ddot{\dot{y}} \dot{+} \dot{q}$ & 윰율 \\
\hline 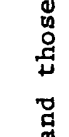 & 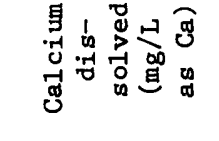 & 矛吕梄 & $\stackrel{n}{\sim} \infty \widetilde{\infty}$ & $\underset{\text { న్ }}{ }$ & 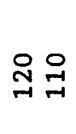 & 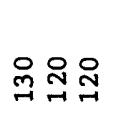 & 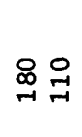 & 1 in & 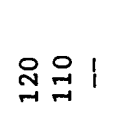 & $N$ & 螨 & 오유 \\
\hline $\begin{array}{l}\infty \\
\text { a } \\
\text { af }\end{array}$ & 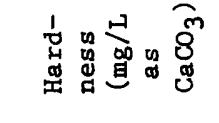 & 옹형 & స్ ํํำ & ๙ั & $\stackrel{n}{n} \underset{N}{n}$ & \&̊ & ڤ̊ㅇㅇ & 吕 & ถูํำ & $\stackrel{\Re}{2}$ & 气ี & 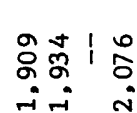 \\
\hline 苞 & 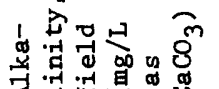 & 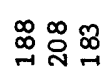 & 충유 & $\stackrel{\infty}{-\infty}$ & 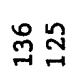 & | & I & $\mid \stackrel{D}{ \pm}$ & 呆昌 1 & 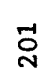 & I્ન & 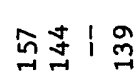 \\
\hline 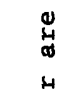 & 赵 & $\stackrel{+}{\sim} \ddot{n}:$ & m: & $\stackrel{r}{r}$ & $\stackrel{m}{i}:$ & I广் & $\because \stackrel{0}{1} 0$ & I뭉. & $\stackrel{\infty}{0}: \stackrel{m}{0}:$ & $\stackrel{\circ}{r}$ & $\mid \stackrel{0}{\circ}$ & 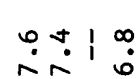 \\
\hline$\stackrel{\Xi}{\vec{\sigma}}$ & 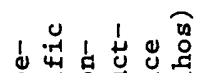 & 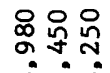 & 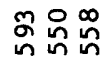 & ㅇ. & 迢员 & 옷윰유. & 융유. & ㅇํㅅ ถูㅇํㅇ & 으유ํำ & 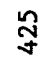 & ్ㅠㄹㄹ & 음윰워 \\
\hline 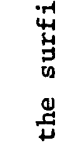 & 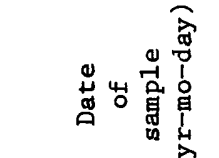 & 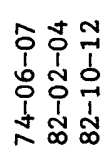 & 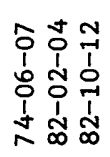 & 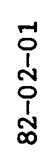 & 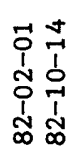 & 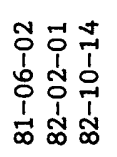 & 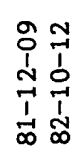 & 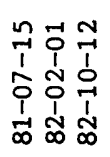 & 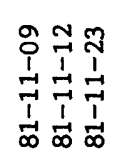 & 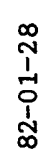 & 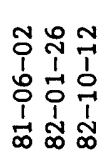 & 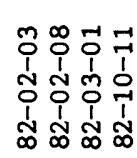 \\
\hline 㤃 & 泉 & w & 四 & 由 & 田 & w & 龱 & $\infty$ & I & 由 & is & |r \\
\hline$\stackrel{n}{7}$ & $\stackrel{\substack{n \\
c}}{\dot{\delta}}$ & $r$ & $N$ & $m$ & + & in & $c$ & n & $\infty$ & $a$ & 움 & $\Rightarrow$ \\
\hline & 点 & 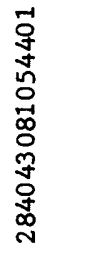 & 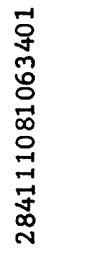 & 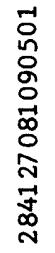 & 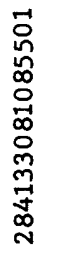 & 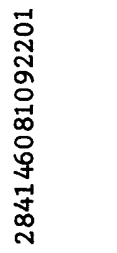 & $\begin{array}{l}-1 \\
0 \\
0 \\
0 \\
0 \\
0 \\
0 \\
0 \\
0 \\
n \\
0 \\
0 \\
0\end{array}$ & 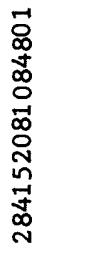 & 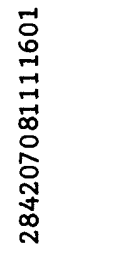 & 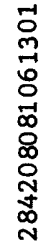 & 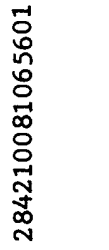 & 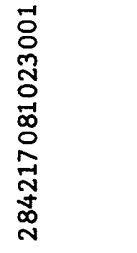 \\
\hline
\end{tabular}




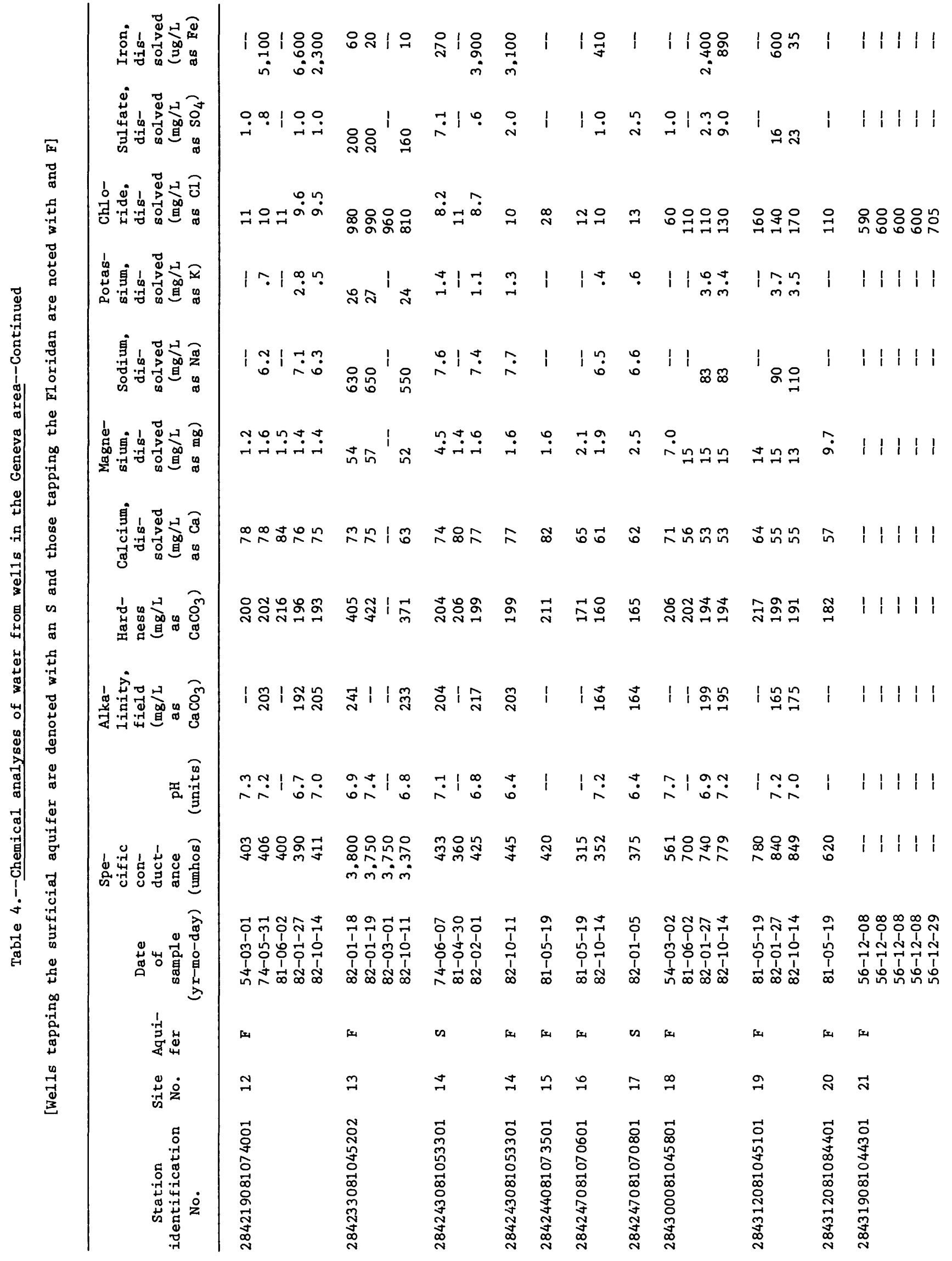




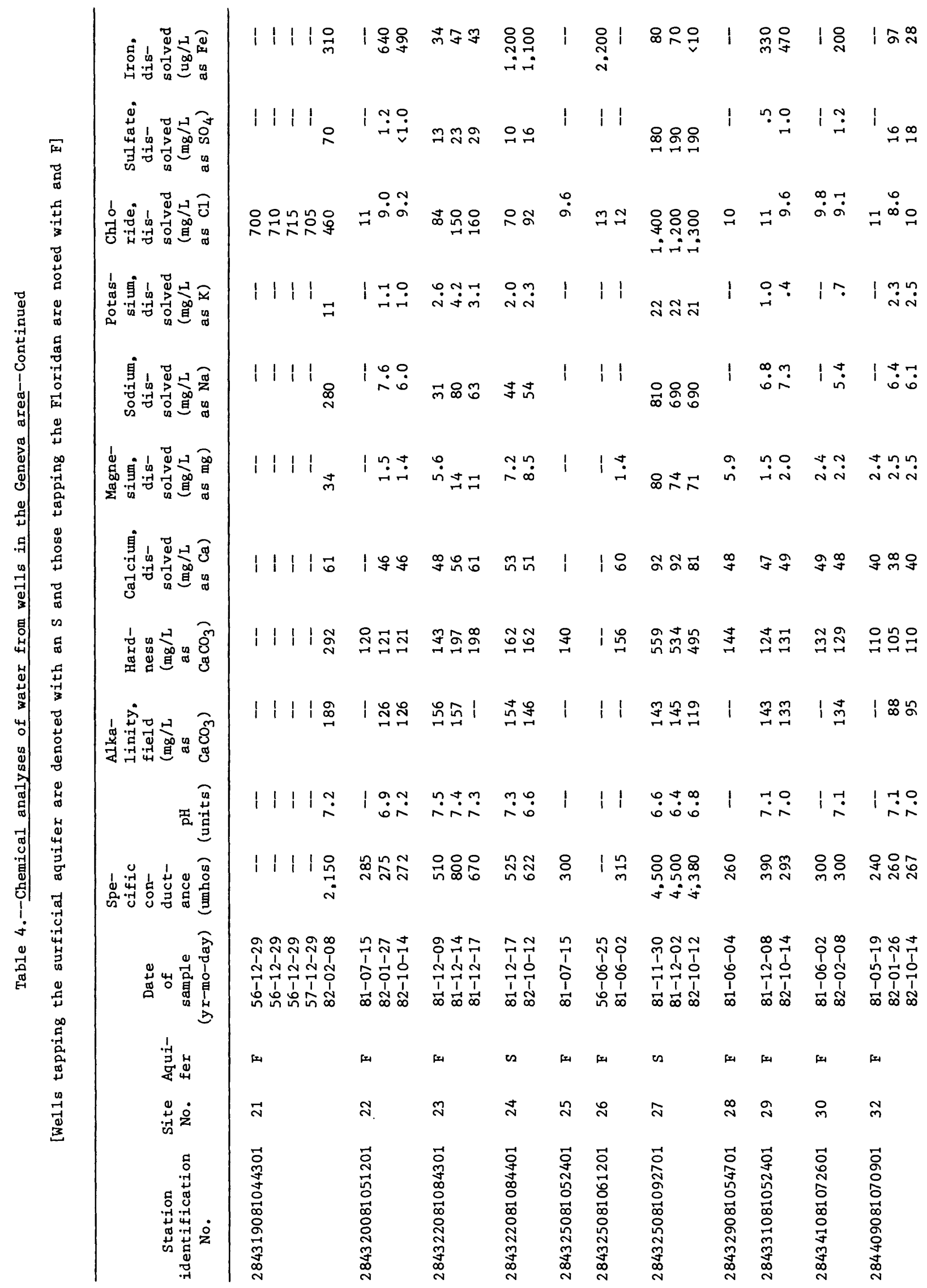




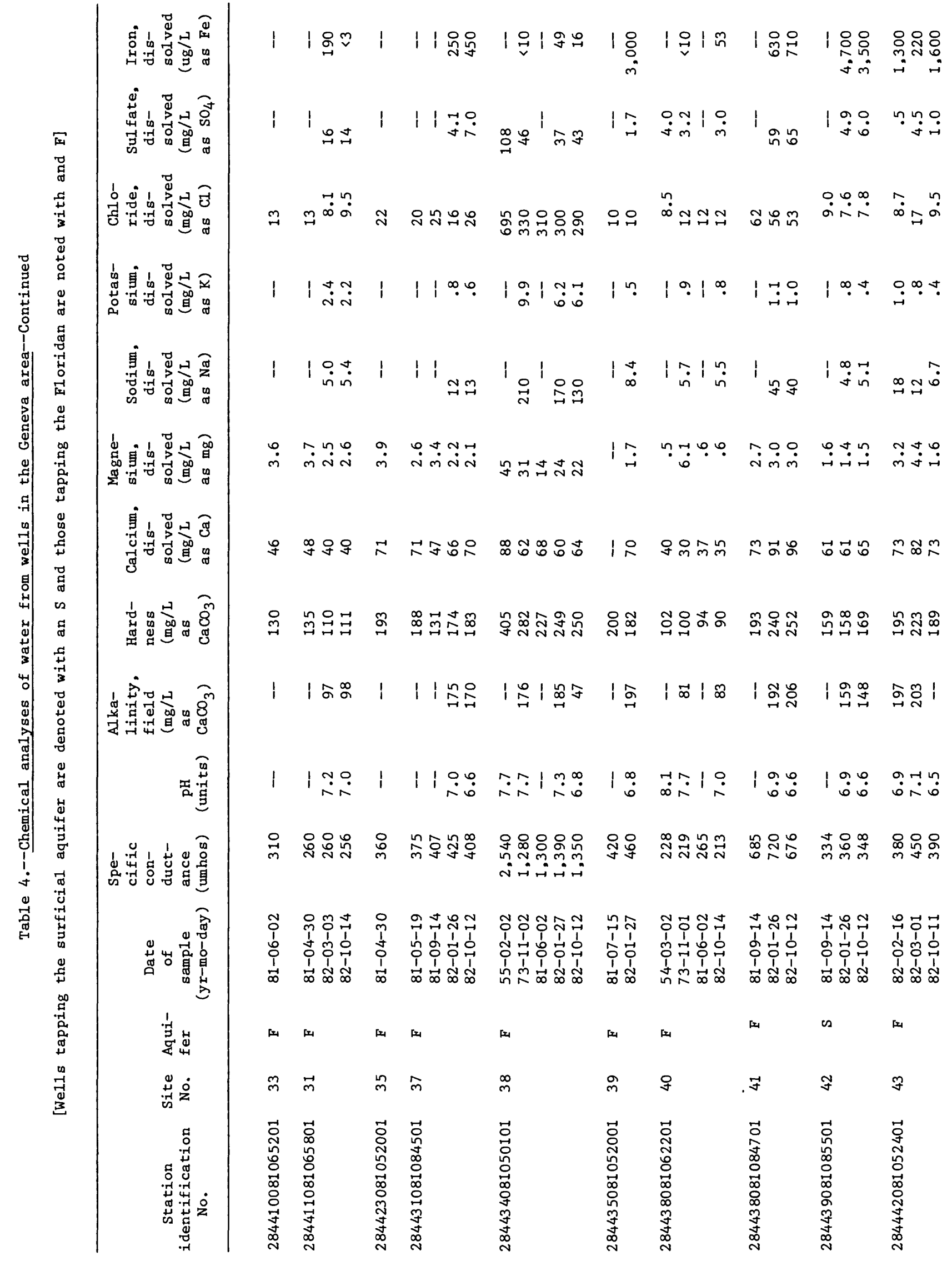




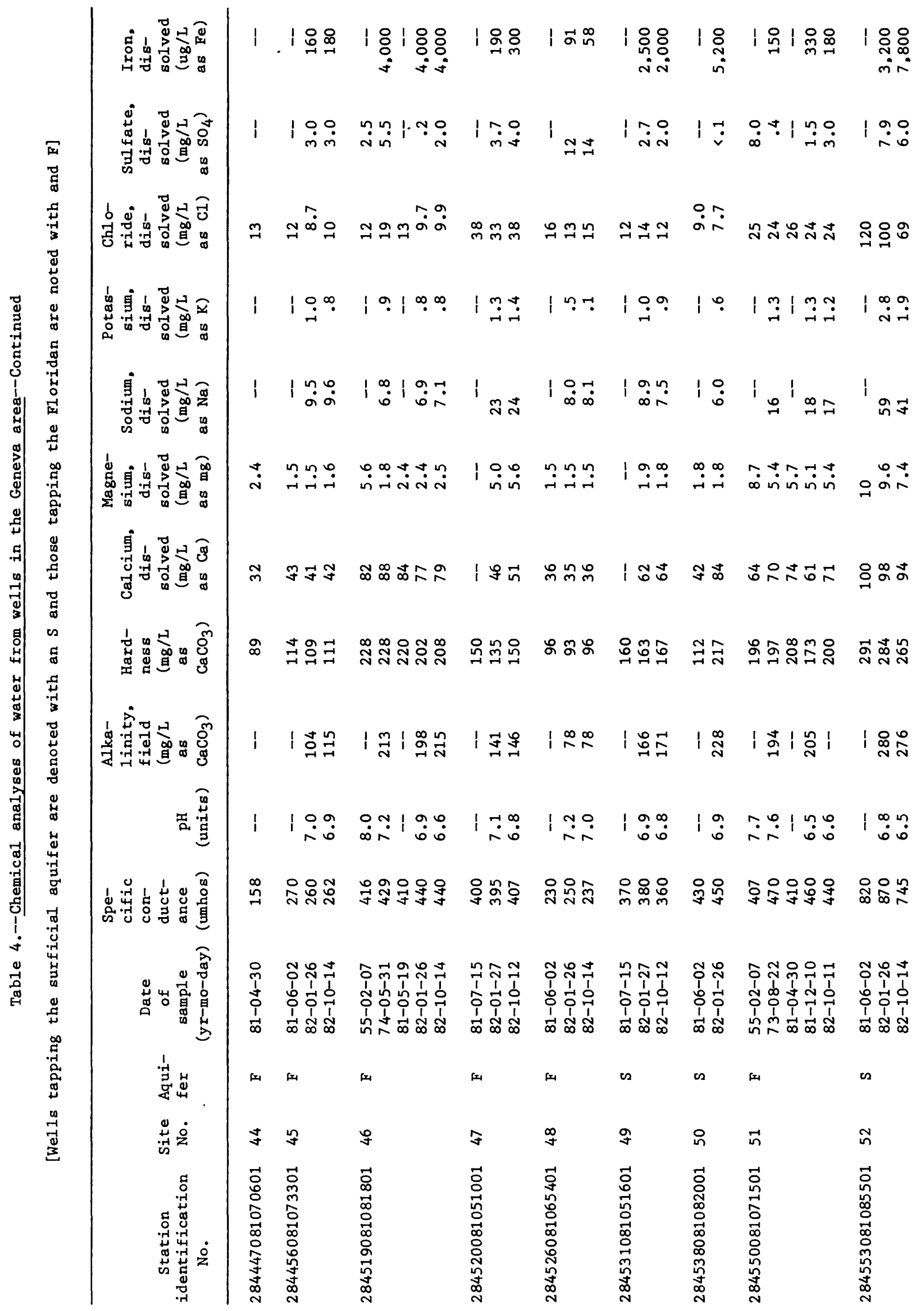




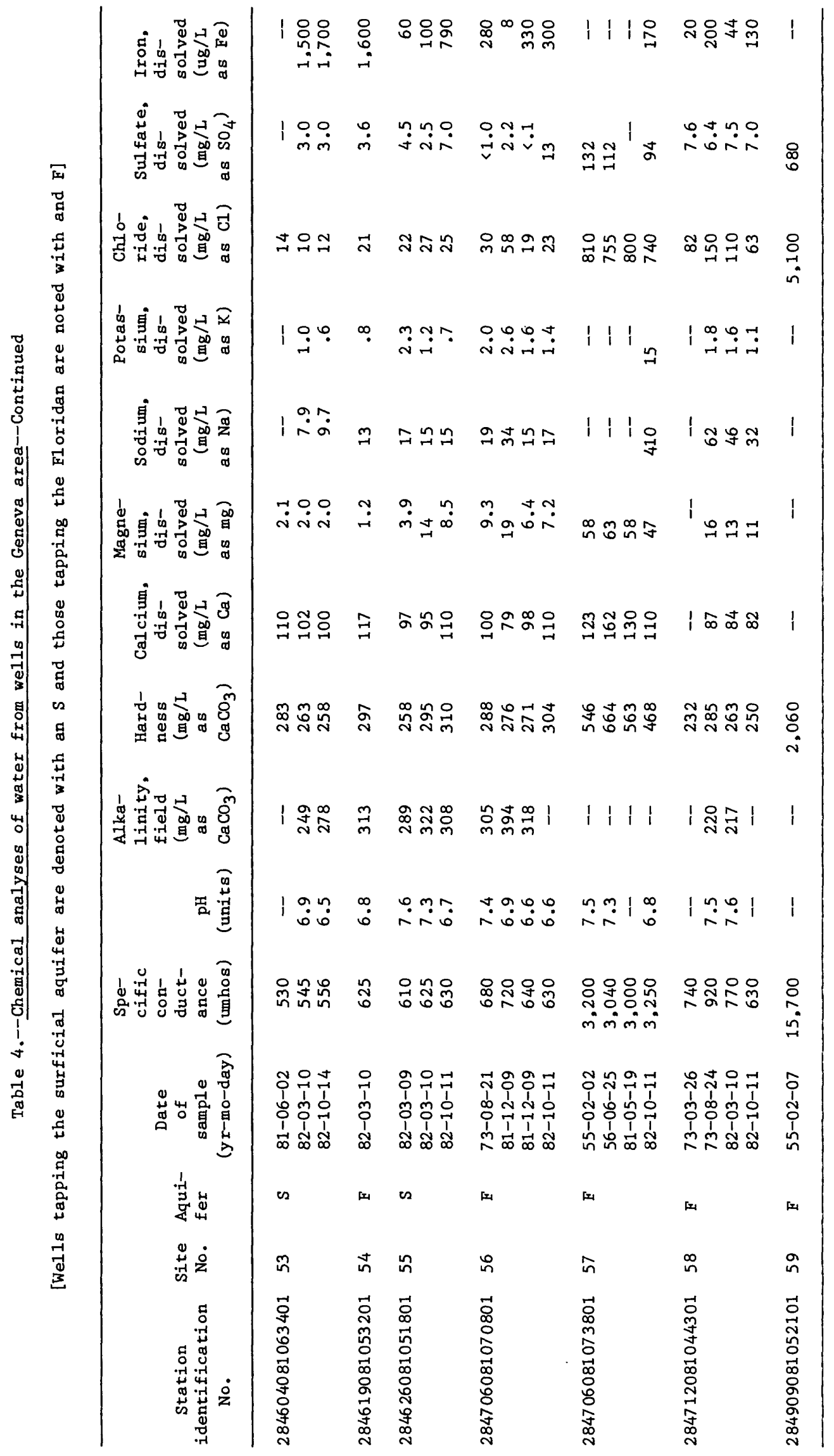




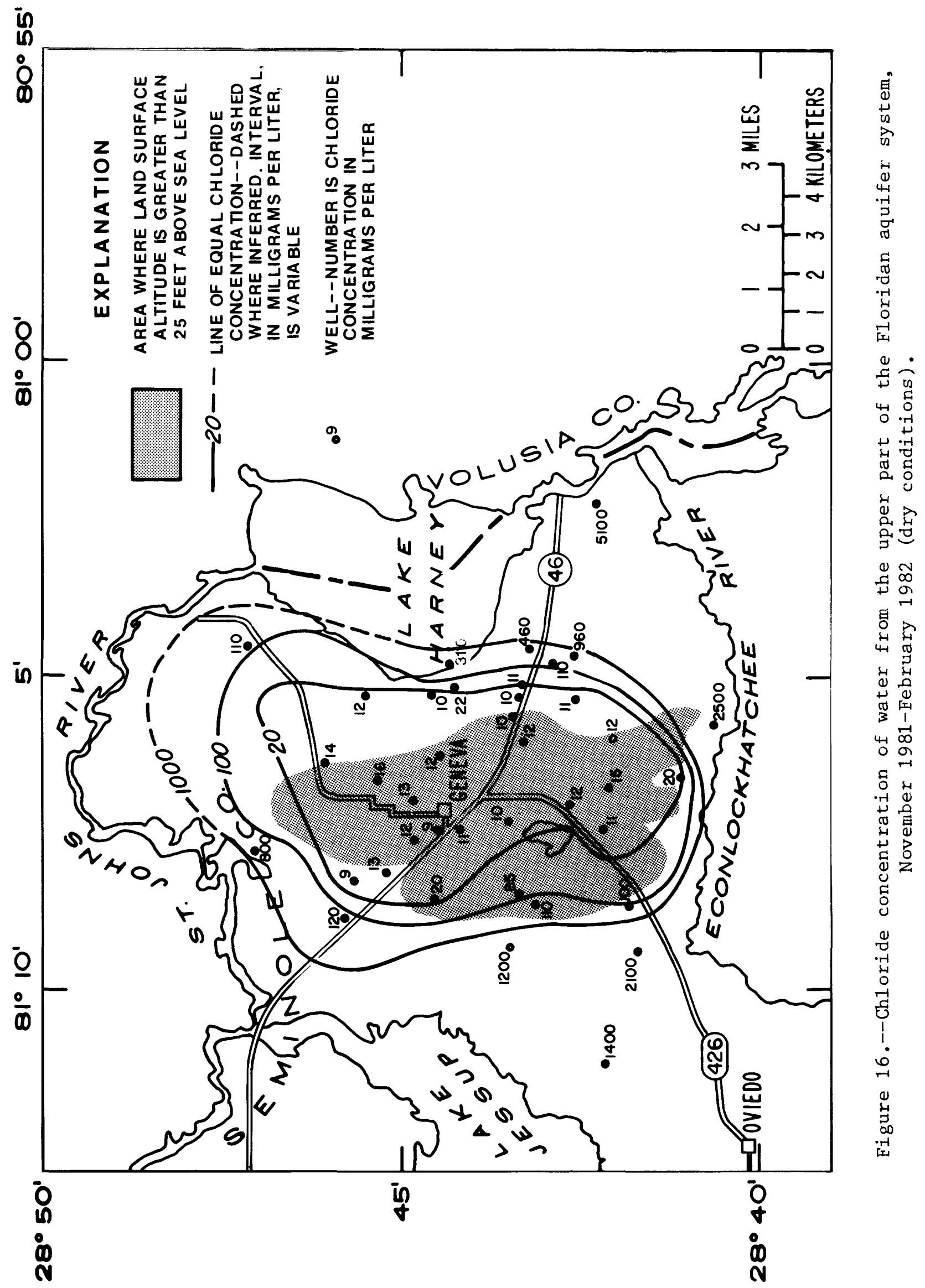




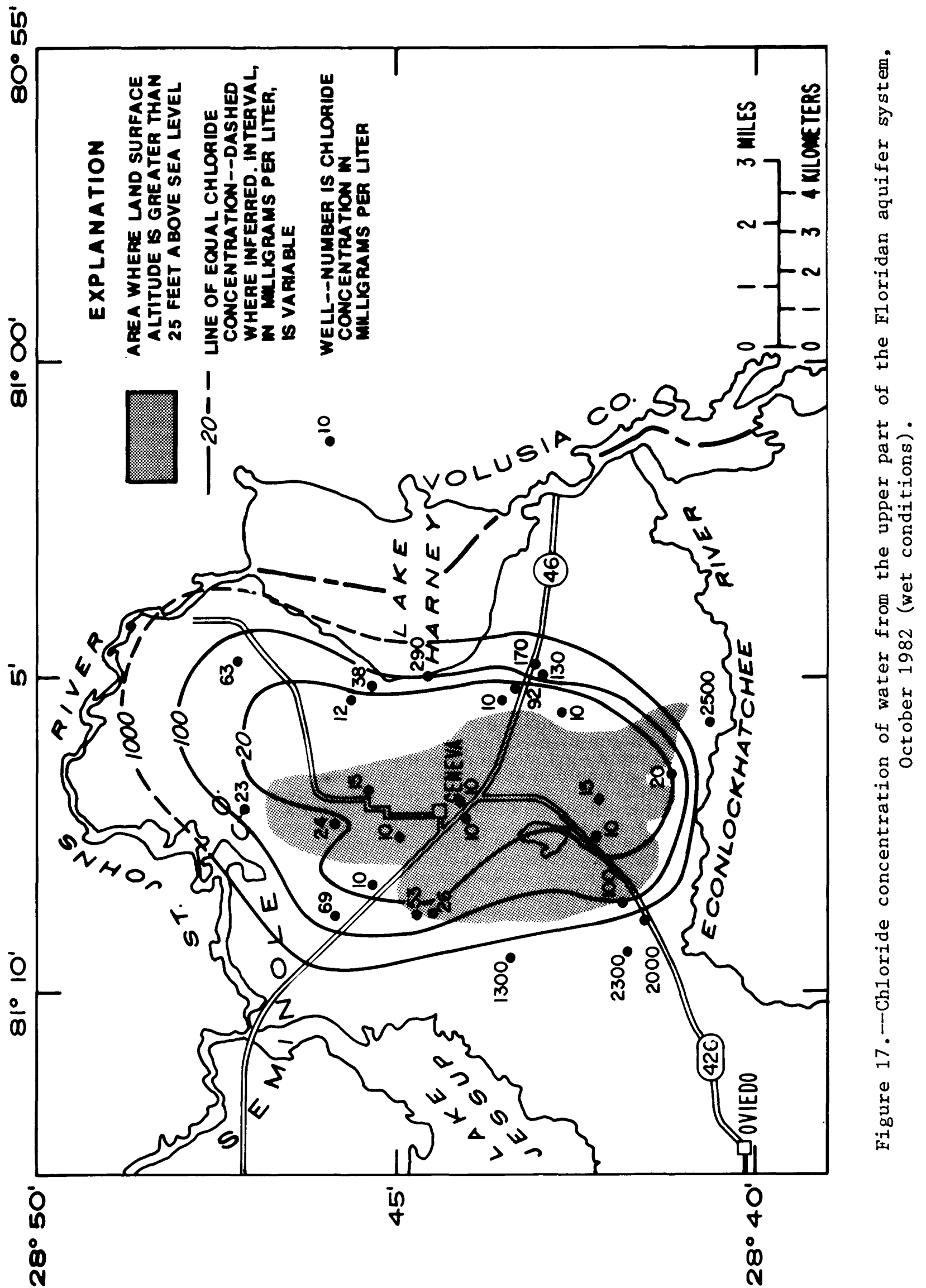


The increase in chloride concentration with depth was documented in several wells. For example, a sample obtained from pumping the entire open-hole section of the well at site 56 in December 1981 had a chloride concentration of $19 \mathrm{mg} / \mathrm{L}$, but a thief sample from the bottom of the well immediately after pumping had a chloride concentration of $58 \mathrm{mg} / \mathrm{L}$. The bottom sample was also silty and colored milky white because of suspended limestone particles. These facts imply that most of the water at well site 56 was coming from the upper part of the open hole and very little from the lower part where the chloride concentration was higher.

Increasing chloride concentrations with depth was also documented by comparing wells at sites 37 (90 feet deep) and 41 (160 feet deep) which had chloride concentrations of $26 \mathrm{mg} / \mathrm{L}$ and $65 \mathrm{mg} / \mathrm{L}$, respectively, in October 1982 . Considering differences in 1 and-surface altitude, the we11 at site 41 penetrates about 60 feet deeper into the Floridan aquifer system than the we11 at site 37.

The 400-foot deep test well at site 36 showed a significant increase in chloride concentration with depth (table 5). Chloride concentration increased sharply from $63 \mathrm{mg} / \mathrm{L}$ at 345 feet to $930 \mathrm{mg} / \mathrm{L}$ at 393 feet. Site 36 is near the center of the recharge area and the thickness of freshwater at that site (about 350 feet) is probably the maximum for the freshwater 1ens. Figures 13, 14, and 15 show the approximate extent of the freshwater lens on the geohydrologic sections $A-A^{\prime}, B-B^{\prime}$, and $C-C^{\prime}$. The interface between freshwater and brackish water is very sharp both horizontally and vertically.

Tab1e 5.--Selected water-quality data for we11 284428081072601 (site 36)

[Concentrations are in milligrams per liter and are dissolved, unless otherwise noted]

\begin{tabular}{lcccc}
\hline & \multicolumn{4}{c}{ Depth below 1 and surface, in feet } \\
\cline { 2 - 5 } & 207 & 290 & 345 & 393 \\
\hline & & & & \\
Bromide (ug/L as Br) & -- & 0 & 0.4 & 5.6 \\
Calcium (as Ca) & 34 & 34 & 34 & 100 \\
Chloride (as C1) & 8.7 & 9.0 & 63 & 930 \\
Magnesium (as Mg) & 1.5 & 3.8 & 7.3 & 61 \\
Potassium (as K) & .8 & .8 & 3.2 & 8.5 \\
Sodium (as Na) & 6.5 & 6.70 & 38 & 410 \\
Specific conductance (umhos/cm) & 210 & 214 & 406 & 3.200 \\
Strontium (ug/L as Sr) & 480 & 620 & 2.000 & 15.000 \\
Sulfate (as SO4) & 2.7 & 2.3 & 9.8 & 62 \\
& & & & \\
\hline
\end{tabular}


Iron concentrations are also of interest because high concentrations can cause staining of plumbing fixtures and an unpleasant taste. The source of iron in the ground water is iron-rich minerals in the sand of the post-Miocene to Holocene deposits. As water seeps slowly downward through the sand, the ironbearing minerals are dissolved. Iron concentrations are generally lower in water from the Floridan aquifer system than from the surficial aquifer, but paradoxically, some of the highest iron concentrations are found in wells that tap the top of the limestone. The top of the Ocala Limestone is an erosional surface, so a buried ancient soil at the top of the Ocala could result in a zone of sediments high in iron. Also, the corrosive effect of water on the iron casings for a long period of time may cause the iron concentrations of water from older wells to be higher than water from newer wells. Relatively deeper wells in the Floridan have lower iron concentrations than either surficial wells or shallow wells in the Floridan. Iron concentrations of wells that tap the Floridan aquifer system and the surficial aquifer are included in table 3.

Figure 18 shows sulfate $\left(\mathrm{SO}_{4}\right)$ concentrations of water from the upper part of the Floridan aquifer system. Concentrations range from 1 ess than $1 \mathrm{mg} / \mathrm{L}$ in the freshwater lens to $800 \mathrm{mg} / \mathrm{L}$ outside the lens. A source of sulfate in the ground water in the Geneva area is Pleistocene seawater which has been slowly flushed from the aquifer. The sulfate concentration of modern sea-water is about 2,700 $\mathrm{mg} / \mathrm{L}$ (Parkhurst and others, 1980, table 2) and the ratio of chloride to sulfate in seawater is about 7.33. Thus, for seawater diluted to the point that its chloride concentration is less than $100 \mathrm{mg} / \mathrm{L}$, the sulfate concentration due solely to the initial sulfate in seawater is about $14 \mathrm{mg} / \mathrm{L}$ or less. At sites where the ratio of chloride to sulfate is less than 7.33 another source of sulfate, such as dissolution of gypsum from the aquifer, is apparent. A marked increase in sulfate in the predominant direction of flow (northeast) is not observed, possibly due to the scarcity of gypsum in the aquifer in that direction.

Another sulfur compound in ground water is dissolved hydrogen sulfide gas, which causes the "rotten egg" smell noticed in some water from the Floridan aquifer system. The source is microbial reduction of dissolved sulfate in the aquifer. Hydrogen sulfide gas comes out of solution (degases) quickly when the water is aerated, so it is easily removed from home and public water systems. Rapid degassing makes accurate determination of the dissolved hydrogen sulfide concentration difficult.

The hardness of water depends on the concentration of dissolved bivalent cations such as calcium and magnesium, and is expressed in terms of equivalent milligrams per liter of calcium carbonate. The principal sources of hardness in water from the Floridan are dissolution of limestone, dolomite, and gypsum, and mixing of freshwater with seawater. The hardness of ground water in the Floridan generally increases with the amount of time the water is in contact with calciumor magnesium-rich rocks such as 1imestone or dolomite; thus, in a general way, hardness is an indicator of residence time in the aquifer. Figure 19 shows the hardness of water from both the surficial and Floridan aquifer systems. The lowest hardness is found in the center of the recharge area and the highest in the discharge areas. 


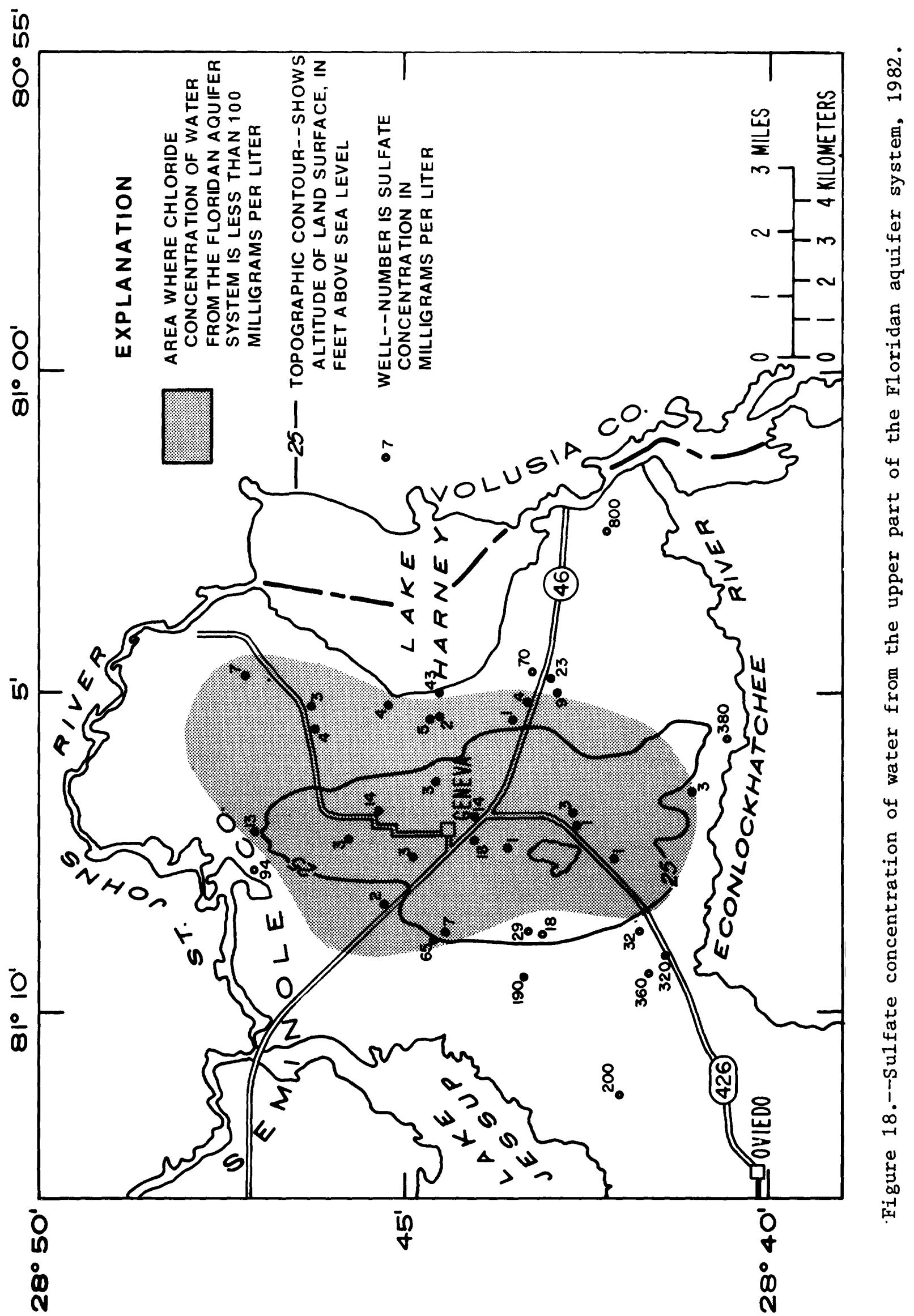




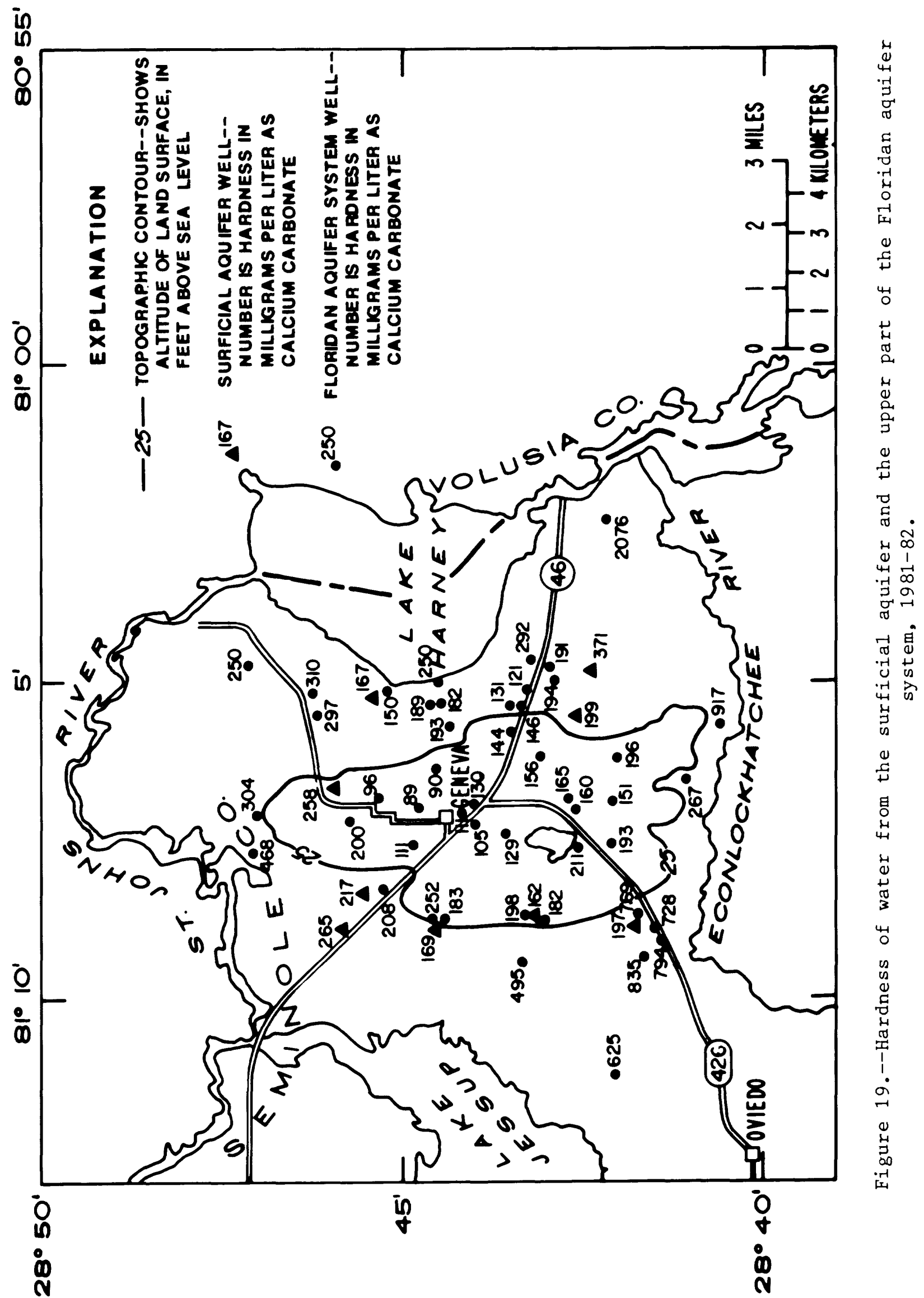




\section{GEOCHEM I CAL EVIDEHCE OF FRESHUATBR-SALTUATER MIXING}

The major constituent concentrations of water from the Geneva area are plotted on a Piper diagram in figure 20. The position of each sample on the plot is in accordance with the relative proportions of the major chemical components of the sample. The mixing of a calcium-bicarbonate-type water (recharge water) with a sodium-chloride-type water (presumably seawater trapped in the formation) is indicated by the points in figure 20 that form a band from a calcium-bicarbonatetype water on the left side of the diagram to a sodium-chloride-type on the right side. Plotting the map locations of the various types of water in figure 21 shows that the calcium-bicarbonate-type water is found in the recharge area, mixing-zonetype water on the periphery of the recharge area, and sodium-chloride-type water in areas where no recharge occurs. Mixing-zone-type water also occurs at site 58, which is outside the active recharge area, but downgradient from the recharge area. This results from dispersion of the freshwater along the flow path.

Evidence of vertical as well as lateral mixing of freshwater and brackish water can be seen in figures 20 and 21 . For example, the well at site 37 is 90 feet deep and yields calcium-bicarbonate-type water while the 160-foot deep well at at nearby site 41 produces mixing-zone-type water. Similarly, at sites 6 and 7 , the shallower well produces mixing-zone-type water, while the deeper well produces sodium-chloride-type water.

The mixing of freshwater and seawater was also modeled and compared to water samples collected in the Geneva area. The computer program PHREEQE (Parkhurst and others, 1980) which simulates the mixing of two solutions as well as equilibration of the mixture with solid phases (minerals) was used to simulate the mixing of a seawater solution (assuming seawater during Pleistocene time was similar in chemical composition to that of today) with fresh ground water of the composition found at site 31 . For simplicity, the mixing process was carried out in equilibrium with calcite at a constant temperature of $25^{\circ} \mathrm{C}$ and at atmospheric pressure, although these conditions may not be met during the natural mixing process.

The mixing of various percentages of seawater and freshwater was simulated, ranging from a mixture of 10 percent seawater and 90 percent freshwater to 0.1 percent seawater and 99.9 percent freshwater. Table 6 shows comparisons of major constituent concentrations calculated by the chemical model with samples collected in the Genemva area. Because the chloride ion ( $\mathrm{C1}^{-}$) is conservative (that is, does not react with other ions under the conditions being simulated) chloride concentrations were used to compare the simulated and actual analyses. The table is arranged so that the analyses from wells in Geneva are in columns next to the simulated analysis with a similar chloride concentration. Thus the samples from sites 4, 5, and 6, which are far from the recharge area, resemble a mixture of 10 percent seawater and 90 percent freshwater, while the sample from site 31 resembles a mixture of 0.1 percent seawater and 99.9 percent freshwater. The wells at site 7 (which is shallower than the one at site 6) and site 58 (which is outside the recharge area but downgradient) are similar to a mixture of 0.5 percent seawater and 99.5 freshwater. 


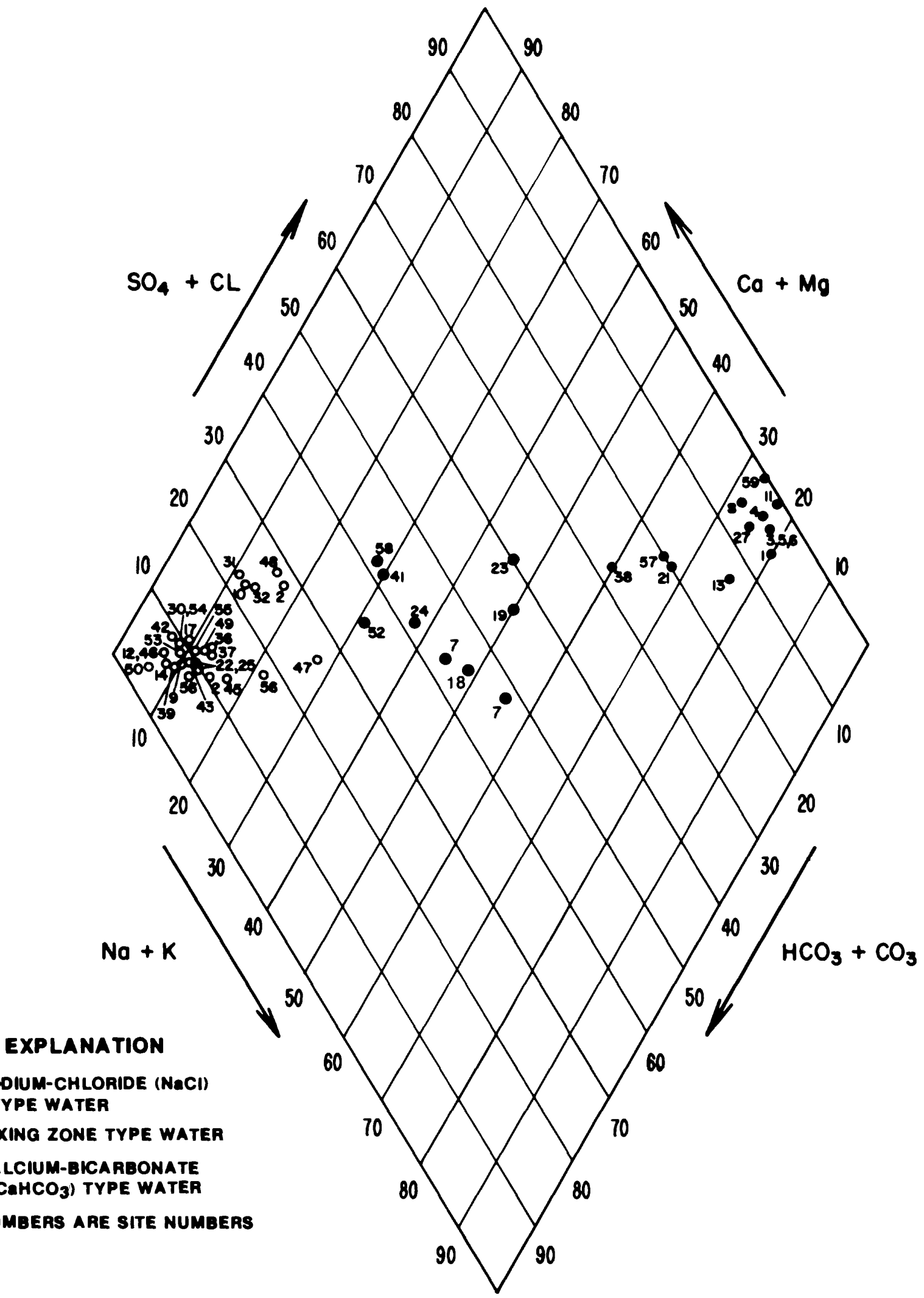

Figure 20.--Piper diagram for water samples from northeast Seminole County, 1981-82. 


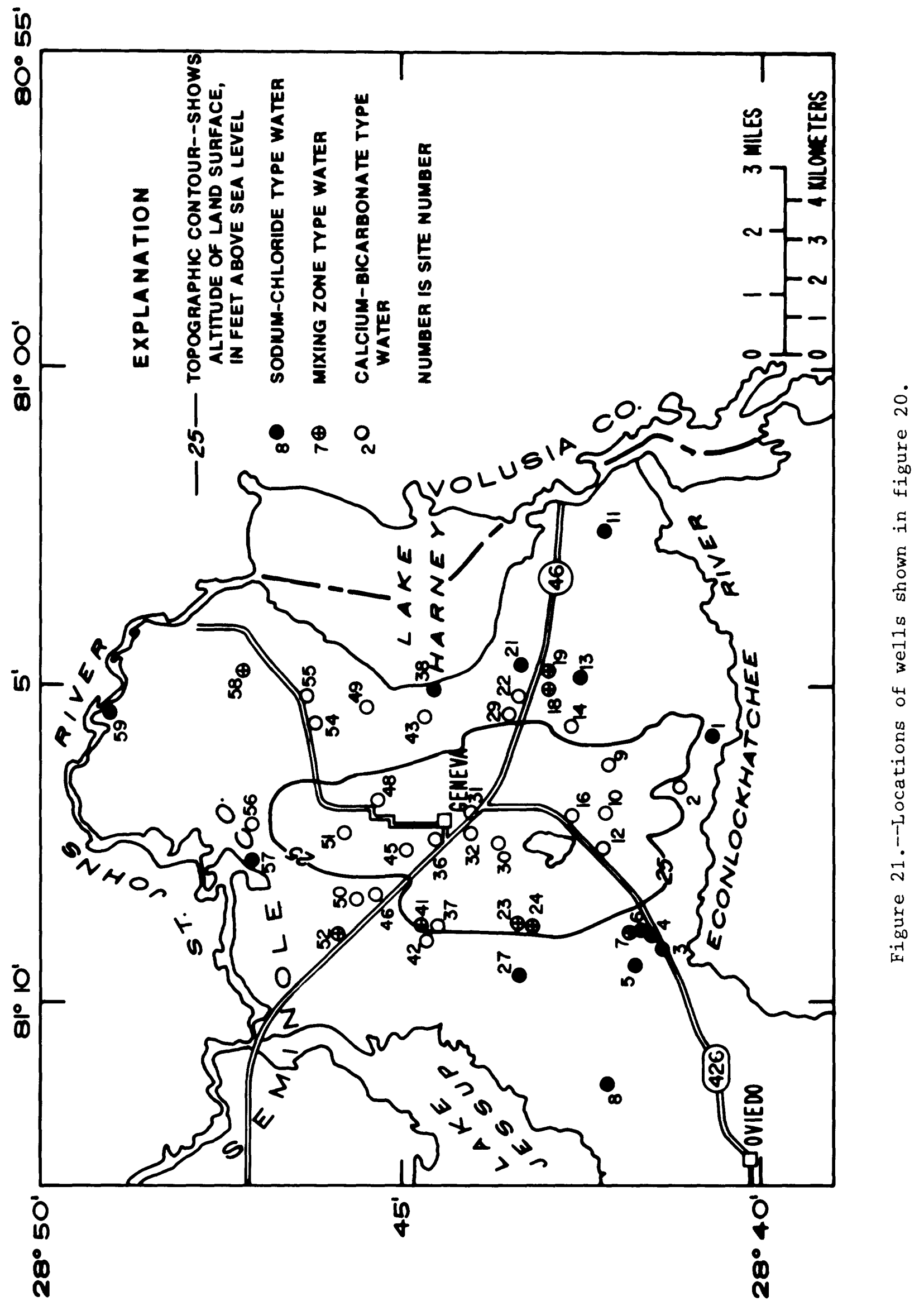




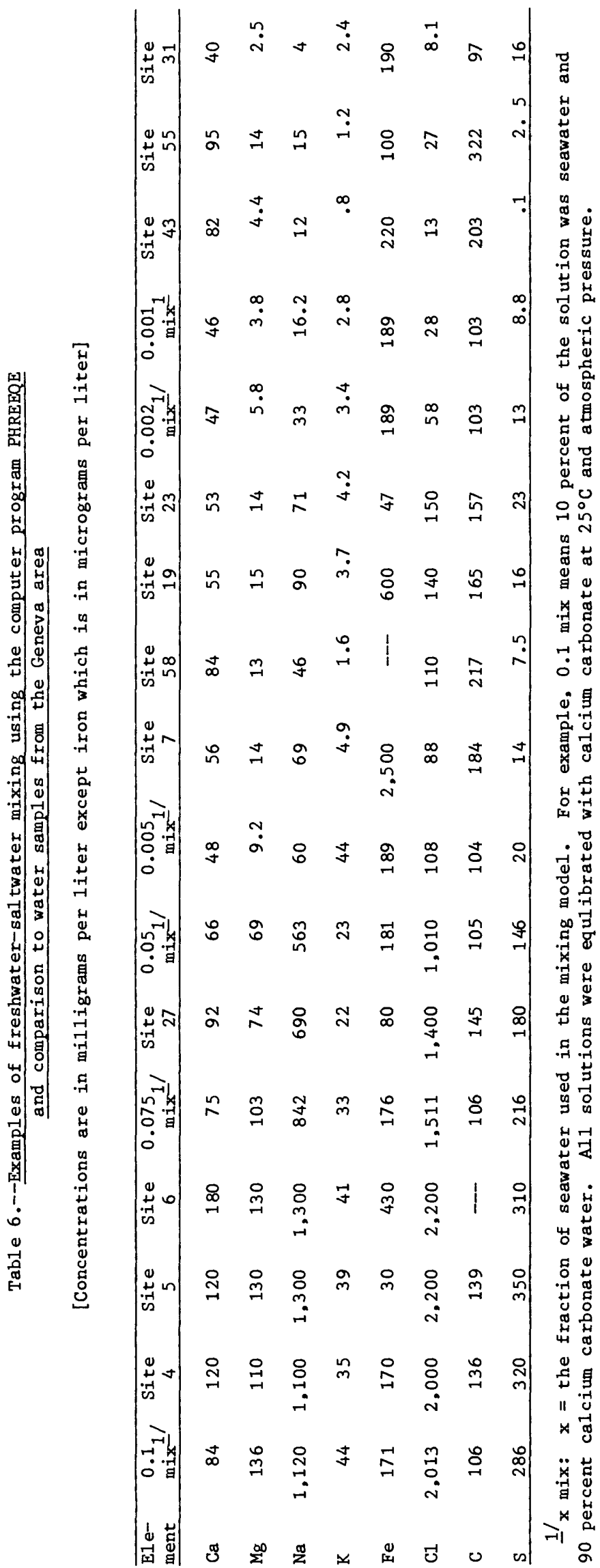


The major difference between the analyses simulated by the model and those of samples collected in Geneva is in the concentrations of calcium and carbon. This is probably because calcite is dissolved as the ground water moves along the flow path. Site 31 at the center of the recharge area is most like the simulated analysis while site 55, far from the center of the recharge area, showed the most excess of calcium and carbon.

Figure 22 shows dilution diagrams for calcium, magnesium, sodium, potassium, and sulfate. In these diagrams, the concentration of the respective ion is plotted versus the chloride concentration of each sample. The curve plotted on each diagram represents the dilution curve for seawater with calcium bicarbonate water derived from the computer simulations using PHREEQE (table 6). The ratios will plot a straight line if no chemical reactions (such as dissolution or precipitation of minerals in an aquifer) are occurring. The plot for sodium versus chloride most clearly shows the dilution of seawater by freshwater with little other chemical activity. Many samples contain more calcium than predicted probably because of the dissolution of gypsum in the aquifer. Many of the potassium values plot below the dilution curve. This suggests that some potassium has been 1ost from the mixture of freshwater and seawater in the aquifer.

The high strontium concentration in the bottom zone of the deep test well at site 36 (table 5) is one piece of evidence that seems contrary to the flushing hypothesis. The concentration of $15 \mathrm{mg} / \mathrm{L}$ is almost twice the concentration in modern seawater. The source of the strontium is most likely not simple dilution of seawater (or even concentrated seawater) but dissolution of dolomite in the aquifer. High strontium concentrations of dolomite in rocks in Texas have been reported (Behrens and Land, 1972), and Sarver (1978) reported strontium concentrations up to 288 parts per million in Eocene dolomites of west-central Florida. A detailed analysis of the strontium problem is beyond the scope of this investigation. 

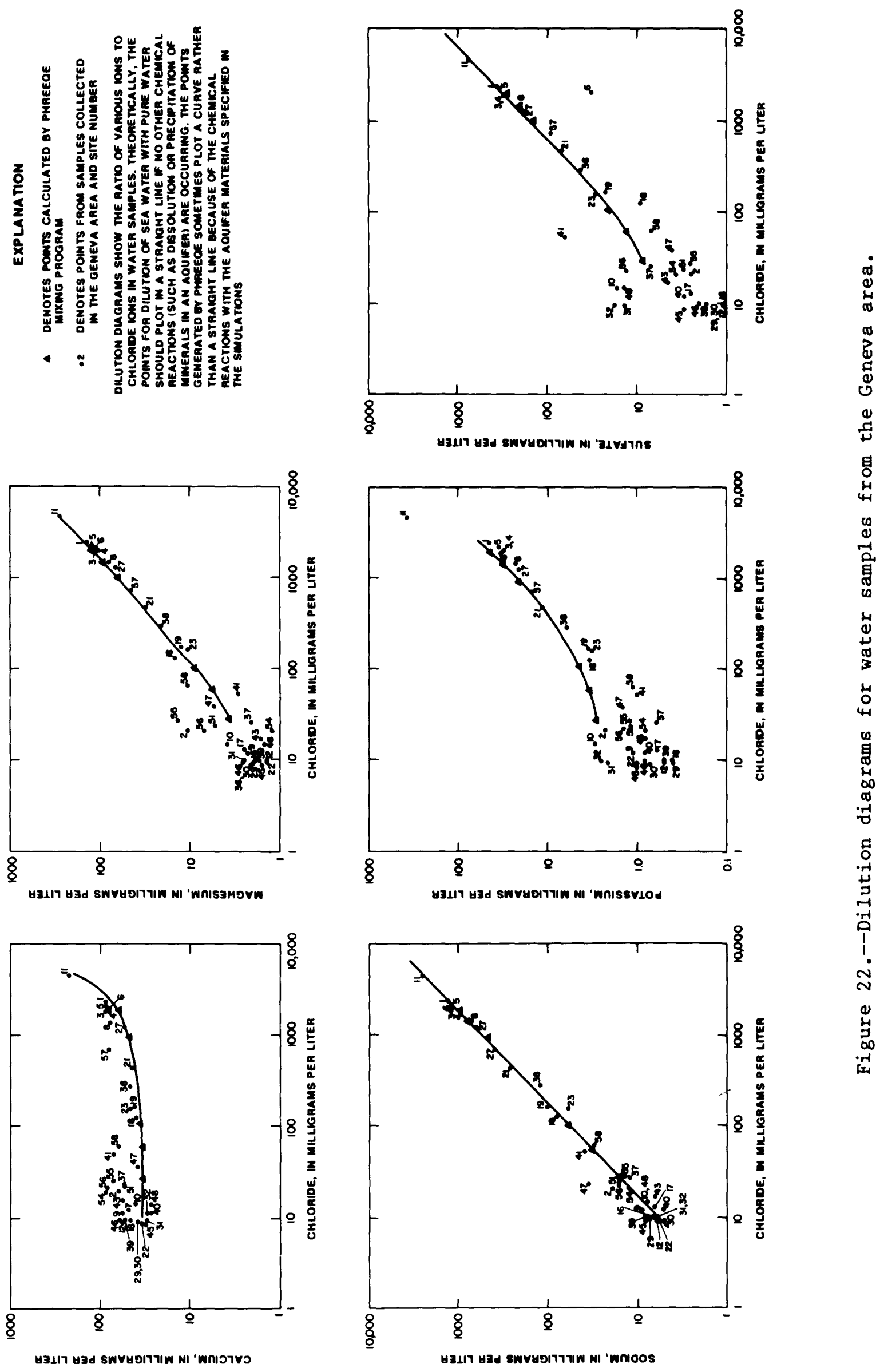


\section{DATBR BUDGBT}

\section{The Water Budget Equation}

Water budgets were calculated to estimate the amount of water recharging ground water in the Geneva area. The water budget equation is based on the principle of conservation of mass: the total input of water must equal total output. The surficial and Floridan aquifer systems must be considered separately.

The equation for the surficial aquifer can be stated as:

$$
\mathrm{P}+\mathrm{R}=\mathrm{ET}+\mathrm{Ru}+\mathrm{Pu}+\mathrm{GO}_{\mathrm{s}}+\Delta \mathrm{S}_{\mathrm{s}}+\mathrm{Re}
$$

where

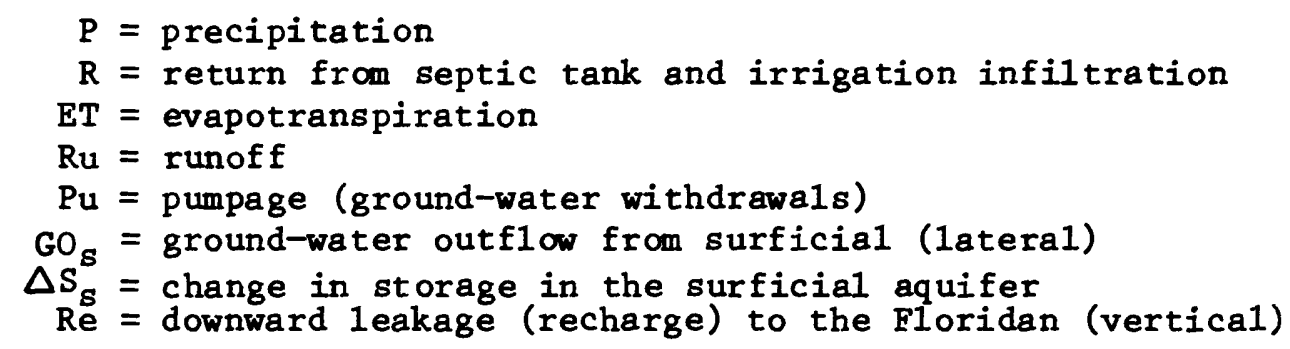

Recharge available to the Floridan (Re) then can be estimated as the residual of the equation.

The equation for the upper part of the Floridan aquifer system within the area bounded by the 25-foot altitude contour is:

$$
\mathrm{Re}+\mathrm{GI}=\mathrm{Pu}+\mathrm{GO}_{\mathrm{F}}+\Delta \mathrm{S}_{\mathrm{F}}
$$

where

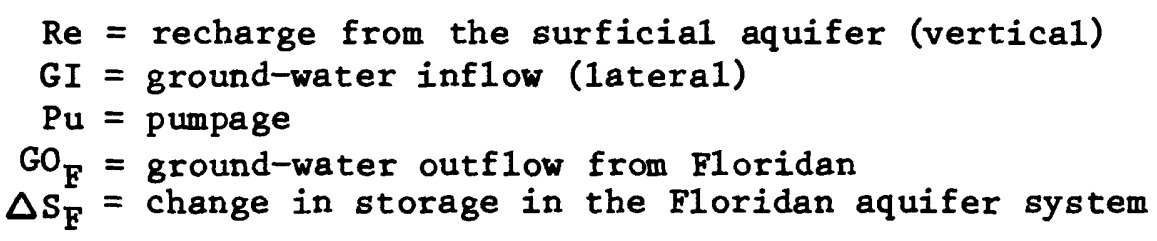

During the study (October 1980 through May 1983), the Geneva area experienced two significantly different hydrologic conditions (drought in 1981 and wetter-than-average conditions in 1982). Three water budgets were calculated to compare extremes with average conditions. During the 1981 drought, rainfal1 at Lake Harney was 41.84 inches, 11.48 inches less than the 30 -year average annual rainfall of 53.32 inches at Sanford. Regression analysis indicated that this event was a 1 out of 10 year drought (that is, the probability of the event occurring would be 10 percent within any given year). In 1982, the rainfall at Lake Harney was 73.06 inches, 19.74 inches more than the 30-year average. A water budget for average conditions was estimated from hydrologic data for 30 years of record (1941 through 1970) at Sanford. Figure 8 is a hydrograph of monthly rainfall at Lake Harney for 1981 and 1982. 
Recharge estimates calculated for the three water budgets were based on the area within the 25-foot altitude contour. In some areas of lower topography the hydraulic gradient is upward (discharge areas) while in other areas (particularly to the north and northeast of Geneva) the gradient is downward, but the head difference between the surficial and Floridan aquifers is so slight that little recharge can take place. In other areas, such as site 55 , the vertical hydraulic gradient changes direction seasonally. Therefore, for the purpose of this analysis the "recharge area" is assumed to be the area inside the 25-foot altitude contour (fig. 1).

\section{Estimating Evapotranspiration}

Evapotranspiration is a term applied to the combined processes of evaporation of water from land and water surfaces and transpiration by plants. Evapotranspiration is the largest component of the water budget and also the most difficult to measure. It is important to differentiate between potential evapotranspiration (PET) and actual evapotranspiration (ET). PET is an estimate or calculation of the maximum amount of water that can be evapotranspired under specified conditions of land use, stage of plant growth and weather conditions. A limitation of most methods for estimating PET is the orientation towards the agricultural aspects of the problem; the amount of water that should be applied to various crops for optimum growth is calculated rather than the actual amount of water consumed by the plants under various conditions. Actual ET is always less than or equal to PET and is usually less than PET. Most methods for measuring actual ET are done under laboratory conditions so results extrapolated to field conditions may not be reliable. Measurements of actual ET in the field can be very time consuming and subject to error. Therefore, calculations of PET are often used to estimate actual ET in water budgets.

Some estimates of evaporation, PET and actual ET for central Florida are as follows:

\section{Source and variable estimated}

U.S. National Oceanic and Atmospheric Administration 1981 and 1982, Pan evaporation at Lisbon, Florida

Farnsworth and others, 1982, Average annual shallow lake free water surface evaporation

G. H. Hughes, U.S. Geological Survey, written commun., 1976. Areal average evapotranspiration for central Peninsular F1orida

Florida Department of Natural Resources; 1970, p. 182, 30-year average consumptive use for citrus in central Florida

Smajstrla and Clark, 1982a, Potential evapotranspiration for Daytona Beach, Florida

Smajstrla and Clark, 1982b, Potential evapotranspiration for Orlando, Florida

Visher and Hughes, 1969, Average annual lake evaporation in east-central Florida
Value in inches per year

59.64 (1981)

$53.44(1982)$

48.00

42.00

47.59

50.56

53.72

48.00 
PET was estimated for the Geneva area using the modified Blaney-Criddle equation. This method of estimation presumes that the amount of water consumed by vegetation during the normal growing season is closely correlated with monthly temperatures, mean monthly percent of daytime hours, and monthly vegetative growth coefficients (which vary depending on the stage of growth of the crop). Stephens and Stewart (1963, p. 126) showed that the reliability of the BlaneyCriddle method is improved by including the cosine of the Sun's zenith angle to compensate for the lower power of the Sun's rays during late fall, winter, and early spring months. Critics of the method suggest that it overestimates PET because it does not take into account humidity, wind speed, water availability, and soil water holding capacity. Often such detailed climatological data are not available. In this analysis, it was assumed that soil moisture did not change (Walton, 1962, p. 23).

Consumptive use was weighted by land use. Land use for the Geneva area was determined from U.S. Geological Survey topographic quadrangle maps and areal photos flown in April 1980 by the Florida Department of Transportation. Verifications were made by ground reconnaissance. For the 1981 water budget, 75 percent of the study area was assumed to be covered by pasture and 25 percent by citrus or woodlands. In 1982, abundant rainfall resulted in the occurrence of areas of open water and swamp, so the land cover was: 58 percent pasture, 25 percent citrus and woodland, and 17 percent swamp. Land-cover percentages for the 30-year average budget were assumed to be the same as for 1982. No published data for consumptive use coefficients of swamp vegetation could be found so the pan evaporation coefficient was used.

Table 7 shows the monthly PET values calculated for the Geneva area for 1981, 1982 and 30-year average conditions using the modified Blaney-Criddle method. Total PET for 1981 was 47.71 inches, for 198257.68 inches, and for 30-year average conditions, 48.70 inches. The increase in PET from 1981 through 1982 can be explained partly by slightly higher than average temperatures in 1982 (table 7) and the increased evapotranspiration from swamp and lake areas that were dry in 1981 .

Actual ET was estimated from PET as follows: The ratio of the estimated actual ET for average annual conditions to the 30-year average Blaney-Criddle PET was calculated, and it was assumed that in any given year, the ratio of actual ET to PET will be the same as the ratio of the long-term average values. Estimated actual ET for average annual conditions is 42 inches (G. H. Hughes, written commun., 1976), PET calculated using the Blaney-Criddle method for 30-year average conditions is 48.70 inches, and the ratio is 0.857 . Thus, actual ET estimated for the water-budget calculation was 86 percent of the Blaney-Criddle PET or 41.03 inches for 1981 and 49.60 for 1982 .

\section{Runoff and Infiltration}

The Geneva area does not have any perennial streams that enable gaging of discharge. However, runoff was calculated in Geneva for each individual storm in 1981 and 1982 using the soil cover complex method as outlined by the U.S. Soil Conservation Service (1975). The method allows calculation of direct surface runoff based on storm rainfall and the soil type and land use of the area. The soil in the Geneva recharge area is sandy and very well drained, whereas in the low-lying surrounding area, the soil is clayey and poorly drained (U.S. Soil Conservation Service, 1966). 
Table 7.--Monthly potential evapotranspiration (PET) for the Geneva area for 1981, 1982, and thirty-year average climatic conditions using the modified Blaney Criddle method

\begin{tabular}{|c|c|c|c|c|c|c|}
\hline Month & $\begin{array}{l}\text { Thirty- } \\
\text { year } \\
\text { average } \\
\text { monthly } \\
\text { temperature } \\
\left({ }^{\circ} \mathrm{F}\right)\end{array}$ & $\begin{array}{l}1981 \\
\text { Tem- } \\
\text { per- } \\
\text { ature } \\
\left({ }^{\circ} \mathrm{F}\right)\end{array}$ & $\begin{array}{l}1982 \\
\text { Tem- } \\
\text { per- } \\
\text { ature } \\
\left({ }^{\circ} \mathrm{F}\right)\end{array}$ & $\begin{array}{l}\text { Potential } \\
\text { Thirty- } \\
\text { year } \\
\text { average } \\
\text { monthly } \\
\text { PET }\end{array}$ & $\begin{array}{l}\text { evapotra } \\
1981 \\
\text { Month1y } \\
\text { PET }\end{array}$ & $\begin{array}{l}\text { spiration } \\
1982 \\
\text { Month1y } \\
\text { PET }\end{array}$ \\
\hline $\begin{array}{l}\text { Jan } \\
\text { Feb } \\
\text { Mar } \\
\text { Apr } \\
\text { May } \\
\text { June } \\
\text { July } \\
\text { Aug } \\
\text { Sept } \\
\text { Oct } \\
\text { Nov } \\
\text { Dec }\end{array}$ & $\begin{array}{l}59.23 \\
60.87 \\
65.88 \\
71.24 \\
76.17 \\
80.21 \\
81.98 \\
81.86 \\
80.05 \\
73.95 \\
66.70 \\
61.28\end{array}$ & $\begin{array}{l}50.3 \\
59.8 \\
61.8 \\
71.4 \\
74.8 \\
82.8 \\
83.1 \\
82.2 \\
78.0 \\
74.3 \\
63.5 \\
57.5\end{array}$ & $\begin{array}{l}57.1 \\
66.7 \\
68.3 \\
71.6 \\
73.5 \\
81.1 \\
82.2 \\
81.8 \\
79.4 \\
72.5 \\
71.4 \\
65.8\end{array}$ & $\begin{array}{l}1.263 \\
1.696 \\
2.929 \\
4.383 \\
5.982 \\
6.945 \\
7.244 \\
6.611 \\
4.913 \\
3.491 \\
1.930 \\
1.311 \\
\end{array}$ & $\begin{array}{l}0.868 \\
1.424 \\
2.545 \\
4.302 \\
5.908 \\
7.114 \\
7.538 \\
6.801 \\
5.065 \\
3.432 \\
1.676 \\
1.038 \\
\end{array}$ & $\begin{array}{l}1.614 \\
2.442 \\
3.914 \\
5.608 \\
7.368 \\
8.964 \\
9.176 \\
6.607 \\
5.093 \\
3.423 \\
2.069 \\
1.406 \\
\end{array}$ \\
\hline \multicolumn{3}{|c|}{ Total } & & 48.70 & 47.71 & 57.68 \\
\hline
\end{tabular}

Total runoff calculated for individual storms in 1981 was 0.3 inches. During 1982, April and June had individual storms producing large amounts of rain. A storm in April produced more than 12 inches of rain in 1 day, followed by 2 inches the next day. About 6 inches of runoff were calculated for that storm. In June, one storm produced about 7 inches of rain, followed by 2.4 inches the next day. About 4 inches of runoff was calculated for those storms. Most of the runoff was generated from the poorly drained soils along the periphery of the assumed boundary of the recharge area. Within the recharge area, runoff was minimal for the two large storms mentioned and the runoff that was generated drained into existing lakes or physiographic depressions and was, thus, available for recharge and evaporation. Thus, for these water budgets, runoff was assumed to be negligible.

Infiltration from septic tanks and irrigation water must be considered as recharge to the surficial aquifer. All the pumpage from the two public-supply systems in the area is exported from the Geneva area and, thus, is not returned to the system. Assuming that 70 percent of the pumpage from individual domestic wel1s is returned, and 30 percent of the pumpage from irrigation wells is returned, the total return infiltration is about $0.15 \mathrm{Mgal} / \mathrm{d}$ or $0.12 \mathrm{in} / \mathrm{yr}$, a negligible amount. 


\section{Changes in Ground-Water Storage}

Change in ground-water storage represents the volume of water either taken into or released from storage in the surficial aquifer and the Floridan. Change in storage is calculated by multiplying the head change over a given time period by the storage coefficient of the aquifer.

For unconfined aquifers, the storage coefficient is virtually the same as the specific yield (Lohman, 1972, p. 8). Based on dry sieve analysis, the specific yield of the surficial sand was estimated at 0.2 . Surficial aquifer test wells drilled in early 1982 showed that fluctuations of surficial aquifer water levels were similar to those of surface-water bodies. Based on the staff gage located on Buck Lake, the average net water level decline in the surficial aquifer in 1982 was estimated to be 2.0 feet. In 1982, water 1 evels rose about 4 feet. Thus, the change in storage for the surficial aquifer for 1981 was $(-2 \mathrm{feet})(12 \mathrm{in} / \mathrm{ft})(0.20)=-4.8 \mathrm{inches}$ and for $1982(4 \mathrm{feet})(12 \mathrm{in} / \mathrm{ft})(0.20)$ $=9.6$ inches. Change in storage in surface-water bodies was estimated to be 0.09 inch for 1981 and 0.18 inch for 1982. Thus, the change in storage totals are -4.89 inches for 1981 and 9.78 inches for 1982 .

Change in storage in the Floridan is calculated by multiplying the head change over a given time period by the storage coefficient of the aquifer. The storage coefficient for the Floridan aquifer system was estimated to be 0.002 based on Lohman's (1972, p. 9) discussion of storage properties of confined aquifers. Average head change in the Floridan aquifer system in the Geneva area from September 1980 through September 1981 was 2.0 feet. The change in storage in the Floridan was about 0.05 inch and is, thus, negligible.

In 1982, the head change in the upper part of the Floridan was about 5 feet, resulting in a calculated 0.12 inch of water taken into storage in the Floridan, which is negligible.

For the 30-year average water budget, it was assumed that there were no changes in ground-water storage for the surficial aquifer and the Floridan (Walton, 1962, p. 23).

\section{Ground-Water Outflow}

Ground-water outf1ow from the surficial aquifer was assumed to be the same for all three water budgets and was calculated using Darcy's Law. The lateral hydraulic gradient between the surficial aquifer wells at sites 17 and 27 was $4.1 \mathrm{ft} / \mathrm{mil}$ e. Transmissivity was estimated to be $1,000 \mathrm{ft}^{2} / \mathrm{d}$ based on several tests of the surficial aquifer in central Florida which showed transmissivity values ranging from 400 to $2,000 \mathrm{ft}^{2} / \mathrm{d}$ (P1anert and Aucott, 1985 , p. 20-23, and E. R. German, U.S. Geologica1 Survey, ora1 commun., 1985). Ca1culated outflow for the surficial aquifer was thus, about $500,000 \mathrm{gal} / \mathrm{d}$ or $0.5 \mathrm{in} / \mathrm{yr}$. There is no inflow to the surficial from outside the recharge area. 
Ground-water outflow from the Floridan was calculated as the residual of the water budget equation for the Floridan aquifer system. Based on the potentiometric surface maps (fig. 10) and maps of chloride concentration (figs. 16 and 17) outflow from the recharge area is to the northeast. There is no inflow to the freshwater lens from outside the recharge area, based on the stability of the position of the fresh-brackish water interface. It is assumed that all of the outflow is thus derived from recharge in the Geneva area.

\section{Ground-Water Withdrawals}

Most of the ground-water withdrawals in the Geneva area are for domestic supply and agricultural uses. Two public supply well fields in the Geneva area supply water to users on the periphery of Geneva around Lake Harney and Mullet Lake, where fresh ground water is not available. There is no industrial use of ground water in Geneva.

Table 8 shows estimated water use for 1982 (Marel1a, 1983). Eighty-nine percent of total agricultural pumpage is for pasture, which includes water use for nurseries and livestock watering. Eleven percent is for citrus irrigation. In 1980, Lake Harney Water Association. Inc. had 121 service units and pumped about $32,000 \mathrm{gal} / \mathrm{d}$. Mullet Lake Water Association, Inc., had 144 service units and pumped about $26,000 \mathrm{gal} / \mathrm{d}$.

Tab1e 8.--Estimated pumpage in the Geneva area in 1981

\begin{tabular}{ccc}
\hline Domestic & Population & Pumpage (Mgal/d) \\
\hline $\begin{array}{l}\text { Lake Harney Water } \\
\text { Association, Inc. }\end{array}$ & 314 & 0.03 \\
$\begin{array}{l}\text { Mullett Lake Water } \\
\text { Association, Inc. }\end{array}$ & 400 & .02 \\
Individual wells & 2.361 & .18 \\
$\quad$ Agriculture & $\underline{(\text { Acre-ft/d) }}$ & \\
Pasture & 0.58 & .19 \\
Citrus & .06 & .02 \\
Total & & 0.44 \\
\hline
\end{tabular}

Data from Marella, 1983. 
For the purpose of water-budget calculations, all domestic wells were assumed to pump from the Floridan aquifer. A few wells that tap the surficial aquifer are used for lawn and garden irrigation but the withdrawals from such wells were negligible. Domestic use from individual wells was calculated by multiplying the estimated population by $75 \mathrm{gal} / \mathrm{d}$ per person. Total selfsupplied domestic water use in 1982 was, therefore, about $180,000 \mathrm{gal} / \mathrm{d}$.

Total pumpage from the Geneva area for 1982 is estimated at $0.44 \mathrm{Mgal} / \mathrm{d}$ which equals 0.37 inches distributed over the 22-square miles of the freshwater lens. The 1982 withdrawal rates were also used for the 1981 and 30-year average water budgets. This may overestimate withdrawals for long-term conditions somewhat, but withdrawals are still a small component of the budget.

\section{Limitations of the Water Budgets}

Although water budgets can be useful tools, they have 1imitations which must be considered when evaluating the results of the calculations. The main causes of the 1 imitations are the assumptions that are made in conceptualizing the budget problem, and the inaccuracies that arise in estimating components of the budget.

Some of the assumptions which could have significant effects on the calculations are:

(1) that the recharge area is the area inside the 25-foot altitude contour.

(2) that there is no runoff from the recharge area,

(3) that all pumpage is from the Floridan,

(4) that there is no ground-water outflow from the Floridan toward the west.

Inaccuracies can also result because of the difficulty in measuring some of the parameters. For example, the estimates of the storage coefficients for the aquifers could be inaccurate and thus, the amount of water taken into or given up from storage incorrect. On the long term, some of the inaccuracies may average out, for example in estimates of ET and runoff; thus, calculations for any particular year are more sensitive to inaccurate estimates of the component8, and therefore, should be used more cautiously than long-term budgets.

\section{Conclusions Based on the Water Budgets}

In the previous sections, the components of the water budget equations (equations 1 and 2) were discussed. Table 9 shows a compilation of the equations for both the surficial aquifer and the Floridan aquifer system. The budget for the surficial aquifer shows that in 19815.2 inches $(5.4 \mathrm{Mgal} / \mathrm{d})$ were available for recharge to the Floridan and outflow from the Floridan was about 4.8 inches (5 $\mathrm{Mgal} / \mathrm{d})$. In $1982,13.2$ inches $(13.8 \mathrm{Mgal} / \mathrm{d})$ were available for recharge to the Floridan and outflow from the Floridan was 12.8 inches $(13.4 \mathrm{Mgal} / \mathrm{d})$. Using the 30-year average climatological data, average recharge available to the Floridan is 10.8 inches $(11.3 \mathrm{Mgal} / \mathrm{d}$ ) and average outflow is 10.4 inches (10.9 Mga1/d). The difference, 0.4 inches, is the water consumed in the Geneva area. 
A flow-net analysis was made to compare the outflow calculated in the water budgets to flows calculated using geohydrologic data and determine if the aquifer can carry the flows calculated in the budgets. Ground-water flow moving along flow lines perpendicular to equipotential contour lines can be calculated using Darcy's Law expressed by the following equation:

$$
\mathrm{Q}=\mathrm{TIL}
$$

where

$$
\begin{aligned}
& \mathrm{Q}=\text { discharge in cubic foot per day } \\
& \mathrm{T}=\text { transmissivity in square foot per day } \\
& \mathrm{I}=\text { average hydraulic gradient across potential in foot per mile } \\
& \mathrm{L}=\text { length of flow channel }
\end{aligned}
$$

In flow net analysis, it is assumed that flow in the aquifer is horizontal and the aquifer is homogenous and isotropic.

Table 9.- Components of the water budgets for 1981, 1982, and thirtyyear average conditions, in inches per year

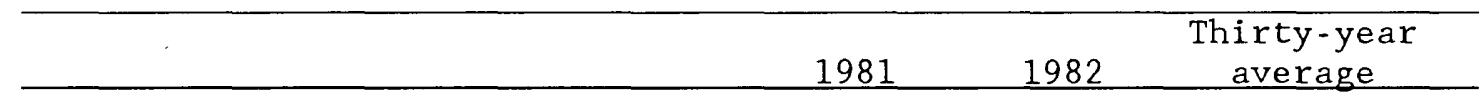

Surficial aquifer

$\begin{array}{lccc}\text { Precipitation } & 41.84 & 73.06 & 53.32 \\ \text { Return infiltration } & 0 & 0 & 0 \\ \text { Evapotranspiration } & 41.03 & 49.60 & 42 \\ \text { Runoff } & 0 & 0 & 0 \\ \text { Withdrawals } & 0 & 0 & 0 \\ \text { Ground-water storage } & .5 & .5 & .5 \\ \text { Change in ground-water storage } & 4.89 & 9.78 & 0 \\ & 5.2 & 13.2 & 10.8\end{array}$

Floridan aquifer system

$\begin{array}{llcc}\text { Recharge available } & 5.2 & 13.2 & 10.8 \\ \text { Ground-water inflow } & 0 & 0 & 0 \\ \text { Withdrawals } & .37 & .37 & .37 \\ \text { Ground-water outflow } & 4.8 & 12.8 & 10.4 \\ \text { Change in ground-water storage } & 0 & 0 & 0\end{array}$


Potentiometric surface maps for September 1981 and September 1982 (fig. 10) were used for the flow net analysis and a range of transmissivity values from $17,000 \mathrm{ft}^{2} / \mathrm{d}$ to $91,000 \mathrm{ft}^{2} / \mathrm{d}$ were used for the calculations. Calculated flows are as follows:

\begin{tabular}{|c|c|c|c|}
\hline Date & Transmissivity & \multicolumn{2}{|c|}{ Ground-water outflow } \\
\hline & $\left(f t^{2} / d\right)$ & $\overline{(\mathrm{Mgal} / \mathrm{d})}$ & $(\mathrm{in} / \mathrm{y} \mathrm{r}$ \\
\hline 1981 & $\begin{array}{l}17,000 \\
65,000 \\
91,000\end{array}$ & $\begin{array}{l}1.24 \\
4.7 \\
6.6\end{array}$ & $\begin{array}{l}1.1 \\
4.5 \\
6.3\end{array}$ \\
\hline 1982 & $\begin{array}{l}17,000 \\
65,000 \\
91,000\end{array}$ & $\begin{array}{r}2.0 \\
7.7 \\
10.8\end{array}$ & $\begin{array}{r}1.9 \\
7.4 \\
10.3\end{array}$ \\
\hline
\end{tabular}

For 1981 the ground-water outflow from the Floridan for a transmissivity of $65,000 \mathrm{ft}^{2} / \mathrm{d}$ compares we11 with the outflow calculated in the water budget, but for 1982 for the same assumed transmissivity, the water budget apparently overestimates the amount of outflow. The discrepancy might be because of errors in estimating evapotranspiration or outflow from the surficial aquifer during the wetter-than-average year.

The average annual outflow from the Geneva freshwater lens is about 10 inches (or about $10 \mathrm{Mgal} / \mathrm{d}$ ). Any reduction in the outflow to less than 10 inches per year will disturb the equilibrium between the freshwater and saltwater and cause a movement of the interface. Because of the large volume of water in the aquifer, a large amount of freshwater needs to be displaced before the movement of the interface is apparent. Thus, although ground-water outflow was reduced to about 5.5 inches in 1981, there was no apparent deterioration of water quality in the freshwater lens. In 1982, abundant rainfall again provided sufficient ground-water outflow to regain the balance between freshwater and saltwater. If ground-water outflow is reduced to less than 10 inches per year for a number of years, noticeable deterioration of water quality will eventually occur. At present, ground-water withdrawals are less than 5 percent of the average annual recharge rate so as yet, there is no discernible movement of the freshwater-saltwater interface. If ground-water development increases in the Geneva area, withdrawal rates should be evaluated continually, depending on precipitation. Monitoring of chloride concentrations of water in wells on the periphery of the lens is also desirable. 


\section{SUMMARY AND CONGL US IONS}

Northeast Seminole County, Fla., contains an isolated recharge area of the Floridan aquifer system that forms a freshwater lens completely surrounded by saline water. The freshwater lens covers an area of about $22 \mathrm{mi} 2$ surrounding the town of Geneva, and generally follows the 25 foot altitude contour. Thickness of the lens is about 350 feet in the center of the recharge area. The hydrologic units, in descending order, consist of the post-Miocene sand and shell of the surficial aquifer: Miocene clay, sandy clay, and shell that form a leaky confining bed; and permeable Eocene limestones of the Floridan aquifer system.

The purpose of the investigation was to delineate the vertical and lateral extent of the freshwater lens and to evaluate recharge potential. To accomplish these objectives, water samples from about 50 wells and geologic and geophysical data from test wells at nine sites were analyzed. Rainfa11, runoff, lake leve1, and ground-water level data were used to estimate water budgets.

The potentiometric surface of the Floridan aquifer system varies about 5 feet seasonally and apparently has not declined significantly since 1964. Lake levels fluctuate with the amount of local rainfall. A long-term decline in lake levels may be occurring: the maximum stage recorded for Lake Geneva during the wetterthan-average year 1982 was 23.05 feet compared to a maximum of 28.2 feet observed by Barraclough (1962b, p. 40) from 1953-56.

Sufficient quantities of water for domestic and sma11 pub1ic supply systems are available from the Floridan aquifer system in the Geneva area. Transmissivity values from specific capacity tests of the upper part of the Floridan range from about 1,700 to $17,000 \mathrm{ft}^{2} / \mathrm{d}$ (Tibbals, 1977, fig. 14). Transmissivity values derived from ground-water flow modeling ranged from 35,000 to $100,000 \mathrm{ft}^{2} / \mathrm{d}$ (Tibbals, 1981, fig. 6), and represent more accurately the transmissivity of the ful1 thickness of the upper part of the aquifer system. The specific capacity of the test well at site 36 ranged from less than 3 [(gal/min)/ft] for the upper part of the Ocala Limestone to about 12 [(gal/min)/ft] for the upper part of the Avon Park Formation.

The limiting factor for water supply in the area is the chemical quality of the water. Chloride concentrations range from 1 ess than $20 \mathrm{mg} / \mathrm{L}$ in the center of the recharge area to about $5,100 \mathrm{mg} / \mathrm{L}$ near the $\mathrm{St}$. Johns River southeast of Geneva. Other constituents analyzed included sulfate (range 1 to $800 \mathrm{mg} / \mathrm{L}$ ), hardness (range 89 to $2,076 \mathrm{mg} / \mathrm{L}$ ), and iron (range 34 to 6,600 ug/L).

Geochemical analyses support the conclusion that the freshwater lens is the result of local rainfall flushing ancient seawater from the Floridan aquifer system. In the higher elevation area near Geneva, the sediments overlying the Floridan aquifer system are very permeable, allowing water from higher stands of sea level to be flushed out by rainfall. In the surrounding $10 \mathrm{w}-1$ ying areas the sediments contain thick clay layers which have slowed flushing of the trapped seawater. 
Because the freshwater lens results entirely from local recharge, the recharge rate is important in estimating long-term sustained freshwater yield of the aquifer in the Geneva area. To estimate recharge, water budgets were calculated for 1981, 1982, and a long-term average using data from 1941 to 1970 . It is estimated that recharge was about 5 inches $(5.4 \mathrm{Mgal} / \mathrm{d})$ in 1981 , a year with much less than normal rainfal1. In 1982, recharge was about 13 inches $(13.8 \mathrm{Mgal} / \mathrm{d})$. Average recharge for 1941-70 was estimated to be about 11 inches (11.3 Mgal/d).

Freshwater that recharges the Floridan aquifer system in the Geneva area is either pumped out or flows north and northeast to discharge in or near the St. Johns River. Average annual outflow is about 10 inches. The reduction of outflow to about 5 inches during the drought of 1981 did not cause detectable movement of the saltwater-freshwater interface because of the large volume of water that must be displaced before a change in water quality can be observed. If ground-water outflow is reduced to less than 10 inches per year over the long term, deterioration of water quality will eventually occur. 


\section{SELECTED REFERENCES}

Back, William, and Hanshaw, B. B, 1971, Geochemical interpretations of ground-water flow systems: Water Resources Bulletin, v. 7, na 5, p. 1008-1016.

Barraclough, I. To, 1962a, Ground-water records of Seminole County, Florida: Florida Gealogical Survey Information Cincular 34, $148 \mathrm{p}$

- 1962b, Ground-water resources of Seminole County, Florida: Florida Geological Survey Report of Investigations 27, $91 \mathrm{p}$, and 10 sheets.

Behrens, E W., and Land, L S., 1972, Subtidal Holocene dolomite, Baffin Bay, Texas: Journal of Sedimentary Petrology, v. 42, p 155-161.

Brown, $\mathrm{R} H, 1963$, Estimating the transmissibility of an artesian aquifer from the specific capacity of a well, in Bental1, Ray, compiler, 1963, Methods of determining permeability, transmissibility, and drawdown: U.S. Geological Survey Water-Supply Paper 1536-I, $341 \mathrm{p}$.

Chen, C. S, 1965, Regional 1ithostratigraphic analysis of Paleocene and Eocene rocks of Florida: Florida Bureau of Geology Bulletin 45, $105 \mathrm{p}$

Davis, S N, and DeWiest, R, I. M, 1966, Hydrogeology: New York, John Wiley 463 p.

Dahrerwend, R E, 1977. Evapotranspiration patterns in Florida: Florida Academy of Sciences, Journal of Florida Scientist, v. 40, no 2, p. 184-192.

Drever, I I., 1982, The geochemistry of natural waters: Englewood Cliffs, N J., Prentice-Hal1, Inc, 388 p.

Farnsworth, R Ko, Thompson, E. S, and Peck, E. Io, 1982, Evaporation atlas for the contiguous 48 United States: US. Department of Commerce, National Oceanic and Atmospheric Administration Technical Report NWS 33, 27 p and 4 sheets.

Ferris, I. Go, Knowles, D. B, Brown, $R, H$, and Stallman, $R$ W., 1962, Theory of aquifer tests: U.S. Gealogical Survey Water-Supply Paper 1536-E, p 69-174.

Florida Department of Natural Resources, 1970, Florida water and related land resourcesSt. Johns River Basin, section 2: Tallahassee, p 180-187.

Hanshaw, B. B, Back, William, and Rubin, Meyer, 1965, Carbonate equilibria and radiocarbon distribution related to ground-water flow in the Floridan limestone aquifer, United States of America: International Association of Scientific Hydrology Symposium, Dubrounik, p. 601-614

Healy, H G, 1975, Potentiometric surface and areas of artesian flow of the Floridan aquifer in Florida, May 1974: Florida Bureau of Geology Map Series 73.

Heath, R C, and Barraclough, I. To, 1954, Interim report on the ground-water resources of Seminole County, Florida: Florida Geological Survey Information Circular 5, 43 p

Lichtler, W. F., 1972, Appraisal of water resources in the East Central Florida Region: Florida Bureau of Geology Report of Investigations 61, $52 \mathrm{p}$ and 1 sheet. 


\section{SELECTED REFERENCES- - Continued}

Lohman, S. W., 1972, Ground-water hydraulics: US Gealogical Survey Professional Paper 708, $70 \mathrm{p}$.

MacNei1, F. S, 1950, Pleistocene shorelines in Florida and Georgia: U.S. Geological Survey Professional Paper 221-F, po 95-107.

Marella, Richard, 1983, Anmul water use survey, 1982: St. Johns River Water Management District, Technical Publication SJ 84-2, $97 \mathrm{p}$

Mason, Brian, 1966, Principles of geochemistry, 73rd ed: New York, John Wiley, 329 p

Matthess, Georg, 1982, The properties of ground water: New York, John Wiley and Sans, Inc, 405 p.

May, S. Ko, Dolan, Robert, and Hayden, B. P., 1983, Erosion of US shorelines: American Geophysical Union, EOS Transactions, v. 64, no. 35, p. 521-522

Morton, Fred I, 1976, Climatological estimates of evapotranspiration: American Society of Civil Engineers, Journal of the Hydraulics Division, p. 275-291.

Opdyke, N. D., Spangler, D. P., Smith, D. L., Jones, D. S., and Lindquist, R. C., 1984, Origin of the epeirogenic uplift of Pliocene-Pleistocene beach ridges in Florida and development of the Florida karst: Geology, v. 12, p. 226-228.

Parkhurst, D. In, Thorstenson, D. C., and Plummer, L N, 1980, HHRERQUE-A computer program for geochemical calculations: U.S Geological Survey Water-Resources Investigations $80-96,210 \mathrm{p}$.

Phelps, G G, 1984, Recharge and discharge areas of the Floridan aquifer in the St. Johns River Water Management District and vicinity, Florida: US Geological Survey WaterResources Investigations Report 82-4058, 1 sheet.

Planert, Michael, and Aucott, W. R, 1985, Water-supply potential of the Floridan aquifer in Osceola, eastern Orange, and southwestern Brevard Counties, Florida: U.S Geological Survey Water-Resources Investigations Report 84-4135, 69 p.

Plummer, L N, 1977, Defining reactions and mass transfer in part of the Floridan aquifer: Water Resources Research, v. 13, no. 5, p. 801-812.

Plummer, L N, Jones, B. F., and Truesdel1, A H, 1978, WATrQF: A Fortran IV version of WATEO, a computer program for calculating chemical equilibrium of natural waters:

US. Geological Survey Water-Resources Investigations 76-13, 26 p

Ross, F. W., and Munch, D. A, 1980, Hydrologic investigation of the potentiometric high centered about the Crescent City Ridge, Putnam County, Florida: St. Johns River Water Management District Technical Report no. 5, 75 p. (Appendix).

Sarver, T. Jo, 1978, Geochemical analysis of selected Eocene carbonate rocks of Peninsular Florida: University of Florida, MS thesis (umpublished), $77 \mathrm{p}$ 


\section{SELECTED REFERENCES--Continued}

Schiner, G R, and Hayes, E. Co, 1981, Potentiometric surface of the Floridan aquifer in the St. Johns River Water Management District and vicinity, Florida, September 1981: U.S. Geological Survey Open-File Report 82-118, 1 sheet.

- 1982, Potentiometric surface of the Floridan aquifer in the St. Johns River Water Management District and vicinity, Florida, September 1982: U.S. Geological Survey Open-Fille Report 83-30, 1 sheet.

Smajstrla, A G, and Clark, G A, 1982a, Potential evapotranspiration probabilities for Daytona Beach, Florida: University of Florida, Institute of Food and Agricultural Sciences Report 82-21, 5 p

- 1982b, Potential evapotranspiration probabilities for Orlando, Florida: University of Florida, Institute of Food and Agricultural Sciences Report 82-22, 5 p

Stephens, J. Co, and Stewart, E. H, 1963, A comparison of procecures for computing evaporation and evapotranspiration: International Association of Scientific Hydrology Committee for Evaporation, Publication 62, p. 123-133.

Stewart, E. H, and Mills, W. C., 1967, Effect of depth to water table and plant density on evapotranspiration rate in southern Florida: American Society of Agricultural Engineers, Transactions, v. 10, no. 6, p. 746-747.

Stewart, I. W., 1980, Areas of natural recharge to the Floridan aquifer in Florida: Florida Bureau of Geology Map Series 98.

Stringfield, V. To, 1934, Ground water in Seminole County, Florida: Florida Geological Survey Report of Investigations 1, $14 \mathrm{p}$.

- 1936. Artesian water in the Florida Peninsula: U.S Geological Survey Water-Supply Paper 773-C. p. 115-195.

- 1966. Artesian water in Tertiary limestone in the southeastern states: U.S. Geological Survey Professional Paper 517, $226 \mathrm{p}$

Stubbs, S A, 1937. A study of the artesian water supply of Seminale County, Florida: Florida Academy of Science Proceedings, v. 2, p. 24-36.

Tibbels, C. H, 1977. Availability of ground water in Seminole County and vicinity, Florida: US Geological Survey Water-Resources Investigations 76-97, $15 \mathrm{p}$ and 4 sheets.

- 1981, Computer simulation of the steady-state flow system of the Tertiary 1imestane (Floridan) aquifer system in east-central Florida: US Geological Survey WaterResources Investigations Open-File Report 81-681, $31 \mathrm{p}$ and 9 sheets.

Todd, D K., 1959, Ground-water hydrology: New York, John Wiley, 336 p.

U.S. National Oceanic and Atmospheric Administration, 1981, Climatological Data, Annul Summary for Florida, 1981, v. 85, no. 13.

1982, Climatological data, annul summary for Florida, 1982, v. 86, no 13. 


\section{SELECTED REFERENCES--Continued}

U.S. Soil Conservation Service, 1966, Soil survey for Seminole County, Florida. 1975, Hydrology national engineering handbock, sec, 4.

Visher, F. No, and Hughes, G. Ho, 1975, The difference between rainfall and potential evaporation in Florida (2d ed): Florida Burean of Geology Map Series 32

Walton, W. C., 1962, Selected analytical methods for well and aquifer evaluation: П1linois State Water Survey Bulletin na 49, 81 p.

- 1970, Ground-water resource evaluation: New York, MoGraw-Hill, Inc, 664 p.

White, W. A, 1958, Some geomorphic features of central Peninsular Florida: Florida Geological Survey Bulletin 41, $92 \mathrm{p}$.

- 1970, The geomorphology of the Florida Peninsula: Florida Geological Survey Bulletin 51, 164 p. 